\title{
Mental
}

PEDAGOGICAL AND PSYCHOLOGICAL PROBLEMS OF THE MODERN SOCIETY: SCIENTIFIC APPROACHES TO THE STUDY AND OVERCOMING PRACTICE

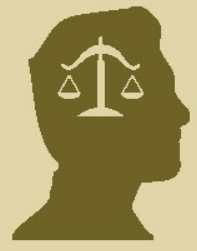

Research articles
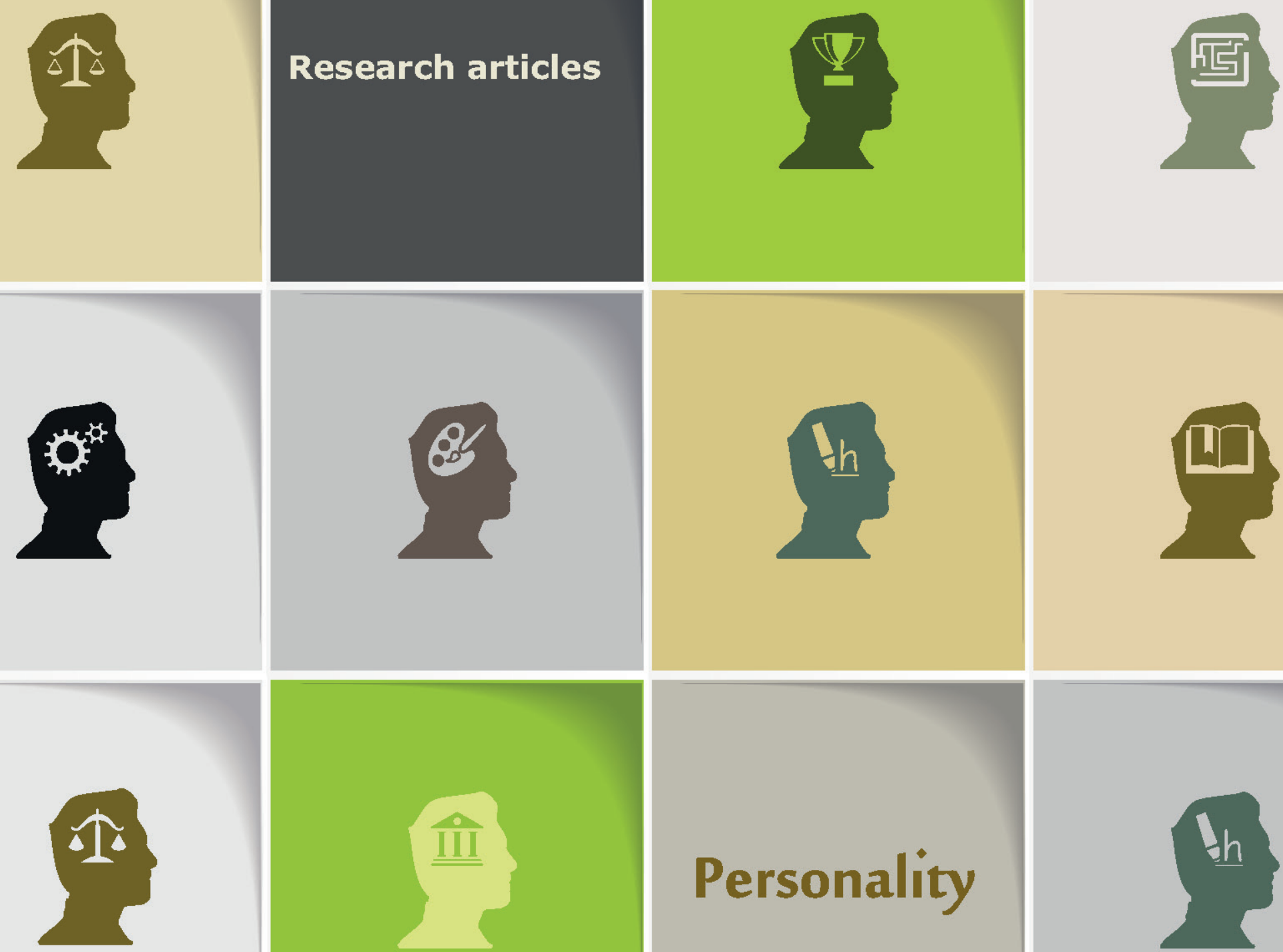

Personality 
PEDAGOGICAL AND PSYCHOLOGICAL PROBLEMS OF THE MODERN SOCIETY: SCIENTIFIC APPROACHES

TO THE STUDY AND OVERCOMING PRACTICES

Research articles

B\&M Publishing

San Francisco, California, USA 
B\&M Publishing

\section{PEDAGOGICAL AND PSYCHOLOGICAL PROBLEMS OF THE MODERN SOCIETY: SCIENTIFIC APPROACHES TO THE STUDY AND OVERCOMING PRACTICES}

Science editor: A. Burkov

Copyright (C) 2014

by Research and Publishing Center "Colloquium"

All rights reserved.

Published by B\&M Publishing.

For permission to use material from this text, please contact the publisher at 2076 -16th Ave., Suite A, San Francisco, California 94116, Tel (415) 6822550
ISBN-10:0991517164

ISBN-13:978-0-9915171-6-9

DOI: http://doi.org/10.15350/L_21_22 


\section{CONTENTS}

O. Aleko

State of displays of primary social experience of children of the senior preschool age in the conditions of modern preschool educational institution M. Ramazanov Modeling of formation process of civil identity of studying youth in an educational field

A. Paramonova

Children's recreation camp as type of additional education of children M. Soboleva

Theoretical and methodological bases of formation of the legal competence of the students of medical institute

L. Aleksandrova \& S. Vatoropina

The study of speech disorders in young children in foster families

Y. Gorneva \& D. Pogonysheva

System and activity approach in training

of it specialists as the basis of realization of FGOS

\section{Y. Gorneva \& D. Pogonysheva}

Application of interactive methods of training, as a condition of increase of motivation of students to discipline studying "Philosophy and education history"

\section{Rubina}

To the question of pedagogical support professional-moral self-actualization of students helping occupations of humanitarian profile, with the transition to the bologna system of higher education

\section{P. Abdulaeva \& Kh. Abdulaeva}

The concept of modernization of promoting formation of information literacy of students of the university of humanities in their future professional activity A. Yevsyukov

Leading concepts of formation of professional and pedagogical competence of future teachers of the highest agrarian educational institutions

\section{A. Yevsyukov}

Technological approach to formation of professional and pedagogical competence of future teachers of the highest agrarian educational institutions G. Zelenova \& T. Vasilyeva The formation of listening skills in the learning process

\section{N. Khacayuk}

Realization of the diagnostic and functional direction in the content of scientific and methodical work of experimental educational institution

\section{N. Krasovska}

Innovative environment as factor of activization innovative components of professional activity of future experts

\section{N. Niyazbaeva}

Didaktogeniya: concept definition

M. Gamzaeva

Application of interactive methods of training, as a condition of increase of motivation of students to discipline studying

"Philosophy and education history"

\section{S. Dagbaeva \& T. Volozhaninova}

The ethnic representations of younger schoolboys 


\title{
STATE OF DISPLAYS OF PRIMARY SOCIAL EXPERIENCE OF CHILDREN OF THE SENIOR PRESCHOOL AGE IN THE CONDITIONS OF MODERN PRESCHOOL EDUCATIONAL INSTITUTION
}

\author{
Oksana Aleko ${ }^{1}$ \\ 1. Post-graduate student, Donbas State Pedagogical University, \\ Slavyansk, Ukraine.
}

Abstract

In article displays of primary social experience of the senior preschool children by means of diagnosing of levels of social experience are analyzed. Some techniques of diagnostic inspection and their results are offered.

Keywords: social experience, socialization to personality, child of preschool age, preschool educational institution, family.

На современном этапе развития дошкольного образования особое внимание акцентируется на воспитании социально зрелой, успешной, развитой и уверенной мичности. Серьезные трансформации, происходящие в современном обществе, обуславливают необходимость учета их влияния на процесс социализации Аичности дошкольника. Особую актуальность в настоящее время приобретает исследование процесса социального становления и формирования социального опыта ребенка.

В последнее время в Украине усиливается внимание к проблемам детей дошкольного возраста и к проблемам ведущего института социализации мичности ребенка - дошкольному образовательному учреждению. Об этом свидетельствует появмение новых нормативно-правовых документов: Государственной цемевой социальной программы развития дошкольного образования на период до 2017 года, Национальной программы воспитания детей и ученической молодежи в Украине, Закона „О дошкольном образовании", обновценного Базового компонента дошкольного образования. Проблема формирования первичного социального опыта 
ребенка в дошкольном учреждении и семье приобретает особенную значимость.

Сегодня наблюдается повышенное внимание ученых к осмыслению, правильной формулировке и решению педагогических проблем, которые непосредственно касаются социализации, социального становления детей и молодежи. Эти вопросы затронуты в исследованиях И. Беха, Н. Головановой, П. Горностая, И. Зверевой, И. Ермакова, А. Капской, $\Lambda$ Коваль, Н. Аавриченко, Г.Аактионовой, $\Lambda$. Мардахаева, В. Москаленко, А. Мудрика, С. Савченко, В. Серикова, С. Харченко и др.

Присоединяясь к ведущим исследователям, мы считаем, что основой социализации является социальный опыт ребенка, усваивая который, он осуществляет саморазвитие и становится социально компетентным.

Целью статьи является: анализ состояния проявлений первичного социального опыта старших дошкоцьников с помощью диагностирования уровней социальной опытности в условиях дошкольного учреждения.

Мы поддерживаем профессора Н. Голованову, которая в своем исследовании обращает внимание на то, что в детской среде, особенно в крупных городах, активно проявцяется социальное неравенство: большая разница в статусах семей, разное экономическое положение. Важнейшим средством социальной защиты детей, выравнивания их возможностей дмя социального старта может стать комлектив $[1,236]$. В нашем случае - это комлектив дошкольного учреждения, дошкольной группы детского сада.

Особенностью формирования социального опыта дошкольника является то, что оно не ограничивается определенными формами работы, местом в режиме дня, диительностью во времени. Ребенок добывает социальный опыт постоянно, а воспитатель должен постоянно насыщать этот опыт позитивным содержанием. Вся атмосфера детского сада, поведение взрослых, общение, совместная деятельность детей - должны способствовать обогащению благоприятного социального опыта.

Формирование эффективного первичного социального опыта старших дошкольников возможно при условии постоянного участия родителей в педагогическом процессе дошкольного учреждения, чего можно достичь путем педагогического просвеще- 
ния семьи и осуществления партнерства педагогического комлектива и семей воспитанников.

Основными задачами констатирующего этапа исследования явАяются:

1. Определить критерии, показатели и уровни социальной опытности детей старшего дошкольного возраста.

2. Выявить состояние готовности воспитателей и родителей к формированию первичного социального опыта детей в процессе педагогического взаимодействия.

Программа констатирующего эксперимента вк^ючала три направцения:

I направление - работа с детьми.

1. Диагностирование уровней социальной опытности детей.

2. Анализ состояния проявцений социального опыта дошкоцьников в разных видах деятемьности.

II направление - работа с воспитателями дошкольных учреждений.

1. Изучение представцений воспитателей о задачах и содержании формирования первичного социального опыта старших дошкольников.

2. Изучение опыта работы с родителями относительно формирования первичного социального опыта у детей.

III направление - работа с родителями.

1. Изучение представцений родителей о роли формирования первичного социального опыта у детей.

2. Опредемение готовности родителей к совместной деятемьности с воспитателями по формированию социального опыта у дошкомьников.

В границах данной статьи мы остановимся на первом направцении констатирующего этапа эксперимента.

Разрабатывая методику эксперимента, мы исходики из того, что социализация - это процесс овладения ребенком социального опыта, принятыми в обществе нормами, ценностями, модемями поведения и творческая их репрезентация на основе рефлексивного выбора по целесообразности и необходимости. Мера этого овладения, рефцексивного выбора и репрезентации рассматривамась нами как свидетельство наличия у ребенка определенного уровня социальной опытности. 
Опытность (по словарю Т. Ефремовой) - это обладание опытом, практическими знаниями в Аюбой области [3].

Значение слова опытность по словарю Д. Ушакова толкуется следующим образом, - это обладание опытом, практическое знание, полученное из собственного опыта [4].

Поэтому, опираясь на вышеуказанные определения, мы обозначаем соииальную опытность дошкольника, как обладание ребенком опытом социально принятой в обществе модели поведения, определенных социальных норм и ценностей, полученных из собственного опыта.

В работе мы использовали комплекс взаимосвязанных методов педагогической диагностики, который включал следующие их разновидности: опрос, анкетирование, беседы, метод рисуночных тестов, тематическое рисование, метод незаконченных предложений, решение проблемных ситуаций, целенаправленные педагогические наблюдения, статистические методы обработки информации.

Дия выявления уровня сформированности представлений детей о социальных нормах поведения мы разработали следующий опросник:

1. О каком человеке мы можем сказать, что он добрый или зАой?

2. Что такое правима поведения, какие ты знаешь правила поведения?

3. Дия чего существуют правица поведения?

4. Как нужно здороваться (какими словами) утром, в обед, вечером?

5. Как ты думаешь, в твоей группе дети хорошие или плохие? Почему?

6. Можешь $и$ ты подарить другу игрушку навсегда? Как ты считаешь, какое настроение у него будет, если ты подаришь ему игрушку?

7. Как ты чувствуешь себя, когда твоего друга наказывают, обижают?

8. Как ты чувствуешь себя, когда воспитательница хвалит тебя за что-то, а как когда хвалит твоего товарища?

9. Смог бы ты помочь своему товарищу, если у него что-то не получается?

10. Что бы ты делал, если бы остался один на Земле? 
11. Кем быть мучше - ребенком или взрослым? Почему?

12. Чего бы ты пожелал, если бы волшебник предложил выполнить Аюбые твои три желания?

Результаты диагностики дали возможность констатировать, что в целом для детей старшего дошкольного возраста характерно поверхностное знание социальных норм и правил поведения на вербальном уровне. Полученные данные мы проверяли в реальной практической деятельности; исследовали, каким образом знание социальных норм поведения дошкольники используют в повседневной жизни. Мы наблюдали за поведением детей в разных видах деятельности (игровой, трудовой, изобразительной, музыкальной, театрализованной, самостоятельной и т.д.), оценивали его в соответствии с составленной программой наблюдения и определяли уровень сформированности социальных норм поведения.

В результате обследования детей мы получили следующие результаты: $22 \%$ дошкольников имеют высокий уровень сформированности социальных норм поведения. Они правильно и громко здоровались и прощались, обращаясь к детям всей группы; употребляли „волшебные” слова; с доверием обращались к воспитателям и детям с разными просьбами, предложениями; говорили спокойно, доброжелательно. Эти дети владели культурой диалога, не перебивали разговоров старших и детей, умели слушать других, в конфликтных ситуациях спокойно отходили в сторону; с готовностью предлагали помощь и с благодарностью принимали ее от взрослых и детей.

$52 \%$ респондентов мы отнесли к среднему уровню сформированности социальных норм поведения. Они громко здоровались и прощались только с воспитателем; иногда обращались к воспитателям и детям с разными предложениями; подчас использовали командный тон; эти дети благодарили самостоятельно без напоминания, в отдельных случаях благодарность выражалась невербально. Культуры диалога придерживались в отдельныхслучаях, нередко перебивали, Аюбили говорить сами и не умели слушать других, при этом стремились приказывать другим; в конфмиктных ситуациях чаще с обидой или змостью отходили в сторону; помогали с желанием, но по просьбе взрослого; от помощи детей чаще всего отказывались. 
26 \% старших дошкольников мы отнесли к низкому уровню сформированности социальных норм поведения. Эти дети не проявили умения здороваться и прощаться без напоминания взрослого, а некоторые отмалчивались даже при напоминании; не умели благодарить; не придерживались культуры диалога, зачастую перебивали; не умели слушать других. В конфликтных ситуациях переходили к асоциальным формам поведения (отбирали, дрались, кричали), не изъявляли желания помочь и от помощи других детей отказывались.

Современные исследователи единодушны во мнении, что успешность социализации зависит от самооценки мичности. Самооценка - это процесс, который непосредственно регулирует соблюдение норм морали, обеспечивает адекватность осознания своего „Я-реального”.

В нашем исследовании мы использовали игру „Ступеньки”, которая, на наш взгляд, явцяется наиболее удачной для старших дошкольников.

\section{Методика „Ступеньки”.}

Цемь: диагностика уровня самооценки детей дошкольного возраста.

Инструкция: Ребенку предиагается рассмотреть 5 ступенек разного цвета и фигурка персонажа (мальчика или девочки). Экспериментатор говорит: „Это как будто ты. Хорошо? А вот ступеньки, они разного цвета. Поставь, пожалуйста, себя на одну из них. Но учти, что вот эта, самая низкая - черная ступенька - дмя детей, которые ведут себя всегда плохо, невежливо. Коричневая вторая ступенька - для детей, которые иногда ведут себя вежливо, но чаще нет. Третья - синяя ступенька - принимает детей, которые ведут себя хорошо, но не всегда. Четвертая - желтая ступенька - принимает детей, которые ведут себя еще мучше; а пятая красного цвета, самая высокая ступенька - для детей, которые всегда поступают хорошо и совершают только добрые поступки! Выбери ту ступеньку, на которую сможешь поставить себя".

Методический комментарий: Результаты эксперимента фиксировались в протоколе. Принято считать, что самооценка ребенка соответствует тому уровню, на который он себе поставил: 1-2 ступеньки - низкий, 3 - средний, 4-5 - высокий.

Полученные в результате диагностики результаты показали, что адекватная самооценка присуща Аишь $25 \%$ дошкольников. 
$27 \%$ детей характеризуются заниженной самооценкой, а $48 \%$ завышенной. У большинства детей самооценка имеет некритический характер, не отображает моральную ценность их поведения.

Важную, зачастую ведущую, роль в формировании социального опыта дошкольника играет семья. В экспериментальном исследовании мы использовали модифицированные рисуночные тесты Р. Жимя „Прогулка по месу”, „В кинотеатре” и тематическое рисование „Моя семья”. Предлагаем в качестве примера характеристику рисуночного теста „Прогумка по месу”.

Цемь: выяснить отношение детей к родителям, родным, ощущения детей в роли ребенка.

Инструкция: детям раздали мисточки бумаги, в разных местах которых были изображены деревья, у некоторых из них изображены чцены семьи: мама, папа, братик (сестренка). Детям предлагалось представить, что они гуляют со своими родными по месу, и обозначить того из них крестиком, с кем бы они хотели быть рядом.

Анализ рисуночных тестов и тематического рисования показал, что около трети детей чувствуют себя отдаленно и обособменно от членов семьи. Учитывая первостепенную роль семьи в социализации мичности, можно предугадать, что группа детей, которая не ощущает эмоциональной близости с членами семьи, испытывает определенные трудности в этом процессе.

Подводя итоги можно констатировать, что для большинства старших дошкольников (59 \%) характерным является средний уровень социальной опытности. Эти дети ощущают трудности в соотношении поведенческой деятельности с социальными нормами, в установлении и развитии конструктивных отношений с ровесниками, порою не имеют эмоционально близких отношений с чценами семьи (чувствуют себя одинокими или в большей степени принимаются бабушкой и дедушкой, а не родителями).

Значительное количество детей (27 \%) имеет низкий уровень социальной опытности. Они трудно принимаются комлективом ровесников, эмоциональная близость в большей мере проявляется относительно одного из чценов семьи. Сравнительно с детьми предыдущей группы, имеющиеся осложнения имеют более глубокий и более стабильный характер.

Дети, которых мы отнесли к высокому уровню социальной опытности (14\%), составцяют по численности наименьшую груп- 
пу. Определенных выразительных трудностей в исследуемом направлении выявлено не было. Семьи отличаются сплоченностью, демократичностью отношений; ребенок настроен на эмоциональную близость с обоими родителями.

Перспективы дальнейших поисков исследования мы видим в разработке модели формирования первичного социального опыта детей в процессе взаимодействия дошкольного учреждения и семьи, а также в усовершенствовании оптимальных форм этого взаимодействия.

\section{References:}

1. Голованова Н.Ф. Социализация и воспитание ребенка. СПб.: Речь, 2004. - 272 с.

2. Дети и социум: особенности социализации детей дошкоцьного и мцадшего шкоцьного возраста: [монография А.М. Богуш, М.О. Варяница, Н.В. Гавриш и др.]; науч. ред. А.М. Богуш; за ред. Н.В. Гавриш. - Ауганск, 2006. - 368 с.

3. Ефремова Т.Ф. Новый словарь русского языка. Толковословообразовательный. - М.: Дрофа, Русский язык, 2000. - 1233 с.

4. Толковый словарь русского языка: В 4 т./Под ред. Д.Н. Ушакова. - Т. 1. - М.: ООО “Издательство Астрель», 2000. 848 c. 


\title{
MODELING OF FORMATION PROCESS OF CIVIL IDENTITY OF STUDYING YOUTH IN AN EDUCATIONAL FIELD
}

\author{
Marat Ramazanov 1
}

1. Postgraduate student, Center of Advanced Economic Research Academy of Sciences of the Republic of Tatarstan, Russia.

\section{Abstract}

Formation of civil identity of the personality in the conditions of an educational field - one of key aspects of researches of modern education sociology. In author's research an attempt of structuring process of civil identity formation of pupils and creation of its functionality empirical model in the conditions of cadet schools is made.

Keywords: civil identity of the personality, cadet school, system of cadet education, social institute.

Успешность жизненной стратегии мичности в контексте современного общества во многом зависит от ее гражданской активности, которая обусловлена гражданской идентичностью. Гражданская активность Аичности, в свою очередь, способствует наиболее полноценной ее самореализации во благо общества и государства, в чем и состоит социальный аспект исследуемой проблемы.

Процесс формирования мичности на этапе взросления и первичной социализации происходит, в большей степени, в образовательном поле. В этой связи, создание эффективной модели управления данным процессом является целевым ориентиром в системе учреждений образования как жизненной среды учащейся молодежи.

Контекстуально интерпретируя понятие, выстроим собственную (авторскую) модель гражданской идентичности кичности. Под ней мы понимаем совокупность ментальных ценностей и установок поведения цичности, преломленных через различные идентификационные поля: экономическое, политическое, право- 
вое, национально-культурное и выражаемых через различные ви-

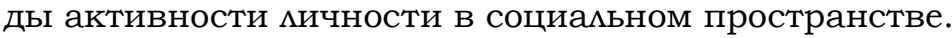

В разрезе основных результатов исследований можно сдемать следующие выводы.

Если бы Вам представилась возможность уехать за рубеж, хотели бы Вы уехать? Доля ответивших, \%

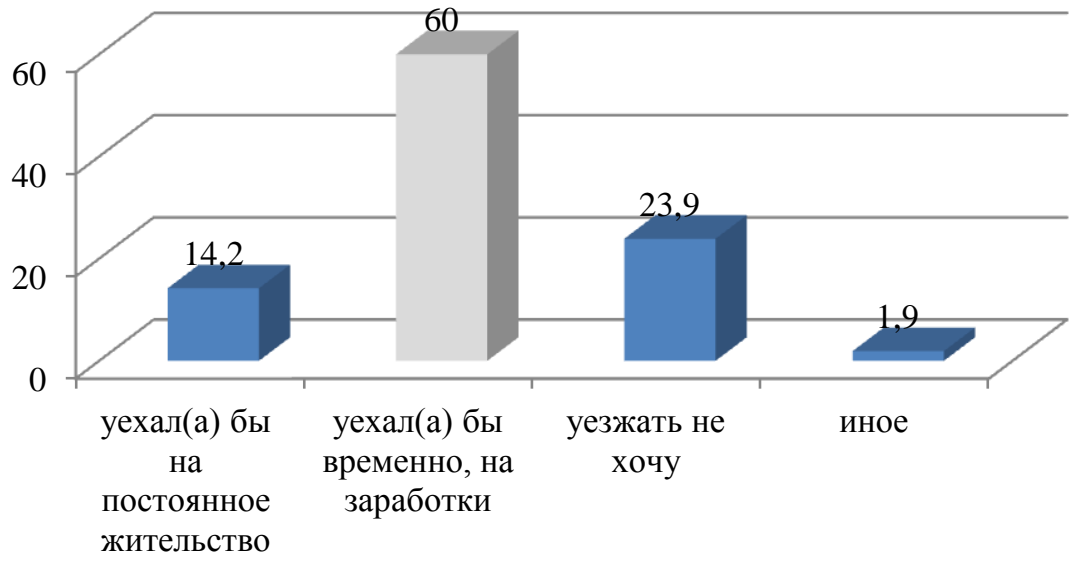

Рис. 1. Эмпирический критерий: мояльность Родине

Патриотизм как явление выражается, в том числе, через приверженность Родине, желании жить и трудиться на ее земле. По результатам исследования, большинство учащихся кадет не выражают такой приверженности, стремясь покинуть страну $\Lambda и-$ бо временно, мибо постоянно. Так, почти две трети кадет хотели бы уехать за рубеж временно, на заработки (60\%), 14\% выразими желание уехать из России на постоянное место жительства. Только четверть опрошенных ответила, что не желает уезжать за рубеж (см. рис.1).

В ходе проведенных исследований выстроена эмпирическая модемь процесса формирования гражданской идентичности учащейся молодежи. Проведенные исследования, в целом, подтвердими поставменную гипотезу о том, что действующая в образовательном поле учебных заведений модель формирования гражданской идентичности учащейся молодежи не обладает достаточной функциональностью, поскольку ее воздействие проявцяет- 
ся односторонне, фрагментарно; соответственно, она нуждается в оптимизации, корректировании.

\section{Таблица 1}

Гражданская активность учащихся: участие в разАичных мероприятиях

\begin{tabular}{|l|c|}
\hline $\begin{array}{c}\text { В каких внеклассных, внеурочных мероприятиях } \\
\text { школьной жизни кадетов } \\
\text { Вы принимаете участие? }\end{array}$ & $\begin{array}{c}\text { Доля } \\
\text { ответивших, } \\
\%\end{array}$ \\
\hline спортивные, военно-спортивные мероприятия & 60,9 \\
\hline творческие вечера, конкурсы самодеятемьности & 16,7 \\
\hline участие в шкомьном самоуправ ении & 12,2 \\
\hline другая общественная работа & 6,4 \\
\hline участие в волонтерском движении & 4,5 \\
\hline иное & 1,3 \\
\hline $\begin{array}{l}\text { во внеурочных, внеклассных мероприятиях не } \\
\text { участвую }\end{array}$ & 20,5 \\
\hline Все опрошенные & 100,0 \\
\hline
\end{tabular}

Исследования выявили, что наиболее системная и планомерная работа среди кадет по формированию их гражданской идентичности ведется в аспектах военно-патриотического компонента, трудового сознания. Остальные компоненты - экологическая, национально-культурная, историческая, политикоправовая - развиты слабо, воздействие на их формирования со стороны образовательного поля проявцяется, скорее, не системно.

Гражданская активность учащихся как деятельностная компонента гражданской идентичности развита слабо. Из таблицы 1 видно, что основными мероприятиями, в которых достаточно активно участвуют учащиеся кадеты, явцяются мероприятия спортивной и военно-спортивной направценности (61\%). Вовлеченность кадет в другие мероприятия значитемьно ниже.

Формируемая в условиях образовательного поля модець патриотизма и гражданственности учащихся кадет характеризуется преобладанием "созерцательного патриотизма", то есть ожиданий, стремлением "принимать" а не "отдавать" стране, государству, обществу и своему народу. Патриотизм, в основном, не ассоциируется у обучаемых кадет с необходимостью приносить пользу Родине, а если и ассоциируется, то на уровне абстракций ("Аюбить вообще, уважать вообще»), не преломляясь через кон- 
кретные эмпирические индикаторы, и прежде всего, через действие, участие.

Понятие же «быть гражданином своей страны" трактуется учащимися чаще через индикатор “знания своих прав" и слабо коррелирует в сознании опрошенных с могичным продолжением "знанием и несением своих обязанностей". При ответе на данный вопрос наиболее распространенными являются формулировки "проживать только в своей стране, работать в ней", "быть патрио-

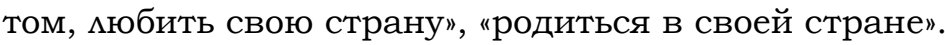

В результате у учащихся формируется «пассивносозерцательное" гражданское и патриотическое сознание, направленное на восприятие Родины, страны, общества, государства на абстрактно-чувственном уровне, без активизации деятемьностной компоненты, предполагающей активное участие в судьбе Отечества.

В этой связи стоит подчеркнуть, скорее, пассивную роль самих педагогов как организаторов образовательного процесса. Педагоги, равно как и другие субъекты образования (общественные организации, гражданские активисты фактически слабо вовлечены в организацию и проведение различных мероприятий по формированию гражданской идентичности мичности учащихся, что формирует низкий уровень информационнокоммуникативного поля образовательного пространства.

В целях оптимизации модеми управления процессом формирования гражданской идентичности учащейся молодежи в образовательном поле, полагаем, необходимы комплексные меры, вк^ючающие кадрово-организационное, научно-методическое, инновационное, информационное обеспечение образовательного процесса. В целом, оптимизация модеми управления домжна быть направцена, прежде всего, на активизацию субъект-субъектных отношений в системе Педагог-Учащийся, повышение субъектного начала обучаемых как предпосылки развития их гражданской активности.

\section{Примечания}

Исследование проведено автором среди учащихся кадетских классов и кадетских школ (шкоц-интернатов) Республики Татарстан. Опрошены 741 учащихся по репрезентативной стратифицированной выборке методом анкетного опроса. Произведен анкетный опрос педагогов кадетских шкоц (выборка 132 чем.). 
Период обследования - сентябрь-ноябрь 2012г. Автором также проведен экспертный опрос среди руководителей кадетских школ, представителей ведомств (ГИБДД, Министерство по демам молодежи, спорту и туризму РТ), общественных организаций. 


\title{
CHILDREN'S RECREATION CAMP AS TYPE OF ADDITIONAL EDUCATION OF CHILDREN
}

\author{
Anna Paramonova ${ }^{1}$ \\ 1. PhD, Institute of a development of education, Russia.
}

\begin{abstract}
The article considers the children's recreation camp as a special type of additional education, defines the conditions and principles of organization of teaching process in the camp, his features.
\end{abstract}

Keywords: children's health camp, socialization, the additional education.

Происходившие в Российском государстве на рубеже XXXXI вв. политические и социально-экономические перемены оказали серьезное влияние на все стороны современного состояния общества. Они привели к изменению ценностных ориентаций прежде всего подростков и молодежи, к деформированию у них существовавших ранее убеждений и взглядов, вытеснению духовных потребностей, ослаблению воспитательной функции семьи, самоустранению большей части родителей от воспитания своих детей. Только смещение приоритетов в сторону воспитания подрастающего поколения способно преодолеть многие негативные тенденции, осложняющие жизнь общества. Законопослушность, правопорядок, доверие, развитие экономики и социальной сферы, качество труда и общественных отношений - все это непосредственно зависит от принятия гражданином России общенациональных и общечеловеческих ценностей и следования им в Аичной и общественной жизни.

K специальным социальным институтам относится не только школа, но и профессиональные учебные заведения, молодежные организации и объединения, которые на сегодняшний день играют огромную роль в социализации подрастающего поколения. Одним из таких видов дополнительного образования на сегодняшний день явцяется детский метний магерь. 
Современные тенденции школьного образования указывают на то, что школа только определила для себя идеологические и ценностные рамки, возвращаясь на путь приоритета воспитания. Однако этот процесс, как и мюбая педагогическая инициатива длителен по времени, тогда как результаты кризисного периода смены идеологий в нашей стране мы наблюдаем до сих пор. Кружки, спортивные секции и другие учреждения дополнительного образования закрываются из-за отсутствия финансирования, и дети предоставлены сами себе, негативному влиянию улицы, телевидения и компьютерных игр. Однако сегодня продомжают работу детские оздоровительные магеря, организаторы которых в современных условиях занимаются поиском и созданием эффективных педагогических и организационных условий пребывания воспитанников.

Аетний оздоровительный магерь - особый тип дополнительного образования, основным предметом деятельности которого является свободное время ребенка [3]. Эту форму организации досуга детей во время каникуи можно назвать традиционной. По данным Г. Онищенко на 2012 од за время метней оздоровительной кампании в России отдохнуло более 4,5 млн. детей [5]. На сегодняшний день детские метние магеря остаются самым популярным видом детского туризма в России. Это связано еще и с тем, что в России, как ни в одной другой стране мира, именно детский туризм носит социальный статус, что означает полное или частичное финансирование данного вида деятельности за счет бюджетных средств государства.

Несмотря на то, что зачастую детские магеря напрямую связаны с деятельностью муниципальных методических служб, управлениями образованием, образовательными учреждениями города, организаторы детского досуга вынуждены идти на уступки современным понятиям об отдыхе и развлечениях. И если спортивная (оздоровительная) составцяющая по-прежнему является актуальной для большинства родителей и их детей, то воспитательная сфера зачастую представлена псевдопедагогическим наполнением. То же можно сказать и педагогических кадрах, которые осуществляют "воспитательную" работу в детских магерях. Зачастую это и студенты первых курсов педагогических вузов, а бывает и так, что воспитатель или вожатый вообще не имеют педагогического образования или опыта работы с детьми. 
Однако российская традиция организации детского метнего отдыха берет свое начало в "пионерских" магерях [2]. Нельзя оставить без внимания тот факт, что советские пионерские магеря были могическим продолжением пионерского и комсомольского движения. Фактически такой магерь был продолжением отрядной деятельности в метний период с упором на спортивное и военнопатриотическое воспитание.

С самого начала возникновения пионерской организации $\mathrm{K}$ вожатым предъявлялись повышенные требования. Вожатые должны были «знать основы методики и практики работы пионерского отряда, историю детского движения, возрастные особенности детей и подростков школьного возраста во главе отрядов должны стоять передовые комсомольцы, знакомые с основами педагогики, Аюбящие физкультуру, знающие митературу, технику и своим мичным примером показывающие образцы поведения для детей" [7]. Основанием этой системы была идеология. Пионерские магеря в советское время были предназначены не только для целого комплекса спортивных мероприятий, но и для вполне целенаправценной воспитательной работы. Так же как и во время учебы, все воспитанники магеря формировались в пионерские дружины и отряды, принимали участие в кружках и играх. Часто пионеры оказывали помощь жителям села и вели просветительскую работу среди сельских детей. Жизнь и развитие магеря отображали жизнь советской страны.

Таким образом, воспитательная системы в пионерских магерях основывалась на опредеменных установценных нормах, ценностях, что позволяло привести воспитательный процесс в магере в строгую систему, которая являмась цогическим продолжением воспитательного процесса во время учебного года.

Сегодня мы можем говорить, что педагогическая мысль последних мет пришла к выводу о безусловной необходимости включения духовно-нравственной составляющей в учебновоспитательный процесс на всех уровнях образования. Появимась "Концепция духовно-нравственного развития и воспитания Аичности гражданина России в сфере общего образования", в которой сформулированы не только основные "вызовы" современному обществу, но и система базовых национальных ценностей, современный национальный воспитательный идеал, цель и задачи ду- 
ховно-нравственного развития и воспитания подрастающего покомения.

Детский метний оздоровитемьный магерь, как вид дополнительного образования детей сегодня так же осуществляет социально-педагогическую деятельность, которая имеет свою историческую и научно-методическую основу. Педагогический процесс в детском магере опирается на общие законы и закономерности психоцогии, социологии и педагогической науки, а так же теорию и практику социальной работы. Это связано с тем, что воспитательная работа в магере, как и в мюбом образовательном учреждении, связана в первую очередь с социализацией мичности ребенка, как «процесса развития человека во взаимодействии с окружающим миром" (А.В. Мудрик). Социализация ребенка - как ююбой кумьтурный феномен - процесс двухсторонний. С одной стороны, входя в социальную среду, ребенок усваивает опредеменный опыт покомений и современного общества, а с другой сам становится активным субъектом социальных отношений [6]. Социальное воспитание - одна из основных задач детского магеря. Понятие это очень широкое и включает в себя несколько направлений: охрана здоровья, гуманизация общественных отношений, приобщение к нравственным ценностям, приобщение к труду, эстетическое развитие и т.д. В детском магере это становится возможным благодаря тому, что, выключаясь из привычной жизни, отрываясь от опеки родителей, учась обходится без привычной обстановки и вещей, ребенок вкАючается в активный процесс коммуникативной, трудовой, познавательной, физической, эстетической деятельности, получает возможность "примерить" на себя различные социальные роли (через игру, участие в мероприятиях магеря, разцичных тренингах, конкурсах, поручениях), получить новую информацию о мире, пообщаться с новыми мюдьми. Отдемьно стоит отметить, что находясь в магере, ребенок вкцючен в этот воспитательный процесс круглосуточно, что позволяет добиться уникальных условий социализации, главными характеристиками которых является требование самостоятельности, постоянное обращение к жизненному опыту детей, активность, коммуникабельность и т.д.

Таким образом, социально-педагогическую деятельность магеря необходимо рассматривать как специально организованный процесс создания в магере условий психолого-педагогической 
поддержки и социальной защиты ребенка с целью эффективной его социализации (Ю.Н. Таран).

Исследователи (А.В. Волков, И.И. Фришман и др.) выделяют следующие функции педагогической деятемьности в детском магере:

- воспитательная функция (развитие у ребенка нравственных качеств, навыков межличностных отношений, эстетическое развитие, приобщение к общечеловеческим ценностям);

- функция просвещения (передача социально важной информации воспитанникам: этическое, правовое, бытовое просвещение);

- компенсирующая (или корректирующая) функция (нейтрамизация факторов, негативно вмияющих на развитие и становле-

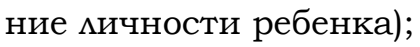

- реабилитационная функция (восстановцение физических и душевных сим ребенка);

- социально-правовая функция (работа в магере ведется в соответствии с требования по защите прав ребенка). [1]

Помимо общепедагогических принципов деятельности детского магеря (природосообразность, гуманистическая направленность и т.д.) существуют группы принципов социальнопедагогической работы в магере:

1. Методологические (принцип развития, неразрывной связи индивида и его социамьной среды, детерминизма, системности и т.д);

2. Организационные принципы (компетентность и профессионализм кадров, принципы управления);

3. Психолого-педагогические принципы (принцип независимости воспитания, принцип диалогичности, принцип опоры на

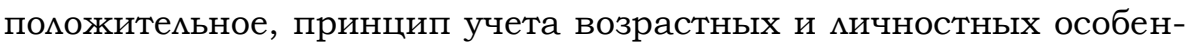
ностей).

4. Специальные принципы работы в условиях детского магеря (принцип безопасности жизни и здоровья детей, принцип конфиденциальности проблем и конфмиктов, принцип клиентоцентризма, принцип максимахизации ресурсов). [8]

Отметим так же, что опираясь на принцип клиентоцентризма, организаторы детского цетнего магеря ориентированы, прежде всего, на обеспечение воспитанникам полноценного отдыха и оздоровления. Однако понятие "полноценный отдых" 
весьма абстрактно, так как запрос спектра видов деятельности в магере будет зависеть от контингента родитемей и детей. Это в свою очередь приводит к тому, что, несмотря на определенные традиции каждого магеря, формы, методы и средства работы с детьми будут варьироваться от смены к смене и от года к году.

В таких условиях эффективность воспитательного процесса в ДО $\Lambda$ может быть обеспечена педагогическим комлективом: «Ни один воспитатель не имеет права действовать в одиночку, на собственный страх и риск и на свою собственную ответственность. Должен быть комлектив воспитателей, и там, где воспитатели не соединены в колмектив и комлектив не имеет единого плана работы, единого тона, единого точного подхода к ребенку, там не может быть никакого воспитательного процесса" [4]

По оценке специалистов (М.Б. Коваль, Т.А. Юзефавичус и др.), педагогический комлектив магеря - это комлектив мюдей размичных профессий и жизненного опыта. В кучшем случае - это школьные педагоги, которые зачастую переносят формы и методы работы в классе на отрядную жизнь. В данном случае важна роль руководителя, который сумел бы грамотно организовать работу коммектива, чтобы Аюди различных профессий и характеров могли дополнять друг друга в общем деме [9].

Отдельно хотелось бы выделить процесс мониторинга социально-педагогической деятельности детского магеря. Дия того чтобы поддерживать эффективность воспитательной работы в магере, необходимо постоянно анализировать процесс и результаты такой работы. Мониторинг эффективности воспитательного процесса должен осуществляться как непосредственно в процессе, так и на промежуточных этапах: в середине и в конце смены, по окончании метней кампании и т.д. Это дает возможность в первую очередь определить эффективные формы, методы и средства работы с детьми, отметать бесполезные, показавшие свою педагогическую неуместность, определить наиболее благоприятные организационно-педагогические условия работы, таким образом, представив научное обоснование эффективности своей деятельности.

Обращаясь $к$ организационно-педагогическим условиям деятельности детского магеря необходимо условно разграничить два их типа: инвариативные (от мат. invarians, invariantis - неизменяющийся) и вариативные. 
K инвариативным условиям мы относим такие условия, которые необходимо учитывать как данность, при выстраивании последующей педагогической деятельности. К ним мы относим, например, временный характер детского объединения в магере, временные сроки пребывания детей в магере (диительность смены), изменение бытового контекста жизнедеятельности детей в магере, природно-кмиматическая база.

$\mathrm{K}$ вариативным условиям относятся такие условия, которые организаторы магеря и его педагогический комлектив могут корректировать мибо создавать на основании педагогической целесообразности. К таким условиям мы относим разнообразие форм и видов деятельности, методы и средства воспитательной работы, применение мичностно-ориентированного подхода, наличие определенных правиц, Устава магеря, режимных моментов, а так же идеологическую основу воспитательной работы в магере.

Особенностью воспитательной среды мюбого магеря в первую очередь становиться тот факт, что дети, «вырванные» из привычных условий домашней жизни с родителями получают возможность самостоятельно выстраивать отношения в комлективе, принимать условия человеческого общежития, использовать свой жизненный опыт в решении спонтанных задач, а педагоги, в свою очередь, имеют возможность ежедневно предлагать детям совершенно разцичные направления деятельности, большой объем информации, развивать коммуникативные, трудовые, познавательные навыки воспитанников. При этом необходимо отметить, что сам процесс воспитания в детском магере носит латентный характер - все виды деятельности связаны с игрой, соревнованием, культурно-массовыми мероприятиями.

Говоря об особенностях организации воспитательной работы в магере в целом мы уже отмечали, что детский оздоровитель-

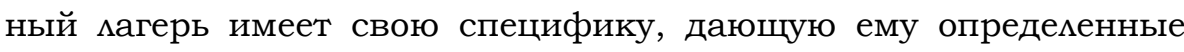
преимущества перед другими учреждениями дополнительного образования. Прежде всего они в том, что обстановка сильно отмичается от привычной домашней. Это выражается в совместном проживании детей: "Познание способа совместного проживания в группе сверстников обладает свойством обучения детей в комлективе, которое редко где можно найти" (А.Б. Бом ). Именно здесь воспитанники более тесно взаимодействуют со своими взрослыми наставниками, между ними быстрее возникает "зона доверия", 
приобщаются к здоровому и безопасному образу жизни - в естественных условиях социальной и природной среды. Дети активно общаются с природой, что способствует укреплению их здоровья и повышению уровня экологической культуры. Отдых, развлечения и всевозможные хобби детей дают им возможность восстановить свои физические и душевные силы, заняться интересным делом. Все это помогает развить новые навыки, раскрыть потенциал своей мичности. Таким образом:

-Детские магеря являются частью социальной среды, в которой дети реализуют свои возможности, потребности в индивидуальной, физической и социальной компенсации;

-В основе деятельности детского магеря межат принципы массовости и общедоступности мероприятий по интересам; развития творчества и самодеятельности, социально значимой направленности деятельности; единства оздоровительной и воспитательной работы с детьми; взаимосвязи с семьей и социальной средой;

-Детские магеря сегодня обладают достаточной методической и материальной базой, чтобы предложить воспитанникам развивающую деятельность разцичной направленности: творческой, интемлектуальной, спортивной и др.;

-Детские магеря характеризуют предметно-практическую деятельность, конкретные жизненные ситуации, которые помогают познать ребенка, выстроить отношения между детьми, детьми и взрослыми.

При правильно организованной деятельности детский магерь располагает благоприятной атмосферой дмя самопознания и самовоспитания, что обусловлено рядом особенностей. В условиях магеря могут быть организованы все приоритетные дмя подростка виды деятельности (коммуникативная, спортивная, трудовая, познавательная, эстетическая, художественно-творческая, образовательная и т.п.). Взаимодействие детей в магере носит нетрадиционный характер по содержанию и форме включения их в те или иные сферы деятельности, что способствует проявлению инициативы и субъектной активности. Каждый воспитанник поцучает возможность рефмексии, находясь в процессе общения со взрослыми и сверстниками, решая ту или иную проблему. 
Условия в магере таковы, что каждый ребенок ощущает сопричастность к решению задач, стоящих перед комлективом. Развитие самоуправцения помогает почувствовать всю сложность социальных отношений, способствует формированию социальной активности, развитию мидерства.

Через свое участие в решении проблем отряда, магеря дети вырабатывают у себя качества, необходимые дмя преодомения сложностей социальной жизни.

\section{References:}

1. Волков А.В., Фришман И.И. Внимание, каникулы! Методическое пособие. - М.: ЦГА. 2005. - 128 с. - С. 22.

2. Куприянов Б.В. Очерки общественной педагогики: авторские магеря Костромской области. - Кострома: Изд-во КГУ им. Н.А. Некрасова, 2001. -65 с.

3. Аетний отдых детей: концептуальные и нормативноправовые основы/ Сост. Панов А.В. - М.: НИИ семьи, 1998. $144 \mathrm{c}$.

4. Макаренко А.С. Книга дмя родитемей/ А.С. Макаренко. Петрозаводск: Ауч, 1959. - 186 с. - С. 11.

5. Морозов М.А. Маркетинговое исследование российского рынка детского туризма - Режим доступа: http://referent.mubint.ru/security/8/2731/1

6. Мудрик А.В. Социализация человека/ А.В. Мудрик. - М.: Изд. центр "Академия", 2004. - 321 с. - С. 24.

7. Панченко С.И. Педагогические основы профессиональной подготовки отрядных вожатых пионерских магерей груглогодичного типа: дисс канд пед. Наук. - М.: ВКШ при ЦК ВАКСМ, 1989. - C. 58.

8. Таран Ю.Н. Каникулы: социально-педагогические ориентиры. Н.Новгород: изд-во ООО "Педагогические техномогии", 2006. - C. 15

9. Юзефавичус Т.А. Советы бывалого вожатого. КИПАРИС 9. Учебно-практическое пособие дмя организаторов метнего отдыха детей. - М.: Педагогическое общество России, 2005. - 192 с. 


\title{
THEORETICAL AND METHODOLOGICAL BASES OF FORMATION OF THE LEGAL COMPETENCE OF THE STUDENTS OF MEDICAL INSTITUTE
}

\author{
Maria Soboleva ${ }^{1}$ \\ 1. Associate Professor of international and international private law, \\ Orel State University, Russia.
}

\begin{abstract}
The article gives a detailed description of the legal competence of health professionals; the conception and structure of the phenomenon is defined. The attention is paid to the content of the legal components of a healthcare specialist; the criteria and indicators of levels of its formedness are revealed.
\end{abstract}

Keywords: law, legal competence, legal competency.

В современных социально-экономических и нормативноправовых условиях функционирования системы здравоохранения существенно возрастают требования, предъявляемые к уровню правовой подготовки врачей.

Отношения мюдей в сфере медицины являются особо значимыми с правовой точки зрения, поскольку непосредственными объектами медицинского вмешательства являются такие конституционно закрепленные блага, как жизнь, здоровье, мичная физическая и психическая неприкосновенность. Права граждан в сфере охраны здоровья получили свое закрепление в ряде законов ("О санитарно-эпидемиологическом благополучии населения" от 30 марта 1999 года, "Об обязательном медицинском страховании в Российской Федерации" от 29 ноября 2010 года, "Об основах охраны здоровья граждан в Российской Федерации" от 21 ноября 2011 года), а также других медико-социальных нормативных правовых актах, число которых постоянно растет. Таким образом, одним из гмавных направцений развития здравоохранения в Российской Федерации становится правовое обеспечение врачебной деятельности. В связи с этим к выпускнику современного медицинского вуза предъявцяются более высокие требования в 
контексте обеспечения его профессиональной компетенции. Важнейшей ее составцяющей становится правовая компетенция, позволяющая юридически грамотно решать профессиональные задачи, относящиеся ко всем сферам деятельности выпускника.

Анализ материалов периодической печати, судебной практики показал, что незнание медицинскими работниками своих прав и обязанностей, оснований юридической ответственности создает реальные предпосылки дия совершения деяний, которые квалифицируются как должностные преступления, влекущие за собой юридическую ответственность. В то же время к числу обязательных требований к должности врача-специалиста относится знание Конституции Российской Федерации; законов и иных нормативно-правовых актов Российской Федерации в сфере здравоохранения, защиты прав потребителей и санитарноэпидемиологического бцагополучия населения [1]. Все это актуамизирует проблему формирования правовой компетенции студентов медицинского вуза как неотъемлемой части общего процесса становления профессиональной компетенции врача.

Анализ фундаментальных положений педагогической, психологической и юридической наук показал, что для решения научных и практических задач, связанных с формированием правовой компетенции, в науке накоплен определенный базис.

В частности, вопросы, связанные со структурой, содержанием профессиональной компетенции и условиями ее формирования и развития в процессе профессиональной подготовки специалистов, освещаются в работах отечественных исследователей: А.А. Андреева, В.И. Байденко, В.А. Болотова, Т.Г. Браже, А.А. Вербицкого, Э.Ф. Зеера, И.А. Зимней, О.М. Карпенко, А.М. Митяевой, В.В. Серикова, Ю.Г. Татура, А.В. Хуторского, В.Д. Шадрикова, а также в трудах зарубежных ученых: Ф. Вайнерта, Ж. Делора, Б. Оскарссона, Дж. Равенна, В. Хутмахера и др.

Отдельные вопросы профессионально-правовой компетенции специалистов рассматриваются в исследованиях И.В. Безукладниковой, Е.А. Болотовой, Ю.Ю. Ветютнева, Е.М. Кропанёвой, Е.А. Певцовой, Р.К. Русинова, А.А. Черемисиной.

Некоторые аспекты формирования правовой компетенции студентов в высших профессиональных образовательных учреждениях неюридического профиля освещаются в работах А.С. 
Аникиной, С.С. Воеводиной, Т.С. Волох, М.В. Горбушиной, С.В. Гурина, А.В. Коротун, А.В. Молчановой, О.А. Панова, М.Е. Поляковой, В.В. Потомахина и др.

При неоспоримой теоретической и практической значимости исследований указанных авторов следует отметить, что выдеменный нами аспект изучения формирования правовой компетенции студентов медицинского института остается неразработанным.

Анализ научной митературы по основам компетентностного подхода (И.Г. Агапов, В.И. Байденко, Ю.В. Варданян, А.К. Гейхман, И.В. Гришина, В. Гутмахер, В.А. Дегтерев, Э.Ф. Зеер, И.А. Зимняя, В.В. Краевский, Н.В. Кузьмина, А.К. Маркова, А.М. Митяева, Д. Мертенс, Б. Оскарсон, А.А. Петровская, Дж. Равен, В. В. Сериков, М.Н. Скаткин, В.А. Сластенин, Ю.Г. Татур, Р. Уайт, А.В. Хуторской, С.Е. Шишов, Г.В. Щедровицкий и др.); вопросам профессионально-правовой подготовки студентов вузов (А.С. Аникина, С.С. Воеводина, М.В. Горбушина, А.В. Коротун и др.) позволиц нам определить правовую компетениию студентов медииинского института как интегральное качество цичности, отражающее ее способность и готовность использовать правовые знания и умения, задаваемые образовательным стандартом, дия решения практических задач, реализуя при этом такие профессионально-значимые мичностные качества, как ответственность, коммуникативность, эмпатия, толерантность.

Среди профессиональных компетенций студентов медицинского института правовая компетенция занимает особое место, о чем свидетельствуют нормативные документы. Так, в Федеральном государственном образовательном стандарте высшего профессионального образования по специальности "Иечебное демо", закреплены требования к результатам правовой подготовки специалиста: знание норм зарубежного и информационного права, основных принципов и положений конституционного, гражданского, трудового, семейного, административного и уголовного права; знание прав пациента и врача, этических основ современного медицинского законодательства; умение ориентироваться в действующих нормативно-правовых актах о труде, применять нормы трудового законодательства в конкретных практических ситуациях, защищать гражданские права врачей и пациентов размичного возраста [2]. 
Изможенные требования $\mathrm{k}$ уровню правовой подготовки специалиста позволяют выделить следующие компоненты в структуре правовой компетенции: мотивационный, когнитивный и деятельностный. Мотиваиионный компонент включает систему профессионально-значимых мичностных качеств студентов, уровень оценки и отношения к праву, наличие положительного или отрицательного отношения к воспринимаемым знаниям, в результате которого на основе интереса формируется убеждение в мичной ценности правовых норм, уважение к праву, вырабатываются навыки правомерного поведения. Когнитивный компонент является теоретической основой правовой компетенции и отражает усвоение системы правовых знаний. Деятельностный компонент характеризует способность и готовность применять полученные правовые знания на практике, осуществлять социально-активное правомерное поведение в различных сферах деятельности, отстаивать свои права в случае их нарушения, владение правовой терминологией.

Формирование правовой компетенции студентов медицинского института мы рассматриваем как сложную динамичную систему, включающую следующие основные компоненты: цель, содержание, организационные формы, методы, результат, и описываем в виде структурно-содержательной модели (рис. 1).

Структурно-содержательная модель формирования правовой компетенции студентов медицинского института представмена совокупностью пяти взаимосвязанных блоков: целевого, содержательного, организационно-деятельностного, критериальнооценочного, результативного.

Целевой блок представмен единством цели, которая вытекает из социального заказа общества на подготовку специалистов, обладающих правовой компетенцией, и задач, обеспечивающих ее достижение.

Содержательный блок, предполагающий развитие мотивационного, когнитивного и деятельностного компонентов правовой компетенции, представлен дисциплиной "Правоведение", спецкурсом "Юридические основы деятельности врача" и используемым дидактическим материалом. 


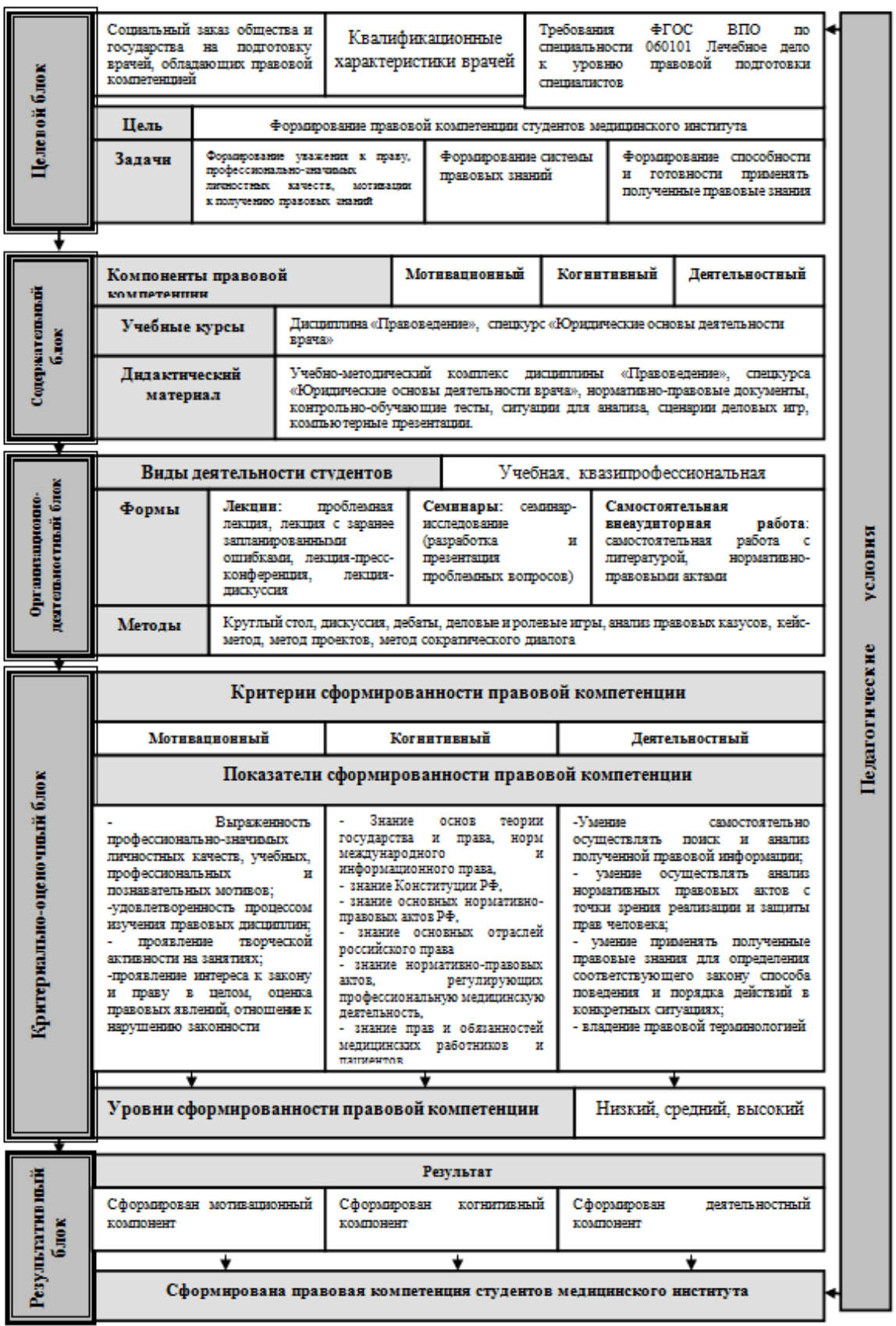

Рис. 1. Структурно-содержательная модемь формирования правовой компетенции студентов медицинского института 
Организационно-деятельностный блок включает организационную деятельность по формированию правовой компетенции студентов медицинского института в рамках учебной и квазипрофессиональной деятельности. В этом блоке раскрываются интерактивные формы и методы обучения, направценные на формирование правовой компетенции студентов-медиков.

Критериально-оценочный блок позволяет произвести качественную оценку формирования правовой компетенции. Он содержит критерии, показатели и уровни сформированности всех компонентов правовой компетенции. Данный блок оказывает организующее и контролирующее влияние на все этапы формирования правовой компетенции студентов.

Результативный блок характеризует достигнутый результат формирования правовой компетенции студентов медицинского института: сформированность правовой компетенции студентов.

Эффективность формирования правовой компетенции студентов медицинского института зависит от тех условий, в которых протекает учебный процесс. Мы выявили следующие педагогические условия формирования правовой компетениии студентов медииинского института:

- обеспечение мотивационного отношения студентов к праву как необходимому регулятору их будущей профессиональной деятельности;

- усиление профессионально-правовой направленности дисциплины "Правоведение»;

- разработка и внедрение в учебный процесс спецкурса "Юридические основы деятельности врача";

- использование комплекса интерактивных форм и методов обучения.

Оценка эффективности формирования правовой компетенции студентов медицинского института возможна с помощью соответствующего критериально - оценочного аппарата.

Исходя из анализа содержания компонентов правовой компетенции студентов медицинского института мы определили мотивационный, когнитивный и деятельностный критерии сформированности правовой компетенции, обосновали их показатели, которые служили ориентирами для проведения опытноэкспериментальной работы. 
Мотиваиионный критерий отражает эмоциональночувственные проявцения мичности по отношению к правовым нормам, фактам, явцениям, позволяет выявцять мотивацию к помучению правовых знаний и правомерного поведения. Данный критерий представлен совокупностью показателей: выраженность профессионально-значимых мичностных качеств, учебных, профессиональных и познавательных мотивов; проявление творческой активности на занятиях; удовцетворенность процессом изучения правовых дисциплин; проявление интереса к закону и праву в целом, оценка правовых явлений, отношение к нарушению законности.

Когнитивный критерий характеризует усвоение важнейших правовых знаний. Показателями когнитивного критерия явцяются: знание основ теории государства и права, норм международного и информационного права, знание Конституции РФ, знание основных отраслей российского права, знание основных нормативно-правовых актов РФ, знание нормативно-правовых актов, регулирующих профессиональную медицинскую деятельность, знание прав и обязанностей медицинских работников и пациентов.

Деятельностный критерий отражает умение применять полученные правовые знания на практике, осуществлять социально-активное правомерное поведение, владение правовой терминологией. Показателями деятельностного критерия явцяются умение самостоятельно осуществлять поиск, анализ и применение полученной правовой информации; осуществлять анализ нормативных правовых актов с точки зрения реализации и защиты прав человека; применять полученные правовые знания дия опредемения соответствующего закону способа поведения и порядка действий в конкретных ситуациях, вмадение правовой терминомогией.

Результаты опытно-экспериментальной работы показали, что формирование правовой компетенции студентов медицинского института на основе разработанной структурносодержательной модеми при обязательном соблюдении комплекса выявленных педагогических условий является эффективным. 


\section{References:}

1.Единый квалификационный справочник должностей руководителей, специалистов и служащих, утв. Приказом Министерства здравоохранения и социального развития Российской Федерации от 23 июля 2010 г. N 541н // Российская газета. - № 5296 от 27 сентября 2010 г.

2. Федеральный государственный образовательный стандарт высшего профессионального образования по специальности 060101 Аечебное демо. Режим доступа: http://ivo.garant.ru/SESSION/PILOT/main.htm. 


\title{
THE STUDY OF SPEECH DISORDERS IN YOUNG CHILDREN IN FOSTER FAMILIES
}

\author{
Lada Aleksandrova ${ }^{1} \&$ Svetlana Vatoropina $^{2}$
}

1. Candidate of Pedagogical Sciences, Associate Professor, Novgorod State University, Russia.

2. Candidate of Pedagogical Sciences, Novgorod State University, Russia.

\section{Abstract}

The article is devoted to study the nature of the delay in speech development of children from foster families and development of the system of correctional and pedagogical support.

Keywords: delay in speech development, foster family, correctional and pedagogical support, risk factors.

Под общим названием "замещающая семья" объединяются семьи, обладающие разными воспитательными потенциалами: семья усыновителей, опекунская, приемная и патронатная семьи. Феномен замещающей семьи находится в фокусе исследовательского интереса ряда наук: юриспруденции (С.А. Абрамова, Е.А. Борисова и др.), медицины (И.А. Ибрагимов, Р.В. Йорик и др.), социологии (Э.Р. Алексеева, И.И. Осипова и др.), психологии (А.А. Асламазова, И.И. Осипова, В.И. Ослон, Е.В. Ушакова и др.), педагогики (Ж.А. Захарова, Н.А. Палиева и др.). В отдельных специально-педагогических работах отражены поиски эффективных путей содействия замещающим семьям, воспитывающим детей с ограниченными возможностями здоровья. Однако до сих не предпринимались исследования, касающиеся специфики помощи замещающим семьям, принявшим на воспитание детей с нарушениями речи.

Между тем, известно, что воспитание в условиях особой социальной ситуации развития, получившей название "материнской депривации", создает высокие риски возникновения у ребенка речевой патологии (Е.В. Бордовская, М.И. Аисина, 
Р.Ш. Мухамедрахимов, Ю.А. Разенкова, Р. Шпитц и др.). Причем очевидно, что в депривационных условиях дети могут находиться как до попадания в замещающую семью, так и в период проживания в ней $[2,3,4,7,8]$. В то же время в программы подготовки замещающих родителей, разработанные в соответствии с приказом Министерства образования и Науки Российской Федерации от 23 мая 2011 года, не включены разделы, связанные с подготовкой родителей к речевому развитию детей раннего возраста, хотя именно этот возраст указывается как наиболее желательный в большинстве анкет потенциальных родителей. Вследствие этого нарушения речи у приемного ребенка часто оказываются незамеченными замещающими родителями, а будучи очевидными, списываются ими на возраст («еще маленький, потом говорить научится"). Тем самым упускаются сензитивные периоды, когда педагогическое вмешательство могмо бы быть наиболее эффективным.

В возрасте до трех цет все нарушения речи у детей принято обозначать термином "задержка речевого развития" (далее ЗРР). Она понимается как приостановка развития речевой функции ребенка вследствие нарушения биологических или/и социальных факторов. Известно, что среди детей с ЗРР есть как дети с органическими речевыми расстройствами, так и дети с временными, обратимыми нарушениями хода речевого онтогенеза $[1,5]$.

В ходе экспериментального исследования были реализованы задачи по выявлению природы ЗРР у детей из замещающих семей и разработке системы коррекционно-педагогического сопровождения. В данной статье остановимся на реализации первой задачи. В исследовании, проведенном в период с 2000 по 2014 годы, приняли участие 124 ребенка раннего возраста. Из них усыновленных - 12 (тайна усыновления не сохранялась по инициативе усыновителей), из приемных семей - 59, из опекунских семей - 53.

ДАя изучения состояния речевого развития был разработан диагностический комплекс, состоящий из двух модумей. Первый высокоформализованный, выстраивался с ориентацией на среднестатистические закономерности развития детей до трех мет. Отмечались трудности его применения в тех случаях, когда быма неизвестна точная дата рождения ребенка (8 случаев). Второй состоял из низкоформализованных методик: включенного наблю- 
дения; динамического наблюдения в структурно-дидактических (диагностическое занятие, организованная игра) и естественных условиях (кормление, прогулка и др.); анализа дневниковых записей, аудио-и видеоматериалов.

Оказалось, что речевое развитие 43 детей соответствует среднестатистическим возрастным нормативам. В дальнейшем ходе исследования эти не участия не принимали. Состояние речи детей в 81 случае укладывалось в картину задержки речевого развития. Для изучения причин ЗРР применялись обсервационные (педагогическое наблюдение - прямое, косвенное) и праксиметрические (анализ медицинской и педагогической документации и статистических материалов) методы.

Были изучены биологические и социальные факторы риска. Биологические были подемены на пренатальные, натальные и постнатальные. Нас интересовали сведения, касающиеся характера первого крика новорожденного, физиологической функции дыхания, наличия/отсутствия интенсивной терапии в неонатальном периоде. Отмечались причины раннего искусственного вскарммивания (стафилококк в материнском молоке, заболевания матери или ребенка, слабость сосательного рефлекса, временная размука с матерью, отказ от ребенка и др.).

Среди социальных нас интересовали: время проживания в неблагополучной кровной семье, госпитализации, воспитание в доме ребенка, неудачный опыт усыновцения и др., "стаж" проживания в замещающей семье.

Бымо выявлено, что анамнестические сведения 14 детей утрачены или фрагментарны. У остальных были выявлены: токсикозы беременности у матери (19), хронический алкоголизм матери (17), угроза прерывания беременности (14), заболевания матери во время беременности (15), акушерская патология (12), эмоциональная нагрузка (8), резус-конфцикт и групповая несовместимость крови (6), стимулирование родовой деятельности (9), роды в домашних условиях (2), Кесарево сечение (14), стремительные роды (8), обвитие пуповиной (7), асфиксия (19), невысокая (6/7 баммов) оценка по шкале Апгар (25), недоношенность (9). Отмечались также: диительная госпитализация (16), перевод из одного дома ребенка в другой (12), отсутствие материнской заботы в кровной семье (31), возврат из предыдущей замещающей семьи в учреждение (6). 
Мультифакторный анализ возможных причин возникновения ЗРР и проявлений ЗРР позволим выделить у обследованных детей четыре типа ЗРР.

ЗРР первого типа быма выявлена у 32 детей, не имеющих серьезных анамнестических рисков. Она была чаще свойственна детям, недавно помещенным в замещающие семьи, длительное время воспитывающимся в государственном учреждении и испытывающим влияние дополнительных депривационных факторов (госпитализация, смена персонала, перевод из одного учреждения в другое, возврат в государственное учреждение и др.). Она проявлямась не только в запаздывании становцения речевой функции по времени, но и в количественном аспекте проявления речевых нарушений. Во все исследованные периоды речевой продукции у детей было недостаточно. В первом полугодии жизни редко наблюдалось вслушивание и "замирание" в ответ на речевые звуки. Дети не отвечали на улыбку, обращение, не явцялись инициаторами взаимодействия. Звуковой состав "гуканья" и "гумения" мало отличался между собой, отсутствовала напевность звуков. Характерной чертой мепета было сужение его фонетического диапазона. Наблюдалась значительная (более 12 месяцев) задержка появцения слов, причем дети не стремились использовать вместо них мимические и кинетические знаки. Отмечалось снижение стремления к речевому подражанию. К верхней границе раннего возраста дети все еще использовали голофразы. Переход к употреблению двусловной фразы мишь начинался.

ГАавным отличием ЗРР второго типа явимось отставание появления речевых новообразований по времени. Данный тип ЗРР (12 человек) преобладал у детей, до помещения в замещающую семью воспитывающихся в учреждениях, но не испытывающих влияния дополнительных депривационных факторов. У детей отмечалось преобладание более ранних видов речевой продукции на всех возрастных этапах. Так к концу первого полугодия жизни пцач и крик все еще преобладали над гулением. Аепет появлялся мишь после 8-9 месяцев. САова появлялись с задержкой в диапазоне от 6 до 12 месяцев. Подавцяющее большинство слов относились к категории номинаций. Дети стремились к речевому подражанию, однако отмечались затруднения в освоении речевых антиципаций. До 2,5 мет сохранялось преобладание жестов над вербальными формами общения. Период "мексического взры- 


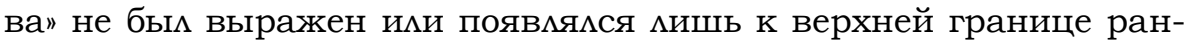
него возраста. Дети редко использовали семантические категории принадмежности, местопоможения, желания, требования, покидания, отрицания, отказа. Из всех морфологических категорий к трем годам дети усваивали мишь категорию числа. Категории падежа, склонения существительных, вида, наклонения, времени глагола мишь начинали усваиваться. Отмечалось "застревание" на этапе двусловных предложений. Трехсложными предложениями

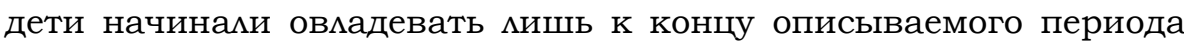
развития.

Третий muп ЗРР наблюдался у 26 детей и характеризовался подчеркнутой неравномерностью речевого развития. Он встречался чаще у детей с изменяющимся депривационным сценарием (они некоторое время находились в неблагополучных кровных семьях, затем были переведены в учреждение, помещены в замещающую семью и др.). Воспользовавшись известным термином "лексический взрыв", мы условно употребили как образные понятия "фонетический и грамматический взрывы". Они выражались в том, что после диитемьных периодов "речевого затишья", за короткое время у детей бурно появлялись речевые новообразования. Причем наблюдались не только случаи, когда они в речи детей упрочивались, но и такие, когда, появившись, "речевые достижения" как будто утрачивались (например, ребенок переставал использовать двух-трехсловную фразу и на диительный период возвращался к голофразе). Причем периоды речевых "скачков" и "утрат" не всегда совпадали с изменениями "депривационного сценария". Те и другие могми наблюдаться отсрочено, когда, казамось, что ребенок уже адаптировался к новым условиям.

ЗРР четвертого типа отмечалась у 11 детей, имеющих парциальные и комплексные расстройства или анамалии строения речевого аппарата. У них были выявлены прогностические признаки: дизартрии (6), открытой ринолалии (1), моторной алалии (2), механической дислалии (2).

Таким образом, стало очевидным, что: 1) в большинстве случаев ЗРР имеет мультифакторную природу, то есть обусловливается сочетанием биологических и социальных факторов; 2) дети из замещающих семей с ЗРР представцяют собою неоднородную группу; 3) все дети нуждаются в коррекционнопедагогическом сопровождении; 4) необходима специальная под- 
готовка замещающих родителей к речевому развитию приемных детей.

\section{References:}

1. Датешидзе Т. А.Система коррекционной работы с детьми раннего возраста с задержкой речевого развития. СПб.: Речь. 2004. 145 c.

2. Зайцев Д.В. Социологический анализ современной семьи в России // Дефектология. 2001. № 6. С. 3 - 10.

3. Захарова Ж.А. Замещающая семья как альтернатива государственной системе жизнеустройства детей-сирот / Ж.А.Захарова / Вестник Костромского государственного университета им. Н.А.Некрасова. 2006. Т.12. № 1. С. 71-75.

4. Дементьева, И.Ф, Олиференко, И.Я. Приемная семья институт защиты детства. М. 2000. С. 44-47.

5. Дмитриева Е.Е. Коммуникативное развитие детей с $е г-$ кими формами психического недоразвития на ранних этапах онтогенеза: монография. Нижегородский государственный педагогический университет. Н.Новгород: НГПУ. 2004. 258c.

6. Корнев А.Н. Основы могопатологии детского возраста: клинические и психомогические аспекты. СПб.: Речь: 2006. 380 с.

7. Осипова И.И. Замещающая семья в России // Психологическая наука и образование. 2006. № 2. С.70-81. Библиогр.: с.81.

8. Палиева Н.А Концепция комплексного сопровождения развития детей-сирот и детей, оставшихся без попечения родитемей. Ставрополь. 2008. 41с. 


\title{
SYSTEM AND ACTIVITY APPROACH IN TRAINING OF IT SPECIALISTS AS THE BASIS OF REALIZATION OF FGOS
}

\author{
Yekaterina Gorneva ${ }^{1} \&$ Dina Pogonysheva ${ }^{2}$
}

1. Associate professor, candidate of pedagogical sciences, Bryansk State University named after Academician I.G. Petrovsky, Russia.

2. Professor, doctor of pedagogical sciences, Bryansk State University named after Academician I.G. Petrovsky, Russia.

\section{Abstract}

In article the essence is considered and the principles of system and activity approach are systematized, ways of its realization are proved when training bachelors in the directions 080700.62 "Business informatics", 230700.62 "Applied informatics", 230400.62 "Information systems and technologies".

Keywords: System and activity approach, higher education, federal state educational standard, IT specialist, competence.

В условиях перехода к двухуровневой модели образования (бакалавр - магистр) перед преподавателями российской высшей школы ставятся задачи формирования у выпускников вузов не только предметных знаний, но и универсальных учебных действий, обеспечивающих все дисциплины ООП, а также набора компетенций, позволяющих специалистам действовать в новой обстановке на качественно высоком уровне. Реализации данных задач в полной мере способствует системно-деятельностный подход, смещающий акценты в образовании на активную деятельность студентов, в процессе которой "они развиваются как мичность" [1; 8]. Так, новые образовательные стандарты ВПО в качестве одного из показателей успешности освоения студентом основной образовательной программы определяют его способность к решению профессионально ориентированных учебнопрактических задач на основании:

- системы научных знаний о предметной области; 
- умений учебно-познавательной, научно-исследовательской, проектной деятельности;

- обобщённых способов деятельности, коммуникативных (навыки эффективного сотрудничества) и информационных (навыки работы с информацией и информационнокоммуникационными технологиями) компетенций;

- навыков самоорганизации (умение ставить цели и организовать её достижение, способность полноценно использовать мичностные ресурсы, проводить самоанализ и самооценку);

- навыков самообразовательной деятельности (готовность конструировать и осуществлять собственную образовательную траекторию на протяжении всей жизни);

- навыков креативной (творческой) деятельности, основными показателями которой могут служить чуткость к противоречиям; прогностичность, критичность мышления, наличие своего мнения и пр.;

- индивидуально-психологических и ценностно-смысловых (мировоззренческих) характеристик мичности [2; 3; 4; 9 и др.].

Основные идеи системно-деятельностного подхода раскрывают следующие утверждения:

- деятельность - это система, нацеленная на результат (развитие, саморазвитие, самовоспитание личности);

- достижение результата возможно мишь при условии наличия обратной связи со студентами и обеспечении максимальной самостоятельности их познавательной деятельности;

- образовательный процесс должен быть организован таким образом, чтобы обучаемые выступали субъектами учебной деятельности, осознающими важность получения знаний, способными учить себя (учить+ся), нести мичную ответственность за результаты обучения, анализировать свою деятельность, оценивать успехи, опредемять причины ошибок и неудач, вмадеть умениями построения собственной образовательной траектории. Дия этого должен быть осуществлен переход от информационного репродуктивного знания к знанию действия [3; $8 ; 10$ и др.].

Преимущества системно-деятельностного подхода в организации учебного процесса им^юстрирует таблица 1. 
Таблица 1

Сравнительная характеристика объяснительно-имлюстративного и системно-деятельностного методов обучения

\begin{tabular}{|c|c|c|}
\hline $\begin{array}{l}\text { Объяснительно- } \\
\text { имлюстративный }\end{array}$ & $\begin{array}{c}\text { Компоненты учебной } \\
\text { деятельности }\end{array}$ & Системно-деятельностный \\
\hline $\begin{array}{l}\text { Задается } \text { препода- } \\
\text { вателем }\end{array}$ & $\begin{array}{l}\text { Цель - предполагае- } \\
\text { мый результат }\end{array}$ & $\begin{array}{l}\text { Внутреннее принятие цели } \\
\text { достигается путем пробце- } \\
\text { матизации }\end{array}$ \\
\hline \begin{tabular}{|l|} 
Используются \\
внешние мотивы
\end{tabular} & $\begin{array}{l}\text { Мотивы - побудители } \\
\text { к деятельности } \\
\end{array}$ & $\begin{array}{l}\text { Опора на внутренние моти- } \\
\text { вы }\end{array}$ \\
\hline \multirow[t]{2}{*}{$\begin{array}{l}\text { Инвариантные, вы- } \\
\text { бираются препода- } \\
\text { вателем }\end{array}$} & $\begin{array}{l}\text { Средства - способы } \\
\text { осуществцения дея- } \\
\text { темьности }\end{array}$ & \multirow{2}{*}{$\begin{array}{l}\text { Вариативные, выбираются } \\
\text { студентами самостоятемьно } \\
\text { или совместно с преподава- } \\
\text { телем }\end{array}$} \\
\hline & \begin{tabular}{|l} 
Действия - основной \\
элемент деятельности \\
\end{tabular} & \\
\hline $\begin{array}{l}\text { Уровень } \\
\text { знаний } \\
\end{array}$ & $\begin{array}{l}\text { Результат - конечный } \\
\text { продукт }\end{array}$ & $\begin{array}{l}\text { Прогресс в Аичностном раз- } \\
\text { витии }\end{array}$ \\
\hline $\begin{array}{l}\text { Сравнение резуль- } \\
\text { тативности с этало- } \\
\text { нами }\end{array}$ & $\begin{array}{l}\text { Оценка - критерий } \\
\text { достижения цели }\end{array}$ & $\begin{array}{l}\text { Самооценка на основе при- } \\
\text { менения индивидуальных } \\
\text { эталонов достижений }\end{array}$ \\
\hline
\end{tabular}

Реализация технологии системно-деятельностного подхода в практическом преподавании обеспечивается следующими дидактическими принципами:

1) Принцип деятельности - заключается в том, что обучаемый, получая знания не в готовом виде, а добывая их сам, осознает при этом содержание и формы своей учебной деятельности, понимает и принимает систему ее норм, активно участвует в их совершенствовании, что способствует активному успешному формированию его профессиональных компетенций.

2) Принцип непрерывности - означает преемственность между всеми ступенями и этапами обучения в вузе на уровне технологии, содержания и методик реализации образовательного процесса.

3) Принцип целостности - предполагает формирование у студентов обобщенного системного представцения о мире (природе, обществе, самом себе, социокультурном мире и мире деятельности, о роли и месте каждой науки в системе наук).

4) Принцип минимакса - означает, с одной стороны, необходимость создания в высшей школе условий для освоения студентами содержания образования на максимальном для них 
уровне. С другой стороны, должно быть обеспечено усвоение содержания образования на уровне не ниже социально безопасного минимума (государственного стандарта знаний).

5) Принцип психологической комфортности - предполагает снятие всех стрессообразующих факторов учебного процесса, создание на учебных занятиях доброжелательной атмосферы, ориентированной на реализацию идей педагогики сотрудничества, развитие диалоговых форм общения.

6) Принцип вариативности - предполагает формирование у обучаемых способностей к систематическому перебору вариантов и адекватному принятию решений в ситуациях выбора.

7) Принцип творчества - означает максимальную ориентацию на творческое начало в образовательном процессе, приобретение студентами собственного опыта творческой деятельности [5].

Системно-деятельностный подход нашел свое воплощение в третьем поколении Федеральных государственных образовательных стандартов по направлениям подготовки 080700.62 «Бизнесинформатика", 230700.62 "Прикладная информатика", 230400.62 "Информационные системы и технологии". Так, освоение основной образовательной программы бакалавриата IT-профиля направлено на достижение целей, представленных в таблице 2.

Таблица 2

Цели освоения ООП бакалаврами IT-направлений

\begin{tabular}{|c|c|}
\hline $\begin{array}{c}\text { Направление и } \\
\text { профиць подготовки }\end{array}$ & Цели освоения ООП \\
\hline $\begin{array}{l}080700.62 \text { "Бизнес- } \\
\text { информатика", про- } \\
\text { фимь - "Эмектронный } \\
\text { бизнес" }\end{array}$ & $\begin{array}{l}\text { - овмадение средствами стратегического плани- } \\
\text { рования развития ИС и ИКТ управмения пред- } \\
\text { приятием, освоение основных методик органи- } \\
\text { зации процессов их жизненного цикла; } \\
\text { - формирование навыков проектирования архи- } \\
\text { тектуры эмектронных предприятий; } \\
\text { - воспитание познавательной активности и ин- } \\
\text { тереса к сфере IT }\end{array}$ \\
\hline $\begin{array}{l}230700.62 \text { "Приклад- } \\
\text { ная информатика", } \\
\text { профиль "Приклад- } \\
\text { ная информатика в } \\
\text { экономике" }\end{array}$ & $\begin{array}{l}\text { - формирование навыков системного анализа } \\
\text { прикладной области; } \\
\text { - освоение методов и средств разработки, раз- } \\
\text { вития, сопровождения и эксплуатации ИС и ее } \\
\text { компонентов; } \\
\text { - развитие навыков управцения проектами ин- } \\
\text { форматизации предприятий и организаций }\end{array}$ \\
\hline
\end{tabular}


Окончание таблицы 2

\begin{tabular}{|c|c|}
\hline $\begin{array}{c}\text { Направление и } \\
\text { профриць подготовки }\end{array}$ & Цели освоения ООП \\
\hline $\begin{array}{l}230400.62 \text { "Информа- } \\
\text { ционные системы и } \\
\text { технологии", профиль } \\
\text { - "Информационные } \\
\text { системы и техномогии } \\
\text { в банковском деме" }\end{array}$ & $\begin{array}{l}\text { - овладение методологией проектирования ин- } \\
\text { формационных систем, развитие готовности и } \\
\text { способности с их помощью управлять качеством } \\
\text { технологических процессов в предметной облас- } \\
\text { ти; } \\
\text { - формирование навыков проектирования базо- } \\
\text { вых и прикладных информационных технологий, } \\
\text { разработки средств их реализации и автомати- } \\
\text { зированного проектирования, сборки программ- } \\
\text { ной системы из готовых компонентов, инсталця- } \\
\text { ции, отладки и настройки, ввода в эксплуата- } \\
\text { цию, сопровождения и адаптации к изменяю- } \\
\text { щимся условиям функционирования }\end{array}$ \\
\hline
\end{tabular}

Таким образом, цели профессиональной подготовки ITспециалистов носят деятельностный характер и определяют обязательный минимум содержания основных образовательных программ, раскрытый в таблице 3.

Таблица 3

Минимум содержания ООП бакалавриата по IT-направмениям подготовки

\begin{tabular}{|c|c|}
\hline $\begin{array}{c}\text { Направление и } \\
\text { профимь подготовки }\end{array}$ & Основные содержательные блоки \\
\hline $\begin{array}{l}080700.62 \text { "Бизнес- } \\
\text { информатика", про- } \\
\text { фимь - "Электронный } \\
\text { бизнес" }\end{array}$ & $\begin{array}{l}\text { - архитектура электронного предприятия; } \\
\text { - стратегическое планирование развития ИС и } \\
\text { ИКТ управмения предприятием; } \\
\text { - организация процессов жизненного цикла ИС } \\
\text { и ИКТ управления предприятием; } \\
\text { - аналитическая поддержка процессов принятия } \\
\text { решений дмя управления предприятием; } \\
\text { - методы и средства создания и развития элек- } \\
\text { тронных бизнесов (сайтов, порталов, интернет- } \\
\text { магазинов); } \\
\text { - инновационные процессы в сфере ИКТ }\end{array}$ \\
\hline $\begin{array}{l}230700.62 \text { "Приклад- } \\
\text { ная информатика", } \\
\text { профиль - "Приклад- } \\
\text { ная информатика в } \\
\text { экономике" }\end{array}$ & $\begin{array}{l}\text { - данные, информация, знания; } \\
\text { - прикладные информационные процессы и сис- } \\
\text { темы; } \\
\text { - информатизация прикладных областей; } \\
\text { - методы и средства разработки и развития ИС } \\
\text { и ее компонентов; } \\
\text { - IТ-консалтинг }\end{array}$ \\
\hline
\end{tabular}


Окончание таблицы 2

\begin{tabular}{|l|l|}
\hline \multicolumn{1}{|c|}{$\begin{array}{l}\text { Направление и } \\
\text { профимь подготовки }\end{array}$} & \multicolumn{1}{|c|}{ Основные содержательные блоки } \\
\hline 230400.62 "Информа- & - информационные процессы, технологии, сис- \\
ционные системы и и & темы и сети, их инструментальное (программное, \\
технологии", профимь - & техническое, организационное) обеспечение; \\
"Информационные & - способы и методы проектирования, отладки, \\
системы и техномогии & производства и эксплуатации информационных \\
в банковском деме» & техномогий и систем (по областям) \\
\hline
\end{tabular}

В результате освоения ООП выпускники вузов должны знать:

- по направлению подготовки 080700.62 «Бизнесинформатика», профиль - "Эмектронный бизнес»:

- методики анализа, проектирования архитектуры электронных предприятий, основные инструменты их создания и развития;

- возможности ИС и ИКТ для управления бизнесом;

- методы и средства разработки ИС предприятия;

- основные тенденции развития сферы ИТ;

- по направлению подготовки 230700.62 «Прикладная информатика", профиль - "Прикладная информатика в экономике»:

- теоретические основы информации, данных, информационных процессов и систем;

- методики системного анализа и моделирования прикладной области, способы и средства разработки требований к созданию и развитию ИС и ее компонентов;

- принципы автоматизации и информатизации прикладных процессов и создания ИС в прикладных областях;

- сущность, принципы, основной инструментарий ITконсалтинга;

- по направлению подготовки 230400.62 «Информационные системы и технологии", профимь - «Информационные системы и технологии в банковском деме»:

- информационные системы и сети, их математическое, информационное и программное обеспечение;

- способы и методы проектирования, отмадки, производства и эксплуатации технических и программных средств банковских информационных систем. 
В результате изучения дисциплин базовой и вариативной части циклов бакалавры должны уметь:

- по направлению подготовки 080700.62 «Бизнесинформатика", профимь - «Электронный бизнес»:

- осуществцять поиск, сбор, обработку, анализ и систематизацию информации в экономике, управмении и ИКТ;

- анализировать адекватность, полноту и сбалансированность информационной модели и схемы информационных потоков предприятия;

- разрабатывать проекты совершенствования бизнеспроцессов и ИТ-инфраструктуры предприятия, выбирать наибомее эффективные ИС и ИКТ дмя управления бизнесом;

- управцять электронным предприятием и подраздемениями эмектронного бизнеса несетевых компаний;

- разрабатывать и внедрять корпоративные порталы и системы эмектронного документооборота;

- консультировать по способам эффективного продвижения сайтов;

- создавать малые предприятия в сфере ИТ-аутсорсинга;

- коммерциализировать инновационные разработки в обмасти эмектронного предпринимательства сферы малого и среднего бизнеса;

- по направлению подготовки 230700.62 «Прикладная информатика", профиль - «Прикладная информатика в экономике»:

- моделировать прикладные и информационные процессы;

- программировать, тестировать и документировать приложения;

- внедрять, адаптировать, настраивать и интегрировать проектные решения по созданию ИС;

- управлять информационными процессами, ресурсами, системами, сервисами разного уровня и масштаба на предприятиях, в регионах, в органах управления экономическим развитием, сетевых компаниях;

- по направлению подготовки 230400.62 «Информационные системы и технологии", профиль - "Информационные системы и технологии в банковском деме»:

- проектировать, разрабатывать и реализовывать банковские информационные системы; 
- разрабатывать информационные сайты компаний и организаций, создавать базы данных, в том числе и для распределенных информационных систем.

С учетом рекомендаций, изможенных в работах Н.С. Бусловой [2], О.Р. Петросян [6], С.Я. Рогозиной [7], С.И. Смирновой [8] и др., нами определены основные направления реализации системно-деятельностного подхода при подготовке бакалавров информационного профияя:

1. Проведение учебных мероприятий, предполагающих интеграцию содержания учебных дисциплин. Переход от внутрипредметных связей к межпредметным позволяет студентам переносить способы действий с одних объектов на другие, одновременно проследить весь процесс выполнения действий от цели до результата за счет увеличения доли обобщающих знаний, осмысменно воспринимать каждый этап работы, а также обеспечивает применение полученных знаний в реальных условиях.

2. Систематическое решение проблемных профессиональноориентированных задач. Студенты не получают "готовые" знания, а оказываются в ситуации поиска, что способствует развитию навыков доказательства собственных теорий, формулировки выводов, обоснованного отстаивания своей точки зрения. Способствуют решению проблемных заданий самостоятельная работа с митературой, Интернет-ресурсами, групповые формы работы (в парах и малых группах).

3. Применение активных и интерактивных методик обучения как специальных форм познавательной деятельности студентов вузов (интерактивная мекция, кейс-метод, компьютерные симуляции и пр.).

4. Организация исследовательской и проектно-творческой деятельности, при вовлечении в которую студенты сталкиваются с необходимостью самостоятельного получения знаний, применения их в нестандартных ситуациях, максимально приближенных к условиям реального профессионального труда.

5. Использование в процессе профессиональной подготовки дифференцированных (базового и повышенного уровня сложности) заданий в рамках аудиторного обучения, самостоятельной и индивидуальной работы. Дифференциация предметного содержания позволяет предупредить и преодолеть трудности в освоении студентами учебного материала, реализовывать индивиду- 
альную образовательную траекторию, организовать и своевременно проводить цеменаправленную коррекционную работу в зависимости от успешности обучения с каждым из студентов.

6. Моделирование и анализ ситуаций, возникающих в реальной профессиональной деятельности специалиста IT-профиля.

7. Систематическая педагогическая диагностика, позвомяющая анализировать результативность деятельности обучаемых и динамику развития их компетенций и профессионально важных качеств Аичности.

8. Подобный подход был реализован в практике подготовки бакалавров IT-профиля в Брянском госуниверситете. Результаты исследований показали, что системно-деятельностный подход качественным образом изменяет организацию процесса познания путем смещения его в сторону системного мышления, позволяет оптимизировать формы самостоятельной работы студентов, индивидуализировать учебный процесс, использовать возможности каждой дисциплины для развития у студентов вузов универсальных учебных действий. Побудительными мотивами применения системно-деятельностного подхода при реализации ООП бакалавриата также могут служить: более высокая интенсивность работы, ее организованность, объективность оценки, дисциплинированность, предметная новизна.

\section{References:}

1. Аксенова Н.И. Системно-деятельностный подход как основа формирования метапредметных результатов // Теория и практика образования в современном мире: материалы междунар. заоч. науч. конф. (г. Санкт-Петербург, февраль 2012 г.). СПб.: Реноме, 2012. - С. 140-142.

2. Буслова Н.С. Системно-деятельностный подход как средство повышения качества обучения теоретическим основам информатики в условиях информационно-предметной среды педагогического вуза: Автореферат дисс ... кандидата пед. наук: 13.00.02. - Омск, 2006. - 21 с.

3. Каримова Э.Ю. Реализация системно-деятельностного подхода как основа определения требований к результатам образования в рамках ФГОС // Фестиваль педагогических идей «От- 
крытый урок". URL: http://festival.1september.ru/articles/595419/ (дата обращения: 04.01.2014).

4. Аыбашева $\Lambda . Н$. Методические рекомендации "Системно деятельностный подход в дополнительном образовании". - Карпогоры: МБОУ ДОД, 2011. URL: http://pinimc.org.ru/ index.php?option $=\quad$ com_content\&view $=$ article $\&$ id $=95:-q-\&$ catid $=14$ : 2011-09-08-11-54-59\&Itemid=17 (дата обращения: 27.12.2013).

5. Методические рекомендации по организации урока в рамках системно-деятельностного подхода [Эмектронный ресурс]. URL: http://omczo.org/publ/393-1-0-2468 (дата обращения: 09.01.2014).

6. Петросян О.Р. Реализация системно-деятельностного подхода в преподавании физики // Официальный сайт Социальной сети работников образования "Наша сеть». - Йошкар-Ола, 2013. URL: http://nsportal.ru/shkola/estestvoznanie/library/realizaciyasistemno-deyatelnostnogo-podhoda-v-prepodavanii-fiziki (дата обращения: 13.12.2013).

7. Рогозина С.Я. Реализация системно-деятельностного подхода в преподавании информатики // Официальный сайт Социальной сети работников образования "Наша сеть». - Йошкар-Ола, 2013. URL: http://nsportal.ru/shkola/informatika-iikt/library/realizaciya-sistemno-deyatelnostnogo-podhoda-vprepodavanii (дата обращения: 03.01.2014).

8. Смирнова С.И. Системно-деятельностный подход к организации образовательного процесса: понятие, дидактические принципы, технологии // Официальный сайт Социальной сети работников образования "Наша сеть». - Йошкар-Ола, 2013. URL: http://nsportal.ru/ shkola/raznoe/library/pedsovet-po-temesistemno-deyatelnostnyi-podkhod-k-organizatsii-obrazovatelnog (дата обращения: 06.12.2013).

9. Хуторской А.В. Системно-деятельностный подход в обучении: Научно-методическое пособие. - М.: Изд-во “Эйдос"; Издво Института образования человека, 2012. - 63 с.

10. Янушевский В.Н. Системно-деятельностный подход в образовании в контексте ФГОС второго поколения: цели, программы, технологии. - УАьяновск: ОГБОУ ДПО “УИПКПРО", 2013. URL: http://ipk.ulstu.ru/?q=node/2750 (дата обращения: 04.05.2013). 


\title{
APPLICATION OF INTERACTIVE METHODS OF TRAINING, AS A CONDITION OF INCREASE OF MOTIVATION OF STUDENTS TO DISCIPLINE STUDYING "PHILOSOPHY AND EDUCATION HISTORY"
}

\author{
Yekaterina Gorneva ${ }^{1} \&$ Dina Pogonysheva ${ }^{2}$
}

1. Associate professor, candidate of pedagogical sciences, Bryansk

State University named after Academician I.G. Petrovsky, Russia.

2. Professor, doctor of pedagogical sciences, Bryansk State University named after Academician I.G. Petrovsky, Russia.

\section{Abstract}

The article reveals the essence of interactive teaching methods in the preparation of future teachers. As well as the stages of work in the classroom on the philosophy and history of education. The role of interactive teaching methods as one of the conditions to increase the motivation to study subjects.

Keywords: interactive teaching methods, teachers, students, motivation.

Мотивация представцяет собой важный аспект Аичности, на котором замыкаются такие её качественные характеристики, как смысложизненные ценности, цели, направленность, воля. В роли мотивов могут выступать эмоции, идеалы, установки, потребности, вцечения, интересы. Без должной мотивации учебная деятельность превращается в формальный процесс, источник психических травм и комплексов.

Высокой мотивации студентов к образованию можно добиться, создавая в ходе обучения ситуацию успеха дия каждого обучающегося, сопряжённую с повышением интереса к изучению предмета и ростом их потребности к познанию. Таким требованиям отвечают современные интерактивные методы обучения, в основе которых межит совместная познавательная деятельность преподавателя и студента. 
Под интерактивными методами понимается система правиц взаимодействия преподавателя и студента в форме учебных игр и ситуаций, обеспечивающая педагогически эффективное познавательное общение.

Интерактивные методы обучения создают дидактические условия дмя переживания учащимися ситуации успеха в процессе учебной деятельности. Они реализуют творческий потенциал студентов, активизируют их познавательную активность.

Интерактивное обучение определяет способы продуктивного, критического осмысления информации. В первую очередь, оно даёт простор для использования различных модемей, знаковых систем, помогающих определённым образом структурировать большой поток информации, выделяя необходимое для активного пользования. Содержание учебного материала по истории включает множество различных видов знаний, что во многом опредемяет сложность и противоречивость его понимания и усвоения студентами на разных этапах обучения. Уже по этой причине это прекрасная основа для творческого использования интерактивных методов обучения, определяющих успех и развитие мотивации у студентов. Важно, что интерактивные формы занятий основаны на самостоятельной работе с размичными видами исторической информации, на разнообразных приёмах сбора, обработки и презентации результатов своей творческой поисковой деятельности, на вариативности способов коммуникации в учебных группах.

При использовании интерактивных методов обучения отношения между преподавателем и студентом должны основываться на принципах доверия, доброжелательности, партнерства, взаимопонимания, взаимовыручки и поддержки, терпимости, учета и уважения интересов, возможностей друг друга. Основой деятельности преподавателя в условиях интерактивного обучения явАяется Аичностно-ориентированный подход, который требует соблюдения гуманной педагогической позиции, ценностного отношения к обучающемуся, его творчеству, создания культурноинформационной и предметно-развивающей среды, владения методикой и основами образовательной технологии. В процессе организации, управления и контроля за развитием интерактивного общения между студентами преподаватель преимущественно использует косвенные приемы педагогической деятельности, 
предоставцяя обучающимся самостоятельность в выборе средств достижения цели, адекватных учебных действий, партнеров. Он лишь организует учебную деятельность, управляет ею, корректирует по необходимости и оценивает (часто с помощью самих обучающихся).

Наиболее эффективным способом организации занятий с применением интерактивных форм и методов обучения явцяется комлективный способ организации занятий, который в большей степени отвечает задачам интерактивной деятельности обучаемых.

Основным признаком групповых форм занятий явцяется общность учебной ситуации, когда все обучающиеся класса выполняют одно и то же задание за определенный промежуток времени, одним и тем же способом и одинаковыми средствами. Второй признак групповых занятий - одинаковый маршрут освоения учебной программы, подразумевающий единство последовательности изучения раздемов, тем учебного материала.

Вопросы и задания, которые предлагаются для изучения, обсуждения обучающимся, непременно должны быть проблемного, исследовательского, развивающего и творческого характера, разного уровня трудности и сложности. Репродуктивные вопросы в этом случае неэффективны.

Примерные этапы интерактивной работы: этап подготовки педагога и учащихся к интерактивному обучению; этап комплектования групп; этап учебной деятельности обучающихся в группе; этап презентации группового решения; этап экспертизы (на усмотрение преподавателя); этап рефмексии прошедшего занятия.

Мы используем интерактивные методы на занятиях по "Фимософии и истории образования" в виде:

1. Уроков с применением кейс-технологии. Преимущество данной технологии состоит в том, что обучающимся предоставцяется возможность погрузиться в конкретную ситуацию, осознать себя участником каких-либо исторических событий, встать на чью-либо позицию. Наиболее эффективно данная технология применяется на уроках, где необходимо рассмотреть конкретные события, взгляды, мнения (нпр. при изучение таких тем: «Педагогические идеи Ж.-Ж. Руссо", "Школа и педагогическая мысль в эпоху Возрождения" и др.). 
Путешествие в другое время. Представьте, что у вас есть возможность отправиться на машине времени в Аюбую страну средневековья. Составьте программу полета: Укажите век (год), в который вам хотелось бы перенестись.

Назовите страну, которую вы хотели бы посетить.

Выберите, в роли какого ученого-педагога вам хотелось бы находиться во время путешествия и т.д.

Обоснуйте ваш выбор века (года), страны и роли. Определите цель вашего путешествия. По окончании путешествия составьте план-отчет. В зависимости от цели путешествия включите в него описание внешнего вида мюдей, орудий труда, оружия, а также архитектурных памятников, произведений искусства; характеристику выдающихся исторических мичностей; беседы с ююдьми этой эпохи. Как правимо, студенты с интересом воспринимают подобные задания. Описание типичных эпизодов ими введение в рассказ диалогов не вызывают у них затруднений.

2. Уроков с применением технологии "Аквариум". Данная технология очень эффективна при изучении спорных вопросов истории педагогики, поскольку она позволяет создать ситуацию дебатов, когда обучающиеся не только занимают определенную позицию по спорному вопросу, но и отстаивают ее друг перед другом, убеждают в своей правоте.

3. Уроков с применением игровой технологии. В этом случае обучающиеся также могут поставить себя на место определенных ученых-педагогов, "прожить" какую-либо ситуацию.

Данная технология эффективна, когда необходимо воссоздать какую-либо деятельность, поступки конкретной историче-

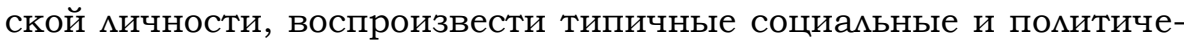
ские ситуации в концентрированном виде. В ходе игровой деятельности даже ученики в большинстве случаев не принимающие активного участия в ходе занятия, но желающие получить знания в готовом виде, с удовольствием включаются в процесс поиска информации и ответов.

4. Уроков с применением технологии развития критического мышления. Данная технология позволяет глубоко осмыслить информацию, "пропустить через себя", выработать опредеменное отношение к ней, поэтому ее уместно применят на занятиях при изучении трудов ученых-педагогов. 
5. Уроков с применением ИКТ. Поле деятельности с применением данной технологии обширно, поэтому ее можно применять буквально на всех занятиях. Это уроки с использованием мультимедиа презентаций (при изучении нового материала, защита проектов обучающихся), уроки компьютерной поддержкой (проектная деятельность студентов, проверка знаний).

Мотивацию обучающихся необходимо использовать, чтобы учебная деятельность не превратилась в формальный процесс. Находить способы мотивации нужно учитывая требования и возможности сегодняшнего дня. Пришло время, когда обучающемуся не только необходимо, но и интересно использовать интерактивные технологии в процессе образования, и это обстоятельство должен использовать педагог для достижения наиболее высоких результатов. В современном обществе, где одним из важных этапов социализации являются не только знания, а еще и умение их применять в практической деятельности, вуз должен учитывать все возможности и достоинства интерактивных методов обучения, а значит идти в ногу со временем.

В вузе начинают формироваться и развиваться такие ключевые компетентности, как информационная, коммуникативная, проблемная, кооперативная, а помогают в этом процессе интерактивные методы обучения. Это приводит к высоким образовательным результатам, удовлетворенности своей деятельностью, как преподавателя, так и студентов. И если студент мегко выполняет свою работу, проявцяет заинтересованность, удовлетворен ее результатами, то и мотивация к изучению такого предмета у него значительно вырастает. Поэтому одним из передовых способов повышения мотивации к изучению "Фимософии и истории образования" является применение интерактивных методов обучения.

Рассмотренные в настоящей статье интерактивные методы обучения и образовательные технологии направлены, прежде всего, на повышение собственной активности студентов и их мотивации к учебно-профессиональной деятельности. Они позволяют перейти к их активному применению в модельных или реальных ситуациях профессиональной деятельности, что, безусловно, повышает качество подготовки будущих специалистов. 


\section{References:}

1. Аронова Г.А. Методика обучения взрослых: особенности мекционной формы подачи материала по гуманитарным дисципАинам [Эмектронный ресурс] // Фестиваль педагогических идей "Открытый урок»: [сайт]. - 2012. - Режим доступа: http://festival. 1september.ru/articles/513950/

2. Ситуационный анализ, или Анатомия Кейс-метода / под ред. Ю. П. Сурмина. - Киев: Центр инноваций и развития, 2002. -286 c.

3. Современные образовательные технологии: учебное пособие / под ред. Н.В. Бордовской. - 2-е изд., стер. - М.: КНОРУС, 2011. - $432 \mathrm{c}$

4. Ступина С.Б. Технологии интерактивного обучения в высшей школе: учебно-методическое пособие / С.Б. Ступина. Саратов: Издательский центр «Наука", 2009. -52 с. 


\title{
TO THE QUESTION OF PEDAGOGICAL SUPPORT PROFESSIONAL-MORAL SELF-ACTUALIZATION OF STUDENTS HELPING OCCUPATIONS OF HUMANITARIAN PROFILE, WITH THE TRANSITION TO THE BOLOGNA SYSTEM OF HIGHER EDUCATION
}

\author{
Irina Rubina ${ }^{1}$
}

1. Postgraduate student of the Department of preschool and secondary education, Altai state pedagogical Academy, Russia.

\section{Abstract}

The article is devoted to the problems of students ' selfrealization in helping professions (teacher, psychologist, educator), with the transition to the Bologna system of higher professional education. Stress the importance of the moral and axiological component in the system of Russian higher education. Proposed content of pedagogical support professional-moral self-actualization of students in the educational environment, the humanitarian University: the structural-functional model, program implementation, and the conditions of formation.

Keywords: the system of higher education, to help the profession, professional-moral self-actualization, pedagogical support.

Эффективность профессиональной и самореализации будущего специалиста во многом определяется доминирующей в обществе образовательной парадигмой и построенной на ее основе моделью подготовки специалиста. Развитие размичных отраслей науки, доступность информационного пространства и инновационных технологий XXI века задают высокий уровень профессиональной конкуренции и усимивают темп возможных изменений, касающихся всех сфер жизнедеятельности человека и его самореализации. Современный переход от сложившейся еще в советский период системы высшего образования (стандартное пятилетнее, а иногда и иестилетнее обучение, основанное на 
идеологии политехнического характера образования, ориентированное на общественную пользу) к европейским стандартам Болонской системы (прикладной, академический бакалавриат, магистратура, основанные на принятии ответственности за вектор своего развития, ориентированное на индивидуальную успешность) приводит россиян к изменению представцений об образовании и критериях образованности мичности.

Период высшего профессионального образования в России является особым этапом цичностного становления каждого человека, поскольку в этот момент кроме постижения специальных знаний утверждается его нравственная позиция, формируется "нравственное ядро" саморазвития кичности будущего профессионала. При переходе на новую систему возникает некий диссонанс между традиционной направленностью нашего образования на формирование "всесторонне развитой мичности профессионала", компетентного во многих областях, имеющего нравственно-аксиологическую позицию по отношению к проблемам общества, и требованиями нового стандарта "человека-техника". Данный стандарт определяет подготовку "социально заказанного" узкого специалиста (не мичности), обладающего конкретно направленными знаниями и компетенциями, вмадеющего основами наук и главное практическими методами освоения мира. В основу образования заложен субъект с рационалистическим типом мышления, предполагающим рассудочно-прагматическое отношение ко всем сферам человеческой деятельности,

Таким образом, с одной стороны, переход на Болонскую систему образования имеет положительные тенденции, выражающиеся в большей мобимьности студентов, глубоком освоении конкретного предмета профессии (именно с практической стороны), позволяет в более короткие сроки выйти на рынок труда и в случаи ошибочного выбора мегко переучиться. Но с другой стороны, данная модемь, кроме технической стороны, еще не учитывает, что самобытность российского общества и образования отражается в структуре нравственных ценностей, выступающих как предельные высшие смыслы человеческой жизни, имеющие общечеловеческий характер и не существующие 


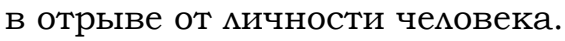

При этом само становление "человеческого в человеке" в процессе гмобализации общественного мирового сознания проходит и так сложный этап, суть которого заключается в противоборстве духовно-нравственных и материальных ценностей саморазвития [2]. Следовательно, необходимо при реформировании нашей системы образования не потерять ее самобытность и мучшие ориентиры советской педагогической мысли, сделать акцент на нравственном саморазвитии в профессии. Это позволит более качественно овладеть выбранной специальностью и добросовестно выполнять свои

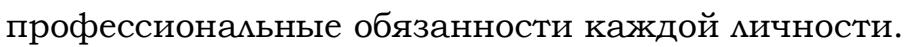

В этом контексте, особого внимания заслуживает ценностно-смысловая подготовка профессионалов гуманитарного профиля (педагог, психолог, воспитатель), способных нравственно самореализовываться как в жизни, так и профессиональной деятельности. Именно они в дальнейшем смогут повысить общее "нравственное качество человеческих ресурсов" (Н.В. Бордовская), так как, объектом и одновременно субъектом их психолого-педагогического труда явцяются живые мюди. K субъектам "помогающих" профессий (helping professions) предъявляются не только требования обычной трудовой морали, но и требования профессиональной нравственности. Поэтому на наш взгляд, новая образовательная парадигма домжна обязательно содержать аспекты активизации профессиональнонравственной самореализации в процессе получения высшего гуманитарного образования, заключенные в особом педагогическом обеспечении образовательной среды.

Профессионально-нравственная самореализация (далее

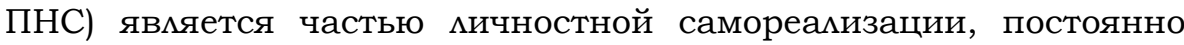
идущим процессом суверенизации мичности субъектов образовательного процесса, за счет формирования профессионально-нравственных качеств и стремления в их саморазвитии. Под ПНС понимается - реализация субъектом своего нравственного потенциала в стремлении к $и$ нностной зрелости и профессиональной идентичности (вершинам профессионализма), за счет профессионально-нравственной активности и ценностно-смыслового отношения к "миру", к "другому", к "себе как мичности и профессионалу". Развитие 
компонентов ПНС требует особого педагогического обеспечения, определяемого как специфический вид профессиональной деятельности, предполагающий активизацию мичностных и институциональных ресурсов, необходимых для реализации эффективности того или иного процесса (А.М. Бочкова, И.А. Гусева, Т.Е. Коровкина, А.И. Тимонин) [1].

Специфика педагогического обеспечения процессов ПНС студентов помогающих профессий состоит в том, что психологопедагогические функции реализуются при переходе от формально-ролевого к ценностно-смысловому взаимосодействию субъектов в квазипрофессиональной деятельности. Педагогическое обеспечение эффективной ПНС студентов помогающих профессий в вузе гуманитарного профиля, на наш взгляд, должно вкАючать:

- внедрение структурно-функциональной модели активизации ПНС в образовательную среду Вуза;

- реализацию программы "Ничему нельзя научить, можно только научиться!», содержащую методику работы с модемью;

- комплекс взаимодействующих между собой организационнопедагогических и психолого-педагогических условий становления ПНС в рамках образовательной среды Вуза.

Структурно-функциональная модель активизаиии ПНС, обоснована социальным заказом общества на нравственно-зрелую мичность, способную реализовывать свой профессиональнонравственный потенциал и имеющую стремление в постоянном самообразовании. Социальный заказ и практическое осмысление деятельности по его реализации, определили цель - активизация процессов саморазвития профессионально-нравственных качеств (ПНК) у студентов помогающих профессий и способности их реамизовывать в будущей профессиональной деятельности. Структуру модели составцяют четыре модуця, построенные в соответствии с этапами развития ПНС, включающие теоретико-методологические подходы, принципы и условия реализации.

Реализация модели подразумевает программу психологопедагогического воздействия "Ничему нельзя научить, можно только научиться!", разделенную на 4 этапа, с конкретно постановленными задачами, функциями, формами, методами и методиками практической работы по активизации ПНС в образовательной среде гуманитарного вуза. Программа содержит следующие блоки: тео- 
ретический, который состоит из двух разделов: первый обеспечивает технологию работы со структурно-функциональной модемью, второй содержит материал для расширения представлений и знаний о ПНС; практический, включает 4 блока с модулями заданий и упражнений; диагностический, содержит показатели ПНС и комплекс диагностических методик. Работа с программой подразумевает реализацию комплекса условий становления ПНС, через осмысление нравственно-аксиологического отношения "к миру", "к другому человеку", "к себе как мичности и профессионалу".

В результате теоретического анализа митературы и практических разработок по проблеме исследования были выдемены следующие условия становления ПНС:

- активизация системообразующих процессов "самости" в континууме (само) - обучения и (само) - воспитания целостного (суверенного) человека, что реализует аккумуляцию индивидуальной системы ценностей и смыслов, запуская тем самым механизмы ПНС;

- опредемение базовых профессионально-нравственных качеств самореализующегося субъекта помогающих профессий (педагог, психолог, воспитатель), их формирование и саморазвитие у студентов в процессе осознания нравственного компонента "образа будущей профессии", что позволяет прогнозировать стратегические и тактические ориентиры в их профессиональнонравственном развитии;

реализация педагогами размичных психологопедагогических позиций и функций (модератора, тьютора, фассилитатора, консультанта, супервизора), не возможна, без раскрытия профессионально-нравственного потенциала мичности самого педагога, проявцяющегося в его Аичностной зрелости и нравственной активности;

- организация нравственно-насыщенной образовательной среды как открытого саморазвивающегося пространства смыслового взаимодействия и творческой содеятельности.

Таким образом, мы можем сказать, чтобы система российского высшего профессионального образования при переходе на европейские стандарты не потеряла свои исторические нравственно-ориентированные корни, а приобрела только положительный практико-направленный опыт, необходимо особое педагогическое обеспечение этого процесса. 
Реализация

структурно-функциональной

модеми

активизации ПНС позволит студентам помогающих профессий, кроме знания предмета своей профессии, отличаться развитой внутренней мотивацией, ответственностью за профессиональные действия, саморефмексией, субъектностью отношений, эмоциональной чувствительностью $\mathrm{k}$ проблемам другого, системой просоциальных ценностей при открытости новому опыту. Их нравственная направленность будет заключаться в реализации ключевых ценностей, жизненных смыслов как системообразующих основ человекомирных отношений.

\section{References:}

1. Измайлова В. В., Педагогическое обеспечение: сущность и структура понятия. // Ярославский педагогический вестник. 2012 - № 2 - Том II (Психолого-педагогические науки). - С. 11-14.

2. Юревич А. В. Нравственное состояние современного Российского общества. // Психологический журнал. - 2009. - Т. 30. - № 3. - C. 107-117. 


\title{
THE CONCEPT OF MODERNIZATION OF PROMOTING FORMATION OF INFORMATION LITERACY OF STUDENTS OF THE UNIVERSITY OF HUMANITIES IN THEIR FUTURE PROFESSIONAL ACTIVITY
}

\author{
Patimat Abdulaeva ${ }^{1} \&$ Khadigat Abdulaeva $^{2}$
}

1. Associate Professor, Dagestan state medical Academy, Russia.

2. Graduate, Dagestan state pedagogical University, Russia.

\section{Abstract}

In given article scientifically well-founded search of a course for choice in the field of information which would form information culture $(И К)$ is considered, integrated all pressing questions of pedagogics of information-educational systems; designing of the maintenance and a technique of this course, the medical students directed on preparation for use of Infokommunitsionnyh of technologies in their future professional work.

Keywords: information, model of training, Internet technology, information culture, self-education, the Internet and medical education.

Новые социально-экономические условия актуализируют необходимость реформирования отечественного образования, так как именно подрастающее поколение в самом ближайшем будущем будет определять перспективы развития российского государства и общества. Основная цель современного образования формирование новой образовательной системы, признанной стать основным инструментом социокультурной модернизацией российского общества [1, с. 35].

Об изменении роли профессионального образования в российском обществе можно судить и по основным позициям российской образовательной политики, зафиксированным в Законе Российской Федерации "Об образовании", раскрытым в Национальной доктрине образования в Российской Федерации до 2025 
года, Концепции модернизации российского образования на период до 2010 года [2, с. 30].

Целью нашего исследования является научно обоснованный поиск курса по выбору в области информатизации, которые бы формировали информационную культуру (ИК), интегрировали все актуальные вопросы педагогики информационнообразовательных систем; проектирование содержания и методики этого курса, направменных на подготовку студентов-медиков к использованию ИКТ в их будущей профессиональной деятельности.

Одной из доминирующих проблем современного высшего образования является проблема проведения комплекса научнопедагогических исследований, посвященных вопросам внедрения и использования в образовательном процессе инновационных технологий, в частности, Интернет-технологии.

Анализ научных исследований и педагогической практики в профессиональной подготовке будущих специалистов позволил нам выделить ряд противоречий:

- между потребностью практики в новых инновационных формах применения Интернет-технологий в учебном процессе вуза и традиционными видами учебно-методического обеспечения;

- между отсутствием общего подхода к использованию Интернет-технологии в обучении студентов и процессом информатизации профессионального образования;

- между поиском актуальной информатизации и её обнаружением необходимой дмя организации учебного процесса, которая позволит повысить эффективность процесса профессиональной подготовки будущих специалистов.

Указанные противоречия заставляют образовательные учреждения, прежде всего, формировать умение учиться, добывать информацию, извлекать из нее необходимые знания.

ДАя развития информационной культуры будущего врача процесс обучения в вузе необходимо организовать так, чтобы он стимулировал погружение студентов в работу с информацией, побуждал их сознательно формировать и развивать навыки работы с информацией. 
Из множества педагогических условий использования Интернет-Технологии в процессе подготовки студентов на дисциплинах гуманитарного профиля нами выбраны следующие:

1. Использование в процессе обучения тех функций Интернет-Технологии, которые отражают особенности гуманитарных дисциплин.

2. Создание позитивной мотивации использования Интернет-Технологии в процессе подготовки будущих врачей.

3. Взаимосвязь Интернет-Технологии с традиционными средствами обучения.

При разработке курса учитывались задачи, ориентированные на общеобразовательный уровень студентов, с интересным и понятным дия них содержанием. Все задания по самостоятельной работе, задания к практическим занятиям содержали в себе работу с Интернет-технологиями; выполнялись последовательно, что позволимо приобрести студентам устойчивые навыки работы с востребованными в их профессиональной области Интернеттехнологиями. Моделируя содержание учебного материала процесса обучения студентов-медиков, мы ставили основной задачей адаптацию содержанию к содержательным возможностям Интернет-технологии. В этой связи предварительным условием моделирования содержания учебного материала является его структурирование, то есть расчиенение на составные эмементы и их могизация, что в свою очередь способствует упорядочиванию всего процесса обучения студентов-медиков гуманитарным дисципминам на основе Интернет-Технологии.

При разработке курса по выбору «Интернет-технологии в медицинском образовании" мы исходими из следующих положений:

- курс должен носить общекультурный характер, развивать могическое и аналитическое мышление студентов, расширять их кругозор в сфере проблем информационного характера;

- при получении медицинского образования навыки систематизации информации и развитие системного мышления играют очень важную роль и данный курс, должен был этому способствовать;

- должен быть началом социологического, психологического и управленческого мониторинга с целью получения целостного представцения о мичности студента [3, с. 318]; 
- технологические вопросы данного курса в первую очередь должны быть ориентированы на формирование умений студентов к использованию технологий поиска информации в базах, данных в глобальной компьютерной сети-Интернет.

В качестве реализации педагогических условий использования Интернет-технологии в процессе изучения студентамимедиками нашего курса по выбору использовалось проблемномодумьное обучение.

Основная задача разработанной нами курса по выбору направлена на подготовку студентов к использованию Интернеттехнологии в профессиональной деятельности.

Информационная направленность способствует формированию информационной грамотности, а культурологическая формированию мировоззрения, пониманию информационных процессов, происходящих в современном обществе, самоопредемению в культуре [4, с. 119].

Основным средством реализации модульного обучения явмяется учебный эмемент. При создании учебных элементов нашего курса по выбору "Интернет-технологии в медицинском образовании" их содержание бымо опредемено таким образом, чтобы каждый из них представлял, с одной стороны, законченную единицу деятельности, необходимую для студента-пользователя компьютера, с другой, быц взаимообусловлен другими учебными единицами.

Построение курса по выбору на основе учебных эмементов удобно потому, что студенты могут работать в индивидуальном темпе, а это в свою очередь, создает возможность формирования самостоятельности в работе с Интернет-Технологиями.

\section{References:}

1. Известия Азербайджанского государственного Педагогического университета. Баку - № 2 - 2011г. 408 с.

2. Модернизация системы непрерывного образования: Материалы II-ой Международной научно-практической конференции. - Дербент: ДГПУ, 25-27 июня 2010 г. - 501 с.

3. Модернизация системы непрерывного образования: Материалы международной научно-практической конференции. Махачкала, 26-28 июня 2009 г. - 425 с. 
4.Модернизация системы непрерывного образования: сборник материалов III Международной научно-практической конференции. / Под общей ред. профессора Т.Г.Везирова. - Дербент. 2011. -263 c. 


\title{
LEADING CONCEPTS OF FORMATION OF PROFESSIONAL AND PEDAGOGICAL COMPETENCE OF FUTURE TEACHERS OF THE HIGHEST AGRARIAN EDUCATIONAL INSTITUTIONS
}

\author{
Aleksandr Yevsyukov ${ }^{1}$
}

1. Candidate of pedagogical sciences, associate professor, Kharkov National Agrarian University named after V.V. Dokuchaev, Ukraine.

\section{Abstract}

In article the short comparative analysis between the traditional znaniyevo-focused and competence-based approach is carried out. The principles are allocated at realization of competencebased approach, such as: variability of education, education centration on development and self-development of the personality, a combination of autonomy to collective and group forms of the education, unstable dynamic balance of educational process as source of development of interrelation of the personality, development of the personality, education and activity.

Keywords: competence-based approach, professional and pedagogical competence, principles, abilities, knowledge, personal qualities, valuable reference points, future teacher, the highest agrarian educational institution.

В настоящее время концепция обучения в течение всей жизни приобрела доминирующее значение в мировой образовательной практике. В качестве основного инструмента реализации концепции декларируется компетентностный подход, который позволяет вывести образование за рамки общего профессионального.

На современном этапе развития педагогической науки и практики, компетентностный подход рассматривается как совокупность общих принципов опредемения целей обучения, отбора содержания образования, организации образовательного процесса и оценки образовательных результатов. Определение сущности компетентносного подхода требует от нас сравнительного анализа 
основных его идей с идеями традиционных подходов для высшего аграрного образования.

Современные исследователи компетентностного подхода (И.А. Зимняя, В.В. Сериков, А.В. Хуторской) утверждают, что он явцяется гуманитарным по своей природе, так как напрямую связан с идеей всесторонней подготовки и воспитания индивида не только в качестве специалиста, профессионала своего дела, но и как мичности и члена комлектива и социума. Цемью гуманитарного образования, по В.В. Серикову, явцяется не только передача студенту совокупности знаний, умений и навыков в определённой сфере, но и развитие кругозора, междисципиинарного чутья, способности к индивидуальным креативным решениям, к самообучению, а также формирование гуманистических ценностей [1].

В рамках компетентностного подхода рассматриваемой на-

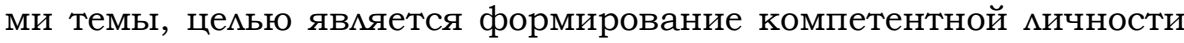
будущего преподавателя высшего аграрного учебного заведения,

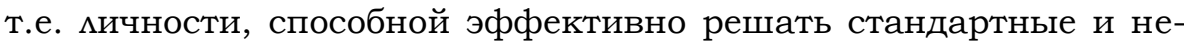
стандартные учебные и профессиональные проблемы. Гцавное отмичие компетентностной модели целеполагания в образовательных системах от традиционной знание - ориентированной в том, что она ориентирована на междисциплинарные, интегрированные требования к результату образовательного процесса [2].

Так, принципиальные размичия между традиционным знаниево - ориентированным и компетентностным подходом возникают по всем значимым критериям определения целей высшего аграрного образования (исходные основания, назначение знаний и умений, виды деятемьности, характер жизненных ориентиров, основной результат).

Однако, признавая принципиальные разцичия в методолого - теоретических основаниях данных подходов, некоторые исследователи (И.А. Зимняя, О.Е. Иванова и др.) высказывают мнение о том, что компетентностный подход не отрицает знание - ориентированного, а углубляет, расширяет и дополняет его, вкцючая как обязательный эмемент субъектности будущего специалиста [3, 4].

Результаты краткого сравнительного анализа позволяют нам утверждать, что компетентностный подход бомее соответствует условиям современного высшего аграрного образования, ибо он 
предполагает ориентацию на формирование наряду с профессиональными знаниями, умениями и навыками, трактуемыми как владение профессиональными технологиями, еще и развитие у будущих преподавателей таких универсальных способностей и готовностей (компетенций), которые востребованы современной высшей аграрной школой. Вместе с тем, специфика реализаций компетентностного подхода предполагает перенос акцентов на воспитательную и развивающую функции образования, на становление в процессе обучения мичности будущего преподавателя, его гармоничное духовное и нравственное развитие, высокую психологическую устойчивость и готовность к учебновоспитательному процессу.

Так, выбор компетентностного подхода в качестве методомогического основания формирования профессиональнопедагогической компетентности будущих преподавателей высших аграрных учебных заведений продиктован следующими поможениями:

- образовательный результат "компетентность" в большей степени соответствует общей цели формирования профессионально-педагогической компетентности - подготовка преподавателя, способного к активной социальной адаптации, самостоятельному жизненному выбору, к культуросообразному осуществмению профессионально-педагогической деятельности, профессиональному саморазвитию и самосовершенствованию;

- в нем соединяются ценностно-мотивационная, когнитивная, деятельностная и эмоциональная составцяющая, что отвечает нашим представмениям о содержании формирования профессионально-педагогической компетентности будущих преподаватемей высших аграрных учебных заведений;

- "профессионально-педагогическая компетентность" будущих преподавателей высших аграрных учебных заведений как целевой ориентир предполагает существенные изменения не только в содержании образования, но и в способах его освоения, а, значит, в организации всего образовательного процесса в це$\Lambda \mathrm{OM}$;

- содержание образования в организуемом процессе должно строиться по критерию результативности, что выходит за границы ЗУНов; 
- компетентностный подход обцадает ярко выраженной интегративностью, объединяя в единое цемое соответствующие умения, знания, цичностные качества, ценностные ориентиры, обеспечивающие культуросообразную деятельность будущего специамиста.

В качестве основных при реализации компетентностного подхода в профессиональном образовании Г.М. Романцев, Е.В. Ткаченко, Э.Ф. Зеер, выделяют принципы: вариативности образования, центрации образования на развитии и саморазвитии мичности, сочетание автономности с комлективными и групповыми формами образования, неустойчивого динамического равновесия образовательного процесса как источника развития взаимосвязи мичности, соразвития Аичности, образования и деятельности. Остановимся на их характеристике [5].

Приниип вариативности образования определяется многообразием и мобильностью социума, необходимостью адаптации к динамичному миру профессий, максимахьного учета индивидуальных особенностей обучаемых, обеспечения их автономности и построения индивидуальных образовательных маршрутов.

Принии иентраиии образования на развитие и саморазвитие личности подразумевает, что главным источником психологических новообразований является сама мичность. В педагогической психологии основным фактором формирования психологических новообразований признается ведущая деятельность. Применительно к профессиональному образованию в качестве ключевого фактора рассматривается сама кичность, ее самоактуализация. Важное значение приобретает учет возрастных особенностей обучаемых на разных ступенях профессионального образования.

Согмасно приниипу сочетания автономности с коллективнъми и групповыми формами образования, индивидуализированное обучение создает условия дмя самоопредемения и самореамизации обучаемых, групповое обучение формирует у них способности к сотрудничеству, рефмексии, комлективной ответственности, корпоративную культуру в целом.

Приниип неустойчивого динамического равновесия образовательного проиесса как источника развития взаимосвязи личности, образования и профессии основан на том, что исходным моментом цюбого развития явцяется спектр индивидуальных 
противоречий и действий. Без неустойчивости нет развития. Только системы, далекие от равновесия, находящиеся в состоянии неустойчивости, способны спонтанно организовывать себя и развиваться.

Приниип соразвития личности, образования и деятельности в профессионально-образовательном пространстве человека основывается на признании двух форм бытия: возможного и действительного. Продуктивность формирования культуры профессиональной деятельности будущего специалиста во многом зависит от мичностно-профессионального потенциала человека, объективных и субъективных возможностей его реализации в образовании и профессии.

Выделенные принципы, на наш взгляд задают общую рамку организации образовательного процесса на основе компетентностного подхода.

В контексте формирования профессиональнопедагогической компетентности будущих преподавателей высших аграрных учебных заведений нам близка позиция О.Е. Аебедева, который выделяет следующие принципы реализации компетентностного подхода:

1. Смысл профессионального образования, заключается в развитии у будущих специалистов способности самостоятельно решать проблемы в различных сферах и видах деятельности на основе использования социального и культурного опыта, эцементом которого явцяется и собственный опыт студентов.

2. Содержание образования выступает как дидактически адаптированный опыт, включающий знания, нормы, ценностный опыт культуротворческой деятельности, способы решения познавательных, мировоззренческих, нравственных, культурных, профессиональных и иных проблем.

3. Организация образовательного процесса должна быть направлена на создание условий для формирования у обучающихся опыта самостоятельного решения познавательных, коммуникативных, организационных, нравственных, профессиональных и иных проблем, составцяющих содержание будущей профессиональной деятельности.

4. Оценка образовательных результатов основывается на анализе уровней компетентности, достигнутом студентами на определенном этапе обучения [6]. 
Проведенный анализ теоретических оснований реализации компетентностного подхода позволяет нам утверждать, что в процессе формирования профессионально-педагогической компетентности будущих преподавателей высших аграрных учебных заведений компетнтностный подход предполагает интеграцию организуемого учебно-воспитательного процесса и его осмысления, в ходе которого и происходит формирование рассматриваемого качества будущего специалиста и ценностного отношения $\mathrm{K}$ предмету своей деятельности. Основная идея подхода в этом контексте заключается в том, что результатом формирования профессионально-педагогической компетентности будущих преподавателей высших аграрных учебных заведений выступает их готовность к эффективной и продуктивной деятельности в разАичных учебно-воспитательных и профессионально значимых ситуациях. В связи с этим на первый план в организуемом процессе выступает не столько наращивание знаний, сколько приобретение разностороннего опыта профессионально-педагогической деятельности.

\section{References:}

1. Сериков В.В. Аичностный подход в образовании: концепция и технология: монография / В.В. Сериков.- Волгоград: Перемена, 1994. -152 с.

2. Байденко В.И. Базовые навыки (ключевые компетенции) как интегрирующий фактор образовательного процесса / В.И. Байденко, Б. Оскарсон // Профессиональное образование и формирование мичности специалиста.- М., 2002. -С 22-46.

3. Зимняя И.А. Компетентность человека - новое качество результата образования / И.А. Зимняя. - http://www.bigpi. biysk.ru.

4. Иванова Е.О. Компетентностный подход в соотношении со знаниево-ориентированным и культурологическим / Е.О. Иванова // Компетенции в образовании: опыт проектирования.-М.: ИНЭК, 2007.- С.71-78.

5. Теория и практика профессионально-педагогического образования: коммектив: монография / Г.М. Романцев. Екатеринбург: Из-во ГОУ ВПО РГППУ, 2007.- 305 с.

6. Аебедев О.Е. Компетентностный подход в образовании / О.Е. Аебедев // Шк. технологии.- 2004.- №5. -С. 3-12. 


\title{
TECHNOLOGICAL APPROACH TO FORMATION OF PROFESSIONAL AND PEDAGOGICAL COMPETENCE OF FUTURE TEACHERS OF THE HIGHEST AGRARIAN EDUCATIONAL INSTITUTIONS
}

\author{
Aleksandr Yevsyukov ${ }^{1}$
}

1. Candidate of pedagogical sciences, associate professor, Kharkov National Agrarian University named after V.V. Dokuchaev, Ukraine.

\section{Abstract}

In article the analysis of various approaches of leading scientists-teachers to a question of technology of training is carried out. The main definitions of technology of the training, allowed to draw a conclusion are considered that technological approach serves as an indispensable condition of improvement of quality of education, improvement of its contents and as a result of it is formation of professional and pedagogical competence of future teachers of the highest agrarian educational institutions.

Keywords: technological approach, technology of training, formation, professional and pedagogical competence, undergraduate, future teacher, the highest agrarian educational institution.

Достичь нового качества подготовки будущих преподаватемей высших аграрных учебных заведений в современных условиях модернизации высшей школы представляется возможным при переходе от дисциплинарной системы обучения $\mathrm{k}$ технологической, которая характеризуется, прежде всего, профессиональноориентированным подходом, предоставцяющем возможность будущим преподавателям через детальную разработку и осуществмение проекта учебной дисциплины реализовывать собственные профессиональные интересы и нести персональную ответственность за свои творения. В этом случае на первое место в образовательном процессе выходит профессионально-педагогическая деятельность обучающихся. 
ДАя подготовки будущих преподавателей высших аграрных учебных заведений, на наш взгляд, такой подход является наибомее продуктивным, так как в процессе разработки проекта магистранты по специальности "Педагогика высшей школы" постигают все особенности педагогического труда, связанные с целями, задачами, объектом, способами осуществления и его результатом. А это значит, что разработка проекта протекает в пространстве Аичностного и профессионального опыта. Задача его еще и в том, чтобы отделить Аичное от объективных достоинств или недостатков обсуждаемого предмета, так сказать, значение от смысла. Эта дивергенция значений и смыслов придает особое качество проекту: в нем "гуманитарное»- рефмексия собственной позиции профессионала, ее могико-вербальное изможение органически сочетается с когнитивным, исследовательским отношением к разрабатываемой проблеме. Эта особенность проекта делает технологию обучения развивающей.

Исходя из сказанного, профессионально-ориентированная технология обучения позволяет значительно повысить степень осмысленности учебного материала за счет:

- изменения структуры учебного материала, под которой подразумеваются связи между эмементами изучаемого материама;

- организации активных видов познавательной деятельности обучающихся в контексте овмадения профессией;

- изменения роли преподавателя. Преподаватель перестает быть единоличным хранителем истины и знаний. На его долю выпадает роль руководителя проекта и колмеги, на смену авторитарной педагогике приходит педагогика сотрудничества.

Дия формирования профессионально-педагогической компетентности будущих преподавателей высших аграрных учебных заведений, такая организация обучения требует соответствующей технологии. В связи с этим необходимо:

- определить ведущую цель каждой учебной дисциплины в магистратуре по специальности "Педагогика высшей школы";

- выявить наиболее значимые профессиональные задачи, решаемые на основе знаний, получаемых по конкретной дисципмине;

- определить с учетом этого целесообразную структуру учебного курса, удельный вес каждой его части; 
- разработать соответствующую систему практических задач и заданий.

В разработку проблемы технологии обучения наибольший вклад внесли учёные-педагоги С.Я. Батышев, В.П. Беспалько, В.Н. Боголюбов, А.А. Вербицкий, М.В. Кцарин, Н.В. Кузьмина, М.М. Аевина, П.И. Образцов, Һ.Г. Семушина, М.П. Сибирская, В.А. Сластенин, С.А. Смирнов, Ю.Г. Татур, А.И. Уман, О.Н. Фиматов, Д.В. Чернимевский, М.А. Чошанов, и другие. Из зарубежных исследователей следует отметить $\Lambda$. Андерсона, Дж. Блока, Б. Блума, Ф. Кумбса, Дж. Кэромла, Р. Мейджера и др. Далеко не всегда взгляды ученых совпадают.

Так, сегодня значительное число педагогов-исследователей М.Я. Вименский, С.А. Смирнов, П.И. Образцов, А.И. Уман, О.К. Филатов, Д.В. Чернилевский и др. сходятся на том, что с технологической точки зрения применение терминов "технология воспитания", "технология развития", "образовательная технология" и т.п. в области воспитания и развития цичности часто явцяется некорректным. Аргументируя это тем, что до настоящего времени в современной педагогике однозначно не выявлены критерии оценки воспитанности человека, сформированности у него определенных качеств Аичности, ценностных ориентаций и других результатов воспитания и развития человека.

Соглашаясь с мнением П.И. Образцова [1], полагаем, что отмичие методики обучения от технологии состоит в том, что первая отвечает на вопрос: "Каким путем можно достичь требуемых результатов в обучении?», а вторая - «Как сделать это гарантированно?». При этом технология обучения носит ярко выраженный персонифицированный характер и по своей сути очень близка понятию авторская методика обучения. Если понятие "методика" выражает процедуру использования комплекса методов и приемов обучения, как правило, безотносительно к деятелю, их осуществляющему, то технология обучения предполагает присовокупмение к ней мичности преподавателя во всех ее многообразных проявлениях. Таким образом, технология обучения неразрывно связана с педагогическим мастерством педагога. Совершенное владение ею и есть мастерство.

Далее считаем, целесообразным уточнить понятийнокатегориальный аппарат, используемый в настоящем исследовании, в связи с обращением к категории "технология обучения". 
Приведем некоторые опредемения понятия технологии обучения, встречающиеся в работах названных авторов.

Впервые понятие "технология обучения" введено на конференции ЮНЕСКО в 1970 г. и в общем смысле рассматривалось как системный метод создания, применения и опредемения всего процесса преподавания и усвоения знаний с учетом технических и человеческих ресурсов, их взаимодействия, ставящей своей задачей оптимизацию форм образования. Однако с тех пор данное понятие претерпемо изменение.

Ф. Кумбс включает в это понятие «самые различные методы, материалы, оборудование и систему снабжения - словом, все, что участвует в учебном процессе и способствует развитию системы образования" [2].

М.M. Аевина понимает под технологией обучения "теоретический проект педагогического управления учебной деятельностью и систему необходимых средств, обеспечивающих функционирование педагогической системы согласно заданным целям образования и развития учащихся" [3, с. 20].

$\Lambda . Г$. Семушина определяет технологию обучения как способ реализации содержания обучения, предусмотренного учебными программами, включающей в себя систему форм, методов и средств обучения, благодаря которым обеспечивается наиболее эффективное достижение тех или иных поставценных целей. [4, c. 91].

М.А. Чошанов [5] указывает на то, что технология обучения - это составная процессуальная часть дидактической системы.

Исследователи организации процесса обучения в высшей школе Д.В. Чернилевский и О.Н. Филатов [6] предможили следующее опредемение: "Технология обучения - это системный комплекс психолого-педагогических процедур, включающий специальный набор и компоновку дидактических форм, методов, способов, приемов и условий, необходимых дмя процесса обучения".

Как видим, авторы стремятся к системному представлению педагогического процесса. Большинство исследователей сходятся на том, что технология обучения связана с определенным построением и реализацией учебного процесса, направленного на получение гарантированного результата (достижение дидактических цемей). 
При этом, как отмечают ученые В.А. Сластенин, С.А. Смирнов, П.И. Образцов достижение гарантированных дидактических целей обучения возможно при применении соответствующих средств. "Высокая производительность средства обучения и особенности их использования создают совершенно иную модель обучения, иную культуру образовательного процесса" [1, с. 11]. Следовательно, средства обучения в учебном процессе выступают в качестве одной их важных характеристик реализации технологии обучения.

Проведенный анализ современной научной митературы свидетельствует о том, что многие авторы относят к ним: системность, научность, интегративность, воспроизводимость, эффективность, качество и мотивированность обучения, новизну, алгоритмичность, информационность, возможность тиражирования и переноса в новые условия и др.

Такое многообразие характеристик требует выделить некий обобщенный инвариантный признак технологии обучения, отражающий ее сущность. В качестве такового П.И. Образцов, В.А. Сластенин, С.А. Смирнов, А.И. Уман и др. предлагают определять - законосообразность технологии. Ведь технология обучения - это, прежде всего, педагогический процесс, максимально реализующий в себе дидактические законы и закономерности, и, благодаря этому, обеспечивающий достижение конкретных конечных результатов. Чем полнее постигнуты и реализованы эти законы и закономерности, тем выше гарантия получения требуемого результата. Таким образом, критерию законосообразности должны отвечать все ведущие признаки технологии обучения.

Поэтому в целях решения задач, определенных в настоящем исследовании, опираясь на подход, предможенный П.И. Образцовым, будем исходить из того, что технология обучения - это законосообразная педагогическая деятельность, реализующая научно обоснованный проект дидактического процесса и обладающая более высокой степенью эффективности, надежности и гарантированности результата, чем это имеет место при традиционных моделях обучения.

Это базовое опредемение может быть модифицировано в тех значениях, когда технология обучения выступает как процесс и результат.

С точки зрения процесса технология обучения может рас- 
сматриваться как "последовательность педагогических процедур, операций и приемов, составляющих в совокупности целостную дидактическую систему, реализация которой в педагогической практике приводит к достижению гарантированных целей обучения, т.е. обеспечивает достижение прогнозируемого результата обучения в изменяющихся условиях образовательного процесса и способствует целостному развитию мичности обучающегося" [1].

В этом случае система взаимосвязанных действий педагога направлена на решение дидактических задач и планомерное, последовательное воплощение на практике заранее спроектированного педагогического процесса.

Технология обучения (как результат) представляет собой научный проект (описание, модель) дидактического процесса, воспроизведение которого гарантирует успех педагогических действий [1].

Учитывая тот факт, что процесс обучения в магистратуре по специальности "Педагогика высшей школы" направцен на подготовку будущих преподавателей высших учебных заведений, в том числе и аграрных, принципиально важным становится в качестве критериев деятельности педагога на технологическом уровне выдемить следующие:

- наличие четко и диагностично заданной цели, т.е. корректно измеряемого представления понятий, операций, деятельности магистрантов как ожидаемого результата обучения, способов диагностики достижения этой цели;

- представление изучаемого содержания в виде системы познавательных и практических задач, ориентировочной основы и способов их решения;

- наличие достаточно жесткой последовательности, цогики, опредеменных этапов усвоения темы (материала, набора профессиональных функций и т.п.);

- указание способов взаимодействия участников учебного процесса на каждом этапе (преподавателя и магистрантов, магистрантов друг с другом);

- использование преподавателем наиболее оптимальных, с точки зрения результативности учебного процесса, средств обучения;

- мотивационное обеспечение деятельности преподавателя и магистрантов, основанное на реализации их мичностных функ- 
ций в этом процессе (свободный выбор, креативность, состязательность, жизненный и профессиональный смысл);

- указание границ правилосообразной (алгоритмической) и творческой деятельности преподавателя, допустимого отступления от единообразных правил.

Обобщая сказанное выше, обоснуем сущность технологического подхода к обучению будущих преподавателей высших учебных заведений, которая заключается:

- в предварительном проектировании учебного процесса с последующей возможностью воспроизведения этого проекта в педагогической практике;

- в специально организованном целеобразовании, предусматривающем возможность объективного контроля качества достижения поставленных дидактических целей;

- в структурной и содержательной целостности технологии обучения, то есть в недопустимости внесения изменений в один из ее компонентов не затрагивая другие,

- в выборе оптимальных методов, форм и средств, диктуемых вполне определенными и закономерными связями всех эмементов технологии обучения;

- в наличии оперативной обратной связи, позволяющей своевременно и оперативно корректировать процесс обучения.

Таким образом, технологический подход служит непременным условием повышения качества образования, совершенствования его содержания и как следствие этого - формирование профессионально-педагогической компетентности будущих преподавателей высших аграрных учебных заведений. В рамках профессионально-ориентированной технологии обучения процесс усвоения теоретических знаний, формирование профессионально-педагогических умений и качеств Аичности будущих преподавателей высших аграрных учебных заведений представцяется возможным в условиях создания и реализации магистрантами проекта учебной дисциплины, который становится средством достижения цели овмадения профессионально-педагогической компетентностью. Магистрант овладевает технологией превращения знаний и способов деятельности всех разделов образовательно-профессиональной программы в средство решения профессионально-педагогических задач. 


\section{References:}

1. Виленский В.Я., Образцов П.И., Уман А.И. Технологии профессионально-ориентированного обучения в высшей школе: Учебное пособие / Под ред. В.А. Сластенина. - М.: Педагогическое общество России. - 2004. - 275 с.

2. Кумбс Ф. Кризис образования в современном мире. - М., 1970. - с.130.

3. Аевина М.М. Технологии профессионального педагогического образования. - М.: Издат. центр "Академия", 2001. - 272 с.

4. Семушина А.Г., Ярошенко Н.Г. Содержание и технологии обучения в средних специальных учебных заведениях: Учеб пособие дмя преп. Учреждений сред проф. образования. - М.: Мастерство, 2001. - 272 с.

5. Чошанов М.А. Дидактические конструкции гибкой техномогии обучения / /Педагогика. - 1997. - № 2.

6. Чернилевский Д.В., Фиматов О.К. Технологии обучения в высшей школе. / Под ред. Д.В. Чернилевского. - М.: "Экспедитор", 1996. - 228 с. 


\title{
THE FORMATION OF LISTENING SKILLS IN THE LEARNING PROCESS
}

\author{
Galina Zelenova ${ }^{1} \&$ Tatiana Vasilyeva $^{2}$
}

1. Candidateof pedagogical Sciences, Volgodonsk Institute of Service (branch) of the Don State Technical University, Russia.

2. The teacher of school №2 settlement Juzhniy, student Volgodonsk Institute of service (branch) of the Don State Technical University, Russia.

\section{Abstract}

The article considers the nature and specificity of the hearing process, the factors influencing on the efficiency of speech perception, didactic conditions ensuring the formation of listening skills in the learning process.

Keywords: the process of learning, skill, hearing, auditory attention, product of hearing, interaction.

Одним из наиболее важных качеств педагога является коммуникабельность, т.к. непосредственное общение с обучающимися, их родителями, колмегами является неотъемлемой частью его работы. От этого зависит насколько успешной и продуктивной будет их профессиональная деятельность.

Древнегреческий мыслитель Пиутарх (ок. 45-ок. 127) отмечал, что нужно научиться слушать и тогда можно извлечь пользу даже из тех, кто пцохо говорит [1, 43].

При кажущейся простоте, способность и умение эффектив-

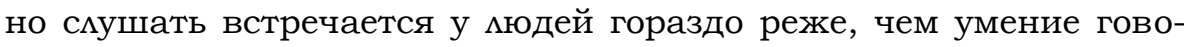
рить. На первый взгляд может показаться что умение слушать присуще каждому нормальному человеку от рождения, если его речь и слух полноценны. Однако психологией установцено, что задуманное сообщение в процессе изложения значительно искажается. Слушание и передача информации цюдьми друг другу похожа на детскую игру "Испорченный телефон". Становится понятным, что масса недоразумений происходит на практике 
именно потому, что не умеем слушать наших собеседников, не пытаемся понять переживаемые ими чувства. Слушание - активный и трудный процесс. Оно предполагает внимание к тому, кто и как говорит и о чем идет речь. В разных науках накоплен достаточный материал для исследования. Более всего в экономике, где есть руководство дия крупных предпринимателей, как надо слушать подчиненных (И. Атватер, М.Н. Ночевник, В. Аимонаев, Е.Я. Мелибруда, А. Моль и др.) Однако педагоги данной проблеме посвятили мало работ, она является малоизученной, хотя и выступает очень важной в диалогическом общении.

Слушание - это сложный психический процесс непосредственного отражения опосредованных языком связей и отношений предметов и явлений окружающей действительности, выраженных в речевом сообщении.

Цель слушания, реализуемая в его предмете, в осмыслении поступающей на слух речевой информации, воспроизводимой говорящим. Следовательно, аналитико-синтетическая составмяющая деятельности представлена в слушании более полно и развернуто, чем в говорении.

Специфичность скушания отражается и в характере его результата, который, с одной стороны, реализуется в понимании или непонимании речевого сообщения, a, с другой стороны, реамизуется в другом виде деятельности того же человека (в отличие от говорения, результат которого выявцяется в деятельности других мюдей). Чаще всего в речевом общении коммуникативным результатом слушания является ответное говорение. Продукт слушания представляет собой то умозаключение, к которому пришел человек в результате слушания.

На эффективность протекания этого процесса вцияет достаточно много факторов: и уровень культуры собеседников, и степень их заинтересованности проблемой, друг другом, исходом беседы, возраст и пол собеседников и многое - многое другое.

В дидактике предполагается учет, прежде всего таких особенностей учащихся, которые вмияют на учебную деятельность и от которых зависят результаты учения. Следовательно, важны такие индивидуальные особенности, которые оказывают влияние на восприятие и понимание речи, что обеспечивает эффективность контакта педагога и обучающегося, успешность усвоения учебного материала. K индивидуальным особенностям обучаю- 
щихся относятся разиичные физические и психические качества и состояния мичности: особенности познавательных процессов, свойства нервной системы, черты характера, воля, мотивация, способности, постоянные или временные дефекты органов чувств и всего организма. Существенное влияние на учебную деятельность оказывают и влияние разцичных социальных факторов.

С чего начинать обучение умению слушать? Вероятно, начинать надо по - разному, в зависимости от знания того, какой в наличии имеется запас знаний и мичного опыта в этом отношении, т.е. с диагностики. Чтобы научить и научиться слушать, необходимо, прежде всего, проанализировать и выявить уже имеющийся уровень умения слушать. В качестве диагностических методик используются: анкеты, опросники, тесты, и т.д., а также набцюдение, которое педагог ведет постоянно в процессе взаимодействия с обучающимся и учитывает его результаты при планировании и проведении занятий.

Самый ценный и в тоже время наиболее уязвимый компонент аудирования - является слуховое внимание. Различные аспекты внимания - его объем, устойчивость, переключаемость, интерферируемость - в конечном итоге проявляются в интегральном результате эффективного аудирования. Если у слушающего неустойчивое внимание, то вряд $\Lambda и$ можно ожидать хороших результатов аудирования. Существует много способов и приемов, по разному влияющих на слушателей и педагог должен не только их знать, но и в совершенстве владеть. Еще в античности была признана важность вступления к речи, которое применяли для установцения контакта со слушателями. В курсе химии, один из первых уроков начинаем с рассказа о великом французском уче-

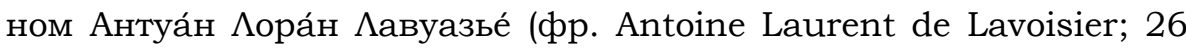
августа 1743 г., Париж - 8 мая 1794 г.) - основателе современной химии. Подобных примеров можно привести много. По сути, каждый урок можно и нужно начинать мибо с рассказа, мибо с эпиграфа, цитаты, мибо с чего-то интересного, увиденного ими услышанного, относящегося к теме.

В последующем изложении учебного материала, очень важно проблемно-эвристическое начало, способствующее творческому взаимодействию. Сама тема занятия домжно вызывать интерес, тем более на современном этапе, когда учитель определяет и формулирует ее самостоятельно. Очень важно проблему препод- 
нести таким образом, чтобы необходимость ее решения осознавамась как потребность педагога и обучающегося, чтобы результатом было мичностно важное открытие. И для этого на уроках химии достаточно возможностей.

Педагог, поставив перед собой опредеменную дидактическую задачу, всякий раз должен детально анализировать оптимальные речевые пути ее решения, преодолевая коммуникативный дискомфорт.

Привлекают внимание обучающихся и мнемонические приемы. Например: Сапоги мои того, пропускают Н2О.

Слушать трудно. Обучающийся может не прислушиваться к словам педагога, а только делает вид, что слушает. Ведь может так случится, что он в данный момент обдумывает, что ему демать на перемене, или после уроков. Если не слушает кто-то один - педагог или обучающийся - это уже не коммуникативная ситуация. Бывает, что слушают внимательно, а бывает, что вполуха. И время от времени может отвлекаться.

Одним из дидактических условий, обеспечивающих формирование умения слушать, является опора на образные впечатления при слушании на основе слуховых ассоциаций. Формирование умения слушать должно осуществляться в двух органично связанных формах: цогической и чувственно-образной, так же как и познание предметов и явлений окружающего мира. На уроках по всем дисциплинам должно формироваться соответствующее отношение к родному языку. При формировании умения слушать, наряду с образной, эмоциональной речью учителя, необходимо практиковаться и в восприятии звукозаписи.

Огромное значение в превращении обучающегося в активного слушателя имеет фактор внезапности, новизны информации, удивления. Все названные факторы способствуют усилению внимания к речи педагога, активизируют процесс слушания. Однако особое значение при восприятии информации имеет использование прошлого опыта обучающегося. Новая информация воспринимается и понимается эффективнее, когда опирается на уже имеющиеся знания, умения и навыки.

Таким образом, без коммуникации, включающим в себя два основных под процесса - слушание и говорение, процесс обучения просто не состоится. Оба процесса, и говорение и слушание сложны и трудоемки, однако условия их реализации различны. 
Сегодня важно формировать не только умение говорить, но и особо важно формировать умение слушать. Процесс обучения необходимо не только на конкретном уроке по конкретной дисципАине, но и в образовательном учреждении строить таким образом, что бы все способствовало формированию умения слушать, т.к. протекание данного процесса практически невозможно увидеть, но именно от его эффективности зависят результаты взаимодействия педагога и обучающегося.

\section{References:}

1. Шеламова, Г.М. Деловая культура и психология общения : учебник для нач. проф. образования / Г.М. Шемамова. - 7-е изд., стер. - М.: Издательский центр "Академия", 2007. - 160 с.

2. Зеленова Г.В. Культура слушания в развитии системы профессионально-педагогического образования. Монография / Г.В. Земенова. - Шахты: ЮРГУЭС, 2004. -103с. 


\title{
REALIZATION OF THE DIAGNOSTIC AND FUNCTIONAL DIRECTION IN THE CONTENT OF SCIENTIFIC AND METHODICAL WORK OF EXPERIMENTAL EDUCATIONAL INSTITUTION
}

\author{
Nataliya Khacayuk ${ }^{1}$ \\ 1. Assistant of the chair of Pedagogy of Taurida National \\ V.Y. Vernadskiy University, Ukraine.
}

\begin{abstract}
In article the maintenance of diagnostiky and the functional direction of scientific and methodical work in experimental educational institution is proved. It is defined structure of readiness of the teacher to experimental and research activity. It is allocated levels of formation of readiness of teachers to experimental and research activity.
\end{abstract}

Keywords: scientific and methodical work, the diagnostikofunctional direction, structure of readiness of the teacher to experimental and research activity.

Содержание научно-методической работы в учебном заведении определяется целью, поставленной перед учителями школы и конкретными задачами, обусловленными анализом деятельности учителей и педагогических комлективов.

Опредемение цели научно-методической работы в экспериментальном учебном заведении связываем с созданием в школе усмовий дмя развития мичности каждого педагога, его готовности к Аюбому, даже непредвиденному будущему, способности адаптироваться к новейшим ситуациям; с развитием системы мотивации педагогических работников к инновационным преобразованиям и формированием готовности учителей к экспериментально-исследовательской деятельности. Формирование учителяисследователя, эффективная подготовка его к экспериментальноисследовательской деятельности осуществляется благодаря созданию в экспериментальном учебном заведении инновационной образовательной среды. 
В современной научно-педагогической митературе понятие "инновационная образовательная среда" рассматривается как комплекс взаимосвязанных условий, обеспечивающих образование педагога, формирование личности человека с инновационнотворческим мышиением, его профессиональную компетентность [1]; "педагогически целесообразно организованное пространство жизнедеятельности, которое способствует развитию инновационного ресурса мичности, интегрированное средство накопления и реализации инновационного потенциала учебного заведения" [3, с. 110]. В контексте исследования под инновационной образовательной средой рассматриваем среду, которая создается в рамках конкретного экспериментального учебного заведения, в котором происходит непрерывное обучение педагогических работников и формируется их инновационный потенциал. Под инновационным потенциалом педагогов понимаем творческую способность учителей к продуцированию новых идей, овладение механизмами экспериментально-исследовательской деятельности, высокий уровень мотивации педагогических работников к инновационным преобразованиям.

Итак, в экспериментальном учебном заведении цель научнометодической работы заключается в создании в школе инновационной образовательной среды, которая обеспечивает постоянный рост инновационного потенциала учителей и уровня профессионального мастерства педагогов.

Содержание научно-методической работы в экспериментальном учебном заведении представлено диагностикофункциональным, информационно-методическим, содержательно-образовательным, поисково-прогностическим и исследовательско-творческим направлениями [2].

Обоснуем содержание диагностико-функционального направления научно-методической работы в экспериментальном учебном заведении.

Суть диагностико-функционального направления заключается, во-первых, в проведении диагностики промежуточных и конечных результатов внутришкольной научно-методической работы и профессиональных затруднений, образовательных потребностей и информационных запросов педагогов; во-вторых, в выявлении содержания, особенностей развития инновационной инициативы в школе; в третьих, в изучении и оценки профессио- 
нальной подготовленности учителя (педагогического комлектива) к экспериментально-исследовательской деятельности. Под готовностью к экспериментально-исследовательской деятельности понимаем интегральное качество педагога, которое состоит из мотивационно-целевой, содержательно-технологической и рефмексивно-прогностической составцяющих, присущих данной цичности и соответствующих определенному уровню сформированности.

Так, мотивационно-целевой компонент является основой для осуществления экспериментально-исследовательской деятельности и проявляется в отношении мичности к этому виду деятельности, в частности в постоянной потребности и собственной целевой направленности к ее осуществлению, творческой самореализации учителя. Творческая самореализация педагога - это включение учителя в педагогическое творчество, осуществление творческих замыслов в решении поставленных задач, которые позволяют Аичности максимально полно реализовать свои способности.

Содержательно-технологический компонент обнаруживает сформированность готовности учителей к эффективной реализации экспериментально-исследовательской деятельности, раскрывается уровнем знаний учителя по основам теории экспериментально-исследовательской деятельности, умениями применять помученные знания на практике и , в результате, выработкой индивидуального стиля экспериментально-исследовательской деятельности.

Сформированность рефмексивно-прогностического компонента отображает умения оценивать учителем собственные мичностные качества и возможности, анализировать собственный стиль экспериментально-исследовательской деятельности осмысмивать, корректировать, прогнозировать и понимать проблемы, которые могут возникнуть в процессе ее реализации.

Структура готовности учителя к экспериментальноисследовательской деятельности представлена в таблице.

На основе соотношения и степени проявцения компонентов готовности учителя к осуществлению экспериментальноисследовательской деятельности выделим уровни сформированности готовности педагогов $\mathrm{k}$ экспериментально- 
исследовательской деятельности: высокий, достаточный, средний и ниже чем средний.

Таблица

Структура готовности учителя к экспериментальноисследовательской деятельности

\begin{tabular}{|c|c|c|}
\hline \multicolumn{3}{|c|}{$\begin{array}{l}\text { Компоненты готовности учителя к осуществцению } \\
\text { экспериментально-исследовательской деятельности: }\end{array}$} \\
\hline $\begin{array}{l}\text { мотивационно- } \\
\text { цемевой }\end{array}$ & $\begin{array}{l}\text { содержательно- } \\
\text { технологический }\end{array}$ & $\begin{array}{c}\text { рефрлексивно- } \\
\text { прогностический }\end{array}$ \\
\hline \multicolumn{3}{|c|}{ Интегральные показатели компонентов: } \\
\hline $\begin{array}{l}\text { Потребность в осуще- } \\
\text { ствлении эксперимен- } \\
\text { тально- } \\
\text { исследовательской } \\
\text { деятельности. } \\
\text { Творческая самореа- } \\
\text { мизация учителя. } \\
\text { Целевая направлен- } \\
\text { ность собственной } \\
\text { экспериментально- } \\
\text { исследовательской } \\
\text { деятецьности. }\end{array}$ & $\begin{array}{l}\text { Знание основ теории } \\
\text { экспериментально- } \\
\text { исследовательской } \\
\text { деятельности. } \\
\text { Профессиональные } \\
\text { умения и навыки по } \\
\text { осуществцению экспе- } \\
\text { риментально- } \\
\text { исследоватемьской } \\
\text { деятельности. } \\
\text { Выработка индивиду- } \\
\text { ального стиля экспе- } \\
\text { риментально- } \\
\text { исследоватецьской } \\
\text { деятецьности. }\end{array}$ & 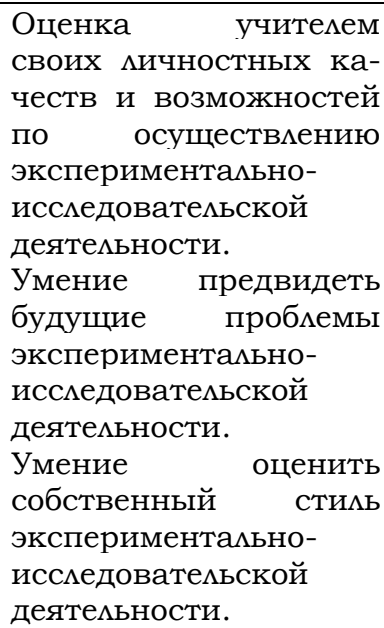 \\
\hline
\end{tabular}

Высокий уровень готовности учителя к экспериментальноисследовательской деятельности характеризуется:

- ярко выраженной потребностью и творческой самореали-

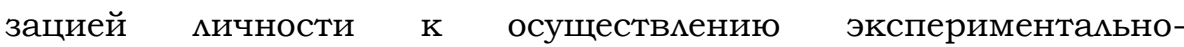
исследоватемьской деятемьности;

- высокой целевой направленностью собственной экспериментально-исследовательской деятельностью;

- глубокими и содержательными знаниями основ теории экспериментально-исследовательской деятельности, выработке индивидуального стиля экспериментально-исследовательской деятемьности; 
- умениями учителя оценить собственную профессиональнопедагогическую деятельность, прогнозировать и предвидеть будущие проблемы.

Педагоги, которые зачислены в группу достаточного уровня сформированности готовности к экспериментальноисследовательской деятельности:

- проявцяют желание к ее осуществцению, однако не всегда получают удовольствие от участия в ней;

- имеют достаточную целевую направленность собственной экспериментально-исследовательской деятельности;

- используют ситуативно, неупорядоченно знания, умения и навыки по осуществлению экспериментально-исследовательской деятельности, что задерживает выработку индивидуального сти$\Lambda я ;$

- обладают недостаточной выразительностью качеств педагогической рефмексии и прогнозируемости.

Категория педагогов, принадмежащая к среднему уровню сформированности готовности к экспериментальноисследовательской деятельности:

- проявляет интерес к участию в этом виде деятельности, однако не связывает ее с положительными изменениями в учебно-воспитательном процессе;

- имеет слабое проявление творческой самореализации и низкую целевую направиенность;

- обладает негцубокими теоретическими знания по организации и проведению экспериментально-исследовательской деятельности и низким уровнем профессиональных умений и навыков по ее осуществлению;

- демонстрирует низкое проявление умений по оценке мичностных качеств и предсказания будущих проблем экспериментально-исследовательской деятельности.

Педагоги, имеющие уровень сформированности готовности к экспериментально-исследовательской деятельности ниже среднего характеризуются:

- отсутствием интереса к участию в экспериментальноисследовательской деятельности;

- низкой творческой самореализацией и отсутствием целевой направценности; 
- низким уровнем вмадения знаний по основам теории экспериментально-исследовательской деятельности и неумением их использовать на практике;

- отсутствием качеств педагогической рефмексии и прогнозируемости.

Интегральные показатели и уровни готовности учителей экспериментальных учебных заведений к экспериментальноисследовательской деятельности раскрывают генезис мотивационно-целевого, содержательно-технологического и рефмексивнопрогностического компонентов профессиональной деятецьности педагогов. Определение уровня готовности учителей экспериментальных учебных заведений $\mathrm{k}$ экспериментальноисследовательской деятельности позволит спроектировать систему подготовки педагогических работников к этой деятемьности, обеспечить постоянный рост инновационного потенциала учитемей и уровня профессионального мастерства педагогов.

Итак, реализация диагностико-функционального направления в содержании научно-методической работы экспериментального учебного заведения обеспечивает изучение готовности учителей (педагогического комлектива) к экспериментальноисследовательской деятельности; способствует оказанию оперативной психологической помощи педагогическим работникам, в частности, в профилактике стрессовых состояний и синдрома "профессионального выгорания"; выявляет содержание, особенности развития инновационной образовательной среды в учебном заведении.

\section{References:}

1.Разина Н.А. Акмеологический подход к развитию профессионализма современного педагога в инновационной образовательной среде средней школы / Н.А. Разина // Вестник Научной школы педагогов „АКМЕ”. Акмеологическое моделирование профессионально-личностного развития педагогов: сборник научных статей [Текст] / под ред. М. И. Аукьяновой. - Уиьяновск: УИПКПРО, 2009. - Вып. 3. - С. 4-9.

2. Хацаюк Н.С. Зміст науково-методичної діяльності в експериментальних загальноосвітніх навчальних закладах / Н.С. Хацаюк // Вісник Ауганського національного університету 
імені Тараса Шевченка. Сер.: Педагогічні науки. Зб. наук. праць. - $\Lambda .:$ Видавництво Державний заклад „Ауганський національний університет імені Тараса Шевченка", 2012. - Ч. VII. - Вип. 22. C. $49-55$.

3. Шапран O.I. Створення інноваційного освітнього середовища в процесі професійної підготовки майбутнього вчителя / O.I. Шапран, Ю.П. Шапран // Педагогіка, психологія та медикобіологічні проблеми фізичного виховання і спорту. - 2010. - № 9. - C. $108-110$. 


\title{
INNOVATIVE ENVIRONMENT AS FACTOR OF ACTIVIZATION INNOVATIVE COMPONENTS OF PROFESSIONAL ACTIVITY OF FUTURE EXPERTS
}

\author{
Natalya Krasovska ${ }^{1}$ \\ 1. Assistant Chair of "Economics of Enterprise," Kerch State Maritime \\ Technological University, Ukraine.
}

\begin{abstract}
In work the five-factorial model of the equation of multiple regression is presented, is established that innovative activity of the country directly depends on science and education level of development; it is shown that qualitative and quantitative structure of experts directly causes formation of innovative capacity of the country.
\end{abstract}

Keywords: innovative potential, index of innovations, equations of multiple regression.

Введение. Одной из ключевых категорий, определяющих эффективность экономики, является формирование инновационной среды государства. Оценка степени развития инновационной среды определяет выявление потенциальных факторов, оказывающих влияние на реализацию инновационных приоритетов развития и оценка степени оказываемого воздействия на уровень инновационного развития.

Постановка проблемы. Анализ опыта развитых европейских стран свидетельствует, что главным элементом механизма формирования инновационного мидерства являются инновационные процессы в науке, производстве и образовании. Инвестиции в человеческий капитал создают благоприятные условия дмя повышения уровня знаний, совершенствования технологий и развития творческого потенциала. Однако на современном этапе экономического развития инновационному подходу к подготовке высококвалифицированных специалистов, в частности специамистов в области экономики, создающих необходимые условия для формирования инновационных профессиональных качеств и 
освоения новых экономических технологий, удемено недостаточное внимание. Такой подход обеспечит устойчивое экономическое развитие и укрепит позиции государства на мировом уровне, что обуславливает между тем, необходимость исследования факторов, оказывающих наибольшее вмияние на инновационный уровень развития страны с помощью математических и статистических методов и модемей.

Основные резумьтаты исследования. За последнее время понятие инновации стало более широким в своем значении. Спектр использования инноваций охватывает как новые и усовершенствованные продукты, так и новые организационные модели управленческих решений.

На рисунке 1 схематично представцена модель, описывающая взаимодействие факторных показателей, сводным критерием выбора которых является характеристика уровня развития образования и науки, а также результативность внедрения инноваций в экономику, которые оказывают влияние на изменение индекса инноваций (результативный показатель).

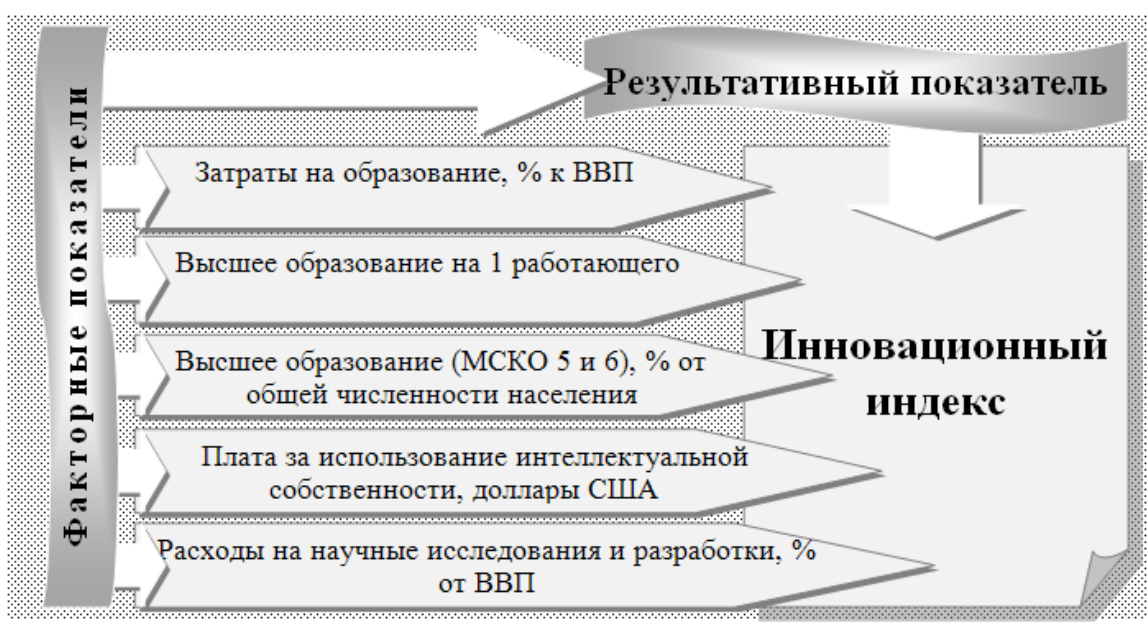

Рис. 1. Модель взаимодействия факторных показатемей и индекса инноваций

Инновационный индекс является крупнейшим и наиболее всеобъемлющим глобальным показателем, который детально характеризует инновационное развитие стран мира, находящихся на разных уровнях экономического развития. Данный показатель 
является комбинированным индикатором, характеризующим уровень взаимодействия науки и бизнеса и скорость внедрения научных разработок в экономику.

В таблице 1 представлены исходные данные дмя многофакторного корреляционно-регрессионного анализа, позволяющего оценить степень вцияния каждого из факторов на исследуемый результативный показатель.

Объединяющим детерминантом явцяется деятельность представленных стран в общеевропейском экономическом, политическом и образовательном пространстве, что объективно обуславливает допустимость сопоставцения представценных стран по уровню инновационного потенциала. Полученные параметры уравнения пятифакторной регрессии имеют следующий вид:

$$
\overline{Y_{x}}=42,8496+0,71943 \cdot X_{1}+12,066 \cdot X_{2}-0,15895 \cdot X_{3}+1,05188 \cdot X_{4}+5,001368 \cdot X_{5} \cdot(1)
$$

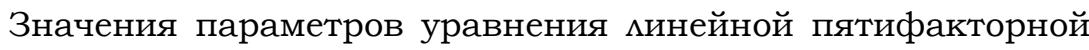
регрессии показывают, что с увеличением затрат на образование в общей структуре ВВП на 1 \%, индекс инноваций увеличивается на 0,71943 домей ед. Рост уровня образования на одного работающего демонстрирует увеличение индекса инноваций на 12,066 домей ед. Увемичение платы за использование интемлектуальной собственности и рост расходов на научные исследования приводит к увеличению индекса инноваций на 1,05188 и 5,001368 соответственно.

Однако, увеличение уровня охвата взрослого населения высшим образованием на 1 \%, приводит к снижению инновационного индекса на 0,15895 долей ед. Абсолютно оправдана и экономически обоснована обратная зависимость между уровнем охвата населения высшим образованием и инновационным индексом. Специфика данного показателя обусловлена промежуточным характером, и свидетельствует о готовности последующего перехода учащихся к профессии, требующей высоких профессиональных навыков. Дия краткосрочного периода данная динамика не носит показатецьного характера.

В таблице 2 представцена матрица значений парных коэффициентов минейной корреляции. 
Таблица 1

Факторы, опредемяющие инновационную активность европейских стран

\begin{tabular}{|c|c|c|c|c|c|c|}
\hline \multirow{2}{*}{ 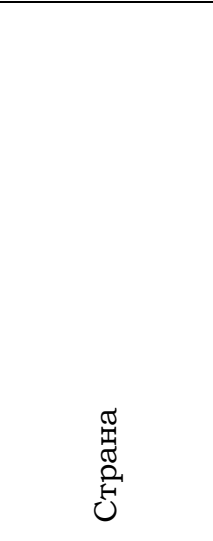 } & 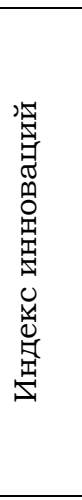 & 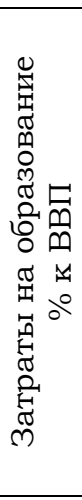 & 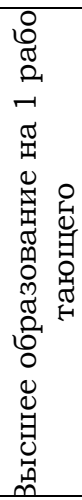 & 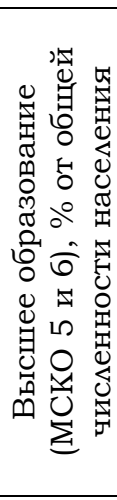 & 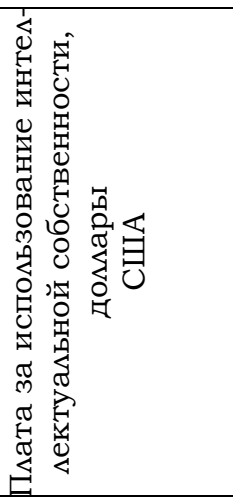 & 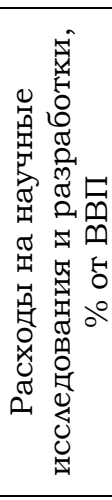 \\
\hline & $\mathrm{Y}$ & $\mathrm{X}_{1}$ & $\mathrm{X}_{2}$ & $\mathrm{X}_{3}$ & $\mathrm{X}_{4}$ & $\mathrm{X}_{5}$ \\
\hline Швеция & 64,8 & 6,6 & 0,8 & 73 & 6300885730 & 3,4 \\
\hline Финцяндия & 61,8 & 5,9 & 0,8 & 95 & 3187717775 & 3,88 \\
\hline $\begin{array}{c}\text { Великобри- } \\
\text { тания }\end{array}$ & 61,2 & 5,5 & 0,7 & 60 & 14082476426 & 1,76 \\
\hline Нидерланды & 60,5 & 5,3 & 0,8 & 65 & 5199537298 & 1,83 \\
\hline Дания & 59,9 & 7,8 & 0,6 & 74 & 2889560261 & 3,06 \\
\hline Аюксембург & 57,7 & 3,3 & 0,6 & 18 & 463374976 & 1,63 \\
\hline Эстония & 55,3 & 4,9 & 0,9 & 64 & 22642228 & 1,62 \\
\hline Бемьгия & 54,3 & 6,01 & 0,9 & 71 & 2562560261 & 1,99 \\
\hline Австрия & 53,1 & 5,4 & 0,5 & 70 & 779944457 & 2,75 \\
\hline Франция & 51,8 & 5,6 & 0,6 & 58 & 16127805584 & 2,25 \\
\hline Словения & 49,9 & 5,2 & 0,5 & 86 & 87594196 & 2,11 \\
\hline Чехия & 49,7 & 4,2 & 0,3 & 65 & 108268182 & 1,56 \\
\hline Испания & 47,2 & 4,3 & 0,8 & 83 & 1065080143 & 1,39 \\
\hline Аатвия & 47 & 5 & 0,6 & 57 & 10000000 & 0,8 \\
\hline
\end{tabular}

Источник: разработано автором по данным [1,2].

Значения парных коэффициентов корреляции меньше чем 0,85, это позволяет сделать вывод о целесообразности ввода факторов в одну корреляционную модель. Однако, значение коэффи- 
циента парной корреляции между высшим образованием (МСКО 5 и 6) и платой за использование интелмектуальной собственности, доммары США (-0,08459034), свидетельствует об обратной связи с незначительной степенью силы.

Таблица 2

Парные коэффициенты кинейной корреляции факторов, вкАюченных в уравнение пятифакторной регрессии

\begin{tabular}{|c|c|c|c|c|c|c|}
\hline \multirow{2}{*}{ 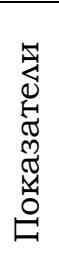 } & \multicolumn{6}{|c|}{ Значения коэффициентов парной корреляции } \\
\hline & $r_{Y X i}$ & $r_{X 1 X i}$ & $r_{X 2 X i}$ & $r_{X 3 X i}$ & $r_{X 4 X i}$ & $r_{X 5 X i}$ \\
\hline$Y$ & 1 & & & & & \\
\hline$X_{1}$ & 0,482729811 & 1 & & & & \\
\hline$X_{2}$ & 0,411797248 & 0,231273 & 1 & & & \\
\hline$X_{3}$ & $-0,011308837$ & 0,504662791 & 0,187277849 & & & \\
\hline$X_{4}$ & 0,343994512 & 0,294710384 & 0,122843977 & 0,08459034 & 1 & \\
\hline$X_{5}$ & 0,651169791 & 0,660482436 & 0,136519873 & 0,481017661 & 0,168357832 & 1 \\
\hline
\end{tabular}

Источник: разработано автором

Общее качество полученной многофакторной модели: ее достоверность по уровню значимости критерия Фишера, степень точности и надежности описания моделью процесса, подчеркивается соответствующими показателями, представценными на рис. 2 и табц. 3.

Коэффициенты регрессии (параметры уравнений) показали на сколько (в абсолютном выражении) в среднем изменяется резумьтативный признак при изменении факторного признака на единицу.

Степень точности описания моделью процесса влияния соответствующих факторов на значение индекса инноваций $(0,73)$ говорит о достаточно высокой степени точности (модель хорошо описывает процесс). Это означает, что представценными факторами можно объяснить 73 \% изменения индекса инноваций. 


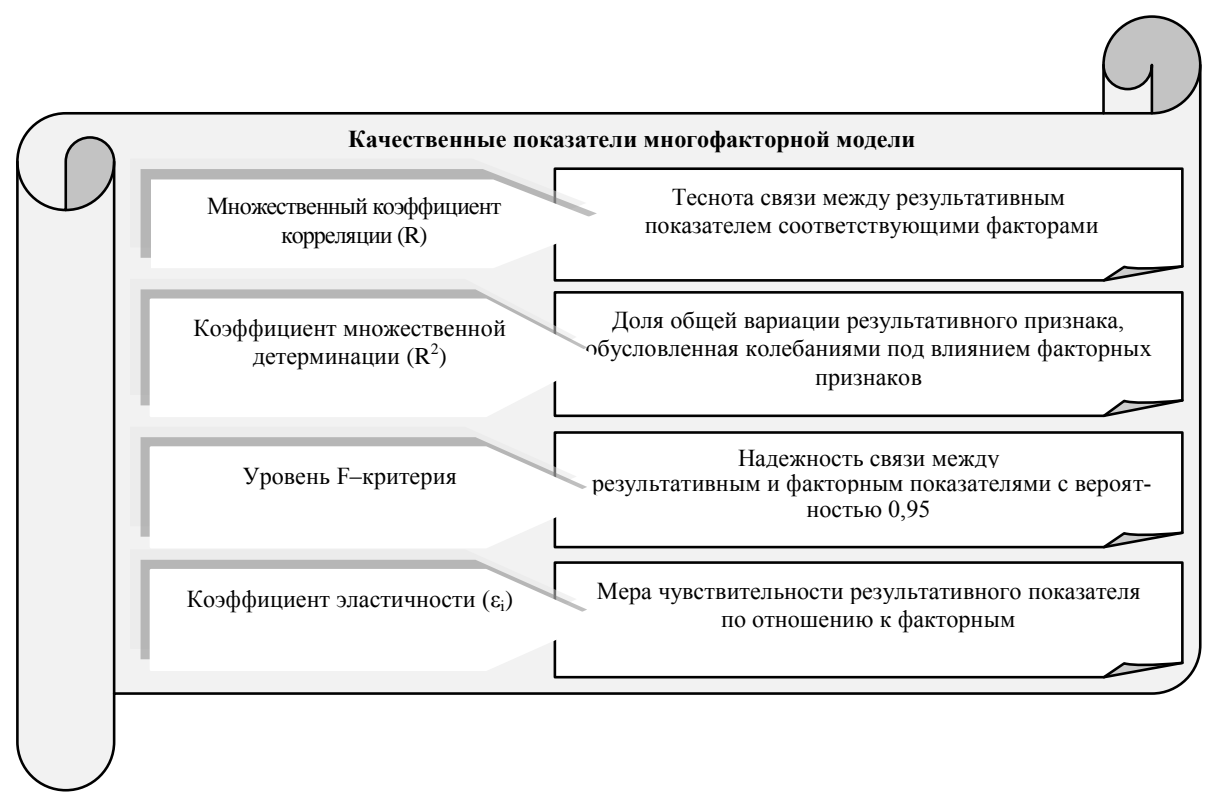

Рис. 2. Качественные показатели многофакторной модели

Таблица 3

Характеристики тесноты и надежности связи множественной Аинейной корреляции

\begin{tabular}{|l|l|}
\hline \multicolumn{1}{|c|}{ Показатеми } & \multicolumn{1}{c|}{ Значение } \\
\hline $\mathrm{R}$ & 0,854104371 \\
\hline $\mathrm{R}^{2}$ & 0,729494277 \\
\hline $\mathrm{F}_{\mathrm{\phi}}$ & 4,314847128 \\
\hline$F_{m}$ & 3,69 \\
\hline Значимость $\mathrm{F}$ & 0,0336 \\
\hline
\end{tabular}

Уровень F-фактического $(4,315)$ больше табличного $(3,69)$ с принятой степенью вероятности дает право утверждать о наличии влияния исследуемых факторов на индекс инноваций. Достоверность по уровню значимости критерия Фишера (Значимость F) значительно меньше 0,05, что подтверждает ее значимость.

Оценить степень количественного изменения индекса инноваций при изменении соответствующего фактора позволят частные коэффициенты эмастичности, значение которых не зависит от того, в каких единицах измеряются факторные показатели [3, 
c. 125]. Значения коэффициента эмастичности для соответствующих факторов приведены в таблице 4.

Согласно представленным данным, наибольшее влияние на коэффициент инноваций оказывают такие факторы как высшее образование на 1 работающего и расходы на научные исследования и разработки. Однако, следует отметить обратное влияние показателя высшего образования (МСКО 5 и 6), что подтверждает ранее сформулированные выводы.

Таблица 4

Показатели, характеризующие степень влияния отдельных факторов

\begin{tabular}{|l|l|}
\hline \multicolumn{1}{|c|}{ Факторы } & Значение \\
\hline Затраты на образование, \% к ВВП & 0,07 \\
\hline Высшее образование на 1 работающего & 0,147 \\
\hline Уровень МСКО 5 и 6, \% от общей численности населения & $-0,19$ \\
\hline $\begin{array}{l}\text { Плата за использование интемцектуальной собственности, } \\
\text { домары США }\end{array}$ & 0,007 \\
\hline Расходы на научные исследования и разработки, \% от ВВП & 0,194 \\
\hline
\end{tabular}

\section{Выводы.}

Таким образом, разработанная модель зависимости развития и результативности образования и науки на уровень инновационной активности государства, позволима выявить ключевые факторы динамичного инновационного роста государства. Что в свою очередь создает возможность повышения конкурентоспособности страны и актуализирует необходимость увеличения значимости человеческого фактора в инновационном процессе.

\section{References:}

1. GNI per capita, Atlas method (current US\$). [Electronic resource]. - 2013. - Access mode: http://data.worldbank.org/ indicator/NY.GNP.PCAP.CD

2. Population, total refers to the total population. [Electronic resource]. - 2013. - Access mode: http://data.worldbank.org/ indicator/SP.POP.TOTL?display=default

3. Яркіна Н.М. Статистика: навчальний посібник / Н.М. Яркіна. - К. : Університет "Україна», 2012. - 260 с. 
4. Аогунова Н.А. Экономика и организация инновационной

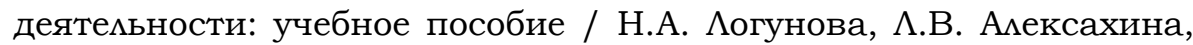
Н.А. Красовская. - К. : Из-во «Кондор», 2013. - 273 


\title{
DIDAKTOGENIYA: CONCEPT DEFINITION
}

\author{
Natalia Niyazbaeva ${ }^{1}$
}

1. Candidate of Pedagogical Sciences, Associate Professor, Kostanai State University im. A. Baytursynov, Kazakhstan.

In article are considered the concept "didaktogeniye"; didaktogeniya interpretation as forms of neurosis of the child called by destructive actions of the teacher is presented. Didaktogeniya manifestations are considered: destructive active and passive psychological reactions, alienation, destructive behavior of the child.

Keywords: didaktogeniye, neurosis, alienation, the destructive behavior, the helping relations.

Термин "дидактогения" был введён вслед за термином "ятрогения" [О. Бумке, 1925]. Ятрогения - психическая травма, причиняемая врачом. В современной медицинской митературе употребмяют также понятие "ятропатии" как отрицательные для больного действия врача, но не психологического, а физического порядка. В словарно-справочной митературе отмечается, если ятрогения категория психогенных состояний хорошо исследована в медицине [Р.А. Аурия (1944г.), И. Харди (1973 г.)], то в педагогической и психологической практике и специальной цитературе проблемы дидактогении почти не представлены, за исключением терминомогических словарных опредемений [3; 4].

Поисковая система Mail.ru дает больше двухсот ссылок по запросу "дидактогения". В подавцяющем большинстве источников понятие "дидактогения" рассматривается синонимично с "дидактогенным неврозом". В словарях, дидактогения (от греч. didaktikos "поучающий", и -genes-"рождающий, рождённый") - это негативное психическое состояние учащегося, вызванное нарушением педагогического такта со стороны педагога [3]. Психологически выражается в фрустрации, страхе, подавленном настроении, тревожности и т.п. Отрицательно сказывается на продуктивности учебной деятельности учащегося, коммуникативных отношениях со всеми участниками педагогического процесса. 
В педагогике проблемы дидактогении рассматривал И.П. Подласый, опредемяя ее как действие участника педагогического процесса, приводящее к отрицательной эффективности дия обучающегося, а также и сам этот эффект [5].

В основе возникновения дидактогении межит психическая травма, полученная учеником по вине педагога. Грубые слова, насмешки, деструктивная критика поведения учеников, бестактные замечания, большое их количество, несправедиивые отметки и высказывания, высокомерие по отношению к ребенку - ошибки непрофессионалов, которые, к сожалению, не редкость в наших школах и вузах. Огромное количество ситуаций, от которых у детей дрожь в руках, недержание мочи, раздражительность, повышение температуры, головные боли и т.д.

Сама по себе дидактогения - это форма невроза, но невроза на границе нормы и нарушения. Впрочем, в международной системе болезней школьная фобия входит в систему заболеваний, поясняет А. Прихожан [6].

Но в то же время исследователи выделяют дидактогенный невроз (Н. Жутикова, А.Б. Соколова, С.С. Хапаева и др.) как нервно-психическое расстройство мичности ребенка, основной причиной которого является нарушение значимых дмя него отношений в диаде "учитель-ученик". Невроз понимается здесь не в медицинском плане, а скорее как неадекватный способ реагирования на те или иные сложности в школьной жизни. Как правило, школьные неврозы проявляются в беспричинной агрессивности, боязни ходить в школу, отказе посещать уроки, отвечать у доски, т.е. отклоняющемся, дезадаптивном поведении. Чаще наблюдается состояние школьной тревожности, которая выражается в во нении, повышенном беспокойстве в учебных ситуациях, в классе, ожидании пцохого отношения к себе, отрицательной оценки со стороны педагогов, сверстников.

Реакции ребенка на чуждые отношения с учителем могут проявцяться в активной и пассивной формах. Пассивные реакции выражаются в замкнутости, закрытости, скупости чувств, низкой самооценке, страдании, отчаянии, одиночестве, обособменности, безразличии, отстраненности, изоляции. Активные реакции выражаются в агрессивности, гневе, ненависти, открытой конфронтации, физическом сопротивцении, грубости, конфциктах, "бунтах". Философы проявцения подобных реакций называют 
отчуждением; быть отчужденным - значит быть беспомощным, неспособным активно воздействовать на окружающий мир, на

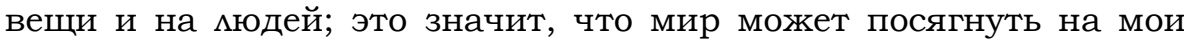
права, а я не могу защититься, - пишет Э. Фромм [8, с. 114].

Активной формой отчуждения человека Э. Фромм называет деструктивность личности как "извращение жизненного импульса, энергия неизжитой жизни, трансформированная в энергию, направленную на разру-шение жизни" [9, с. 111]. Импульс к разрушению других, по мнению фимософа, проистекает из страха быть разрушенным ими. Деструктивность являяется результатом "более интенсивной и более полной блокировки плодотворности, чем отстраненность" [9, с. 111].

Деструктивное поведение ребенка - это наиболее активная реакция отчуждения, характеризующая в целом все разрушительные действия чемовека.

В общем значении, деструктивный (от мат. destructivius) разруши-тельный, нарушающий нормальную структуру чегомибо. Деструктивность в психологии - разрушительные механизмы человеческой психики; форма неосознаваемого саморазрушительного поведения человека. В психоло-гических теориях деструктивного поведения представмены две позиции: 1) деструктивность может быть спонтанной и связанной со структурой Аичности [Э. Фромм]; 2) деструктивное поведение - это всегда производная вторичная реакция, некой изначальной деструктивности Аичности нет [А. Маслоу], что подразумевает, что деструктивное поведение ребенка в школе является следствием разрушающего, деструктивного по отношению к данному ребенку поведения педагога.

Занимаясь проблемами школьной тревожности и школьных страхов, А.Прихожан уточняет, что случаи дидактогении пцохо фиксируются. Только в крайнем случае, когда ребенок уже попал в больницу с настоящим неврозом. Это 1-2\% детей. Обычно взрослые не придают должного значения состоянию ребенка, говорит психолог в одном из интервью, - повысилась температура, оставили дома, а к вечеру уже все прошло. Родители могут не узнать о решении ребенка не ходить в школу. Есть и такие факты: ребенок набирает полную грудь воздуха и, преодолевая ужас, все-таки входит в класс. Взрослые не подозревают о его страданиях [6]. 
Международная статистика по всем видам школьных страхов: $10-15 \%$ детей. На территории постсоветского пространства, этот процент намного достигает 40\% [6].

Исследования в школах показывают, что около $30 \%$ детей обладают неуравновешенной психикой и нуждаются в специальной психологической помощи [2]. Известный детский врач С.Я. Долецкий ввел в научный оборот специальный термин - синдром опасного обращения с детьми (СООСД). Медики утверждают, что есть заболевания детей, вызванные характером обращения с ними учителей [4].

Собственный практический опыт автора, а также сведения из митературы позволяют считать, что учительская профессия это труд, который нередко создаёт ситуацию хронического стресса. Достаточное большое работает учителей с различными формами неврозов. По данным доктора педагогических наук В.И. Петрушина до $70 \%$ учителей страдают невротическими расстройствами [4].

Но мишь помогаюшие отношения [К. Роджерс], о которых уместно вспомнить в контексте обозначенной проблемы, есть источник здоровья, активности, уверенности человека, веры в собственные силы и возможности, развития уникальности, преодомения неврозов, школьных трудностей ребенка, проявления его творчества. В таких взаимоотношениях происходит изменение маленького человека и в его мыслях, и в поведении, и на сознательном уровне, и на более глубоком, внутреннем, что дает ему возможность справиться со всеми другими трудностями в школе более конструктивным, разумным способом, приносящим удовольствие от общения с учителем.

\section{References:}

1. Жутикова Н.В. Психологическая наука - школе. М., 1988.

2. Кодохмаева Ф.А. Дидактогения [Эмектронный ресурс] Режим доступа: http://festival. 1 september.ru/articles/314022/.

3. Краткий психологический словарь. - Ростов-на-Дону: "ФЕНИКС". А.А.Карпенко, А.В.Петровский, М.Г. Ярошевский. 1998. 
4. Медведева А.А. К вопросу о дидактогенном неврозе [Эцектронный ресурс] - Режим доступа: http://visnyk.com.ua/stattya/ 2832-k-voprosu-o-didaktogennom-nevroze.html.

5. Подмасый И.П. Курс мекций по коррекционной педагогике. Для средних специальных учебных заведений. М.: Владос, 2002.

6. Прихожан А. "Но самое страшное место - у доски" // Первое сентября. 2005. №.38.

7. Шевелева В.С. Школьные, дидактогенные неврозы и другие психические реакции [Электронный ресурс] - Режим доступа: http://www.openclass.ru/stories/50347.

8. Фромм Эрих. Душа человека: Перевод. М.: Республика, 1992.

9. Фромм Э. Человек для себя. Мн.: «Комлегиум», 1992. 


\title{
APPLICATION OF INTERACTIVE METHODS OF TRAINING, AS A CONDITION OF INCREASE OF MOTIVATION OF STUDENTS TO DISCIPLINE STUDYING "PHILOSOPHY AND EDUCATION HISTORY"
}

\author{
Madina Gamzaeva ${ }^{1}$
}

\section{Candidate of Pedagogical Sciences, Associate Professor, Dagestan state pedagogical university, Russia.}

\section{Abstract}

The article reveals the essence of interactive teaching methods in the preparation of future teachers. As well as the stages of work in the classroom on the philosophy and history of education. The role of interactive teaching methods as one of the conditions to increase the motivation to study subjects.

Keywords: interactive teaching methods, teachers, students, motivation.

Мотивация представцяет собой важный аспект мичности, на котором замыкаются такие её качественные характеристики, как смысложизненные ценности, цели, направленность, воля. В роли мотивов могут выступать эмоции, идеалы, установки, потребности, влечения, интересы. Без домжной мотивации учебная деятельность превращается в формальный процесс, источник психических травм и комплексов.

Высокой мотивации студентов к образованию можно добиться, создавая в ходе обучения ситуацию успеха дмя каждого обучающегося, сопряжённую с повышением интереса к изучению предмета и ростом их потребности к познанию. Таким требованиям отвечают современные интерактивные методы обучения, в основе которых межит совместная познавательная деятельность преподавателя и студента.

Под интерактивными методами понимается система правиц взаимодействия преподавателя и студента в форме учебных игр и ситуаций, обеспечивающая педагогически эффективное познавательное общение. 
Интерактивные методы обучения создают дидактические условия дмя переживания учащимися ситуации успеха в процессе учебной деятельности. Они реализуют творческий потенциал студентов, активизируют их познавательную активность.

Интерактивное обучение определяет способы продуктивного, критического осмысления информации. В первую очередь, оно даёт простор дмя использования размичных модемей, знаковых систем, помогающих определённым образом структурировать большой поток информации, выделяя необходимое для активного пользования. Содержание учебного материала по истории включает множество различных видов знаний, что во многом опредемяет сложность и противоречивость его понимания и усвоения студентами на разных этапах обучения. Уже по этой причине это прекрасная основа дия творческого использования интерактивных методов обучения, определяющих успех и развитие мотивации у студентов. Важно, что интерактивные формы занятий основаны на самостоятельной работе с различными видами исторической информации, на разнообразных приёмах сбора, обработки и презентации результатов своей творческой поисковой деятельности, на вариативности способов коммуникации в учебных группах.

При использовании интерактивных методов обучения отношения между преподавателем и студентом должны основываться на принципах доверия, доброжелательности, партнерства, взаимопонимания, взаимовыручки и поддержки, терпимости, учета и уважения интересов, возможностей друг друга. Основой деятельности преподавателя в условиях интерактивного обучения является Аичностно-ориентированный подход, который требует соблюдения гуманной педагогической позиции, ценностного отношения к обучающемуся, его творчеству, создания культурноинформационной и предметно-развивающей среды, владения методикой и основами образовательной технологии. В процессе организации, управления и контроля за развитием интерактивного общения между студентами преподаватель преимущественно использует косвенные приемы педагогической деятельности, предоставляя обучающимся самостоятельность в выборе средств достижения цели, адекватных учебных действий, партнеров. Он мишь организует учебную деятельность, управляет ею, корректи- 
рует по необходимости и оценивает (часто с помощью самих обучающихся).

Наиболее эффективным способом организации занятий с применением интерактивных форм и методов обучения явмяется коммективный способ организации занятий, который в большей степени отвечает задачам интерактивной деятельности обучаемых.

Основным признаком групповых форм занятий явцяется общность учебной ситуации, когда все обучающиеся класса выполняют одно и то же задание за определенный промежуток времени, одним и тем же способом и одинаковыми средствами. Второй признак групповых занятий - одинаковый маршрут освоения учебной программы, подразумевающий единство последовательности изучения разделов, тем учебного материала.

Вопросы и задания, которые предмагаются дмя изучения, обсуждения обучающимся, непременно должны быть проблемного, исследовательского, развивающего и творческого характера, разного уровня трудности и сложности. Репродуктивные вопросы в этом случае неэффективны.

Примерные этапы интерактивной работы: этап подготовки педагога и учащихся к интерактивному обучению; этап комплектования групп; этап учебной деятельности обучающихся в группе; этап презентации группового решения; этап экспертизы (на усмотрение преподавателя); этап рефмексии прошедшего занятия.

Мы используем интерактивные методы на занятиях по "Фимософии и истории образования" в виде:

1. Уроков с применением кейс-технологии. Преимущество данной техноцогии состоит в том, что обучающимся предоставцяется возможность погрузиться в конкретную ситуацию, осознать себя участником каких-либо исторических событий, встать на чью-цибо позицию. Наиболее эффективно данная технология применяется на уроках, где необходимо рассмотреть конкретные события, взгляды, мнения (нпр. при изучение таких тем: «Педагогические идеи Ж.-Ж. Руссо", "Школа и педагогическая мысль в эпоху Возрождения" и др.).

Путешествие в другое время. Представьте, что у вас есть

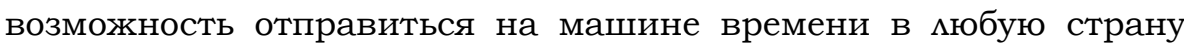
средневековья. Составьте программу полета: Укажите век (год), в который вам хотелось бы перенестись. 
Назовите страну, которую вы хотели бы посетить.

Выберите, в роли какого ученого-педагога вам хотелось бы находиться во время путешествия и т.д.

Обоснуйте ваш выбор века (года), страны и роли. Определите цель вашего путешествия. По окончании путешествия составьте план-отчет. В зависимости от цели путешествия вкцючите в него описание внешнего вида мюдей, орудий труда, оружия, а также архитектурных памятников, произведений искусства; характеристику выдающихся исторических мичностей; беседы с мюдьми этой эпохи. Как правимо, студенты с интересом воспринимают подобные задания. Описание типичных эпизодов или введение в рассказ диалогов не вызывают у них затруднений.

2. Уроков с применением технологии "Аквариум". Данная технология очень эффективна при изучении спорных вопросов истории педагогики, поскоцьку она позволяет создать ситуацию дебатов, когда обучающиеся не только занимают определенную позицию по спорному вопросу, но и отстаивают ее друг перед другом, убеждают в своей правоте.

3. Уроков с применением игровой технологии. В этом случае обучающиеся также могут поставить себя на место определенных ученых-педагогов, «прожить" какую-либо ситуацию.

Данная технология эффективна, когда необходимо воссоздать какую-цибо деятельность, поступки конкретной историче-

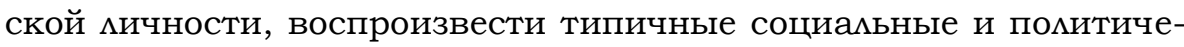
ские ситуации в концентрированном виде. В ходе игровой деятельности даже ученики в большинстве случаев не принимающие активного участия в ходе занятия, но желающие получить знания в готовом виде, с удовольствием вкцючаются в процесс поиска информации и ответов.

4. Уроков с применением технологии развития критического мышления. Данная технология позволяет глубоко осмыслить информацию, "пропустить через себя", выработать определенное отношение к ней, поэтому ее уместно применят на занятиях при изучении трудов ученых-педагогов.

5. Уроков с применением ИКТ. Поле деятельности с применением данной технологии обширно, поэтому ее можно применять буквально на всех занятиях. Это уроки с использованием мультимедиа презентаций (при изучении нового материала, за- 
щита проектов обучающихся), уроки компьютерной поддержкой (проектная деятельность студентов, проверка знаний).

Мотивацию обучающихся необходимо использовать, чтобы учебная деятельность не превратилась в формальный процесс. Находить способы мотивации нужно учитывая требования и возможности сегодняшнего дня. Пришло время, когда обучающемуся не только необходимо, но и интересно использовать интерактивные технологии в процессе образования, и это обстоятельство должен использовать педагог дмя достижения наиболее высоких результатов. В современном обществе, где одним из важных этапов социализации являются не только знания, а еще и умение их применять в практической деятельности, вуз должен учитывать все возможности и достоинства интерактивных методов обучения, а значит идти в ногу со временем.

В вузе начинают формироваться и развиваться такие ключевые компетентности, как информационная, коммуникативная, проблемная, кооперативная, а помогают в этом процессе интерактивные методы обучения. Это приводит к высоким образовательным результатам, удовлетворенности своей деятельностью, как преподавателя, так и студентов. И если студент цегко выполняет свою работу, проявцяет заинтересованность, удовцетворен ее результатами, то и мотивация к изучению такого предмета у него значительно вырастает. Поэтому одним из передовых способов повышения мотивации к изучению "Философии и истории образования" является применение интерактивных методов обучения.

Рассмотренные в настоящей статье интерактивные методы обучения и образовательные технологии направлены, прежде всего, на повышение собственной активности студентов и их мотивации к учебно-профессиональной деятельности. Они позволяют перейти к их активному применению в модельных или реальных ситуациях профессиональной деятельности, что, безусловно, повышает качество подготовки будущих специалистов.

\section{References:}

1. Аронова Г.А. Методика обучения взрослых: особенности мекционной формы подачи материала по гуманитарным дисципминам [Эмектронный ресурс] // Фестиваль педагогических идей 
"Открытый урок": [сайт]. - 2012. - Режим доступа: http://festival.1september.ru/articles/513950/

2. Ситуационный анализ, или Анатомия Кейс-метода / под ред. Ю.П. Сурмина. Киев: Центр инноваций и развития, 2002. 286 c.

3. Современные образовательные технологии: учебное пособие / под ред. Н.В. Бордовской. 2-е изд., стер. М.: КНОРУС, 2011. $432 \mathrm{c}$

4..Ступина С.Б. Технологии интерактивного обучения в высшей школе: учебно-методическое пособие. Саратов: Издательский центр «Наука", 2009. 52 с. 


\title{
THE ETHNIC REPRESENTATIONS OF YOUNGER SCHOOLBOYS
}

\author{
Soelma Dagbaeva ${ }^{1} \&$ Tanya Volozhaninova ${ }^{2}$ \\ 1. Candidate of Psychology Sciences, Docent lecturer of chair \\ of psychology of formation, \\ Transbaikalian state university, Russia.
}

2. Student, Transbaikalian state university, Russia.

\begin{abstract}
Article is devoted ethnic representations of younger schoolboys. In consciousness of each person the special place occupies its relation to the national identity and the relation to representatives of other nationalities, ethnos. For each person during the separate moments of life there can be sharply actual an interaction at level of international relations. Dialogue of representatives different ethnic obshchnostej - is rather difficult psychological problem. For each person there is its national consciousness and the relation which has developed in culture to representatives of other nations.
\end{abstract}

Keywords: ethnic identity, ethnic awareness, social space, ethnic culture.

Среда развития современного ребенка, являясь многонациональной, создает возможности разнообразных контактов с артефактами иных культур, с особенностями представителей других национальных групп, что требует понимания этнопсихологических сходств и размичий закрепляющихся в представлениях и стереотипах.

Дети, с одной стороны, окружены большим количеством доступной и порой противоречивой информации о других этнических группах. С другой стороны, отсутствие или недостаточность знаний о мультикультурной среде, привычках и традициях, нормах поведения и ценностях в современном обществе настолько требует осмысления складывающихся у дошкольников, школь- 
ников и подростков представцений об особенностях разных этносов, разАичий и сходств между ними [1, с. 62].

Дия каждого человека этническая идентичность означает осознание им своей принадмежности к определенной этнической общности. С ее помощью человек солидаризуется с идеалами и стандартами своего этноса и разделяет другие народы на похожих и непохожих на свой этнос. В итоге выявцяется и осознается уникальность и неповторимость своего этноса, его культуры.

Этническая идентичность - это осознание, восприятие, эмоциональное оценивание, переживание своей принадлежности к этнической общности. Смысл данного понятия наилучшим образом отражает именно термин переживание, переживание индивидом отношений Я и этнической среды своего тождества с одной этнической общностью и отдаление от других общностей, самоопределения в социальном пространстве относительно многих этносов [3, с. 74].

Социальное пространство в современной жизни мюдей не очерчено однозначными правимами и обязанностями, оно обусловлено многими составляющими, которые не доступны ребенку. Это провозглашаемая или подразумеваемая идеология государства, традиционные нормативы, нравственные требования религий, реалии межэтнических и реалии экономических отношений мюдей, естественноисторическая нестабильность правовых и моральных критериев. Безусловно, столь сложная система зависимостей, обязанностей и свобод находится за предемами самосознания ребенка младшего школьного возраста.

Если ребенок воспитывается в религиозной семье, он осваивает нормативность и ценности религиозных отношений и движения духа к самосовершенствованию. В регионах совместного проживания представителей разных этносов ребенок очень рано присваивает стиль межэтнических отношений; у него формируется глубинно присущая ему эмоциональная позиция по отношению к своему и другому этносу, проживающему в едином геоисторическом пространстве [1, с. 49].

Первоначально этническая осведомленность основывается на очевидных показателях - внешности, языке, элементах материальной культуры (одежде, еде), обычаях. Постепенно повышается способность ребенка воспринимать, описывать, интерпретировать этнические признаки. Он включает их в комплекс все но- 
вых элементов - общность предков, общность исторической судьбы, религию. В младшем школьном возрасте происходит перестройка отношений ребенка с мюдьми. Закладывается фундамент всестороннего развития мичности, формируется ее базовая кумьтура, воспитывается добросовестное отношение к учению, общественно- полезному труду, Аюбовь к Родине, к своему народу. Овмадение этнической культурой в начальной школе способствует развитию у детей чувств национальной гордости и национального достоинства, патриотизма, что в конечном счете ведет к становмению этнической идентичности младших школьников. Дети мкадшего школьного возраста должны знать родной язык, иметь представления о традиционной пище, знать произведения устного народного творчества, народные традиции, обычаи и обряды, народные праздники и другое [3, с. 115].

Основываясь на теоретическом анализе проблемы, мы провели эмпирическое исследование этнических представлений учащихся 2-3 классов МОУ СОШ №3 г.Читы; общее число испытуемых 54 человека из них (32 девочки и 22 мальчика), средний возраст испытуемых 8-9 мет.

В рамках данного исследования нами использовалась методика полуструктурированного интервью (Романова О. $\Lambda$ ) [2, с. 15] Респондентам предъявлялся Аист с вопросами, в котором вопросы были направлены на выяснения отношения респондента к исторической судьбе своего народа, выявляющие присущее ему чувство "родной земли" (представление об этнической территории), определяющие его отношение к этнодифференцирующим признакам (языку, верованиям, одежде, пище, быту).

Результаты исследования показали, что есть дети (15\%) не знающие свою этническую принадлежность; $11 \%$ детей не знают чем отличаются мюди разных национальностей; $15 \%$ детей не знают, кто их родители по национальности; 9\% детей путают национальные праздники с международными; 26\% детей не имеют представления, что они живут в России; $15 \%$ детей не совсем представляют свою национальность.

Таким образом, этнические знания ребенка 8-9 мет нестабильны и несистематичные: дети не всегда могут назвать собственную национальность, национальность родителей, путают названия национальностей, городов. Слабость этнических знаний в значительной степени определяется отсутствием должного уровня 
развития познавательных процессов, которые позволили бы ребенку понять всю сложность и многоаспектность явлений этнической жизни. Дети 8-9 мет с большим трудом представляют себе социальную действительность: они могут говорить о различиях языков - но не о размичиях культур, исторических путей развития этнических групп; они могут заметить размичия в одежде- но не в системах национальных обрядов, обычаев, традиций.

\section{References:}

1. Стефаненко Т.Г. Этнопсихология Г.Г. Шпета в XX в.// Психологический журнал, №3, 2009. С. 106-116.

2. Стефаненко Т.Г. Этнопсихология: практикум: Учеб. пособие дия студентов вузов. М.: Аспект пресс, 2008. 208 с.

3. Хотинец В.Ю. Этническая идентичность и толерантность. Екатеринбург: Изд-во Урал, ун- та, 2004. 121 с. 


\section{B\&M Publishing}

Pedagogical and psychological problems of the modern society: scientific approaches to the study and overcoming practices: research articles, B\&M Publishing, San Francisco, California. 2014. 116 pp.

PQN 100

ISBN-10:0991517164

ISBN-13:978-0-9915171-6-9 